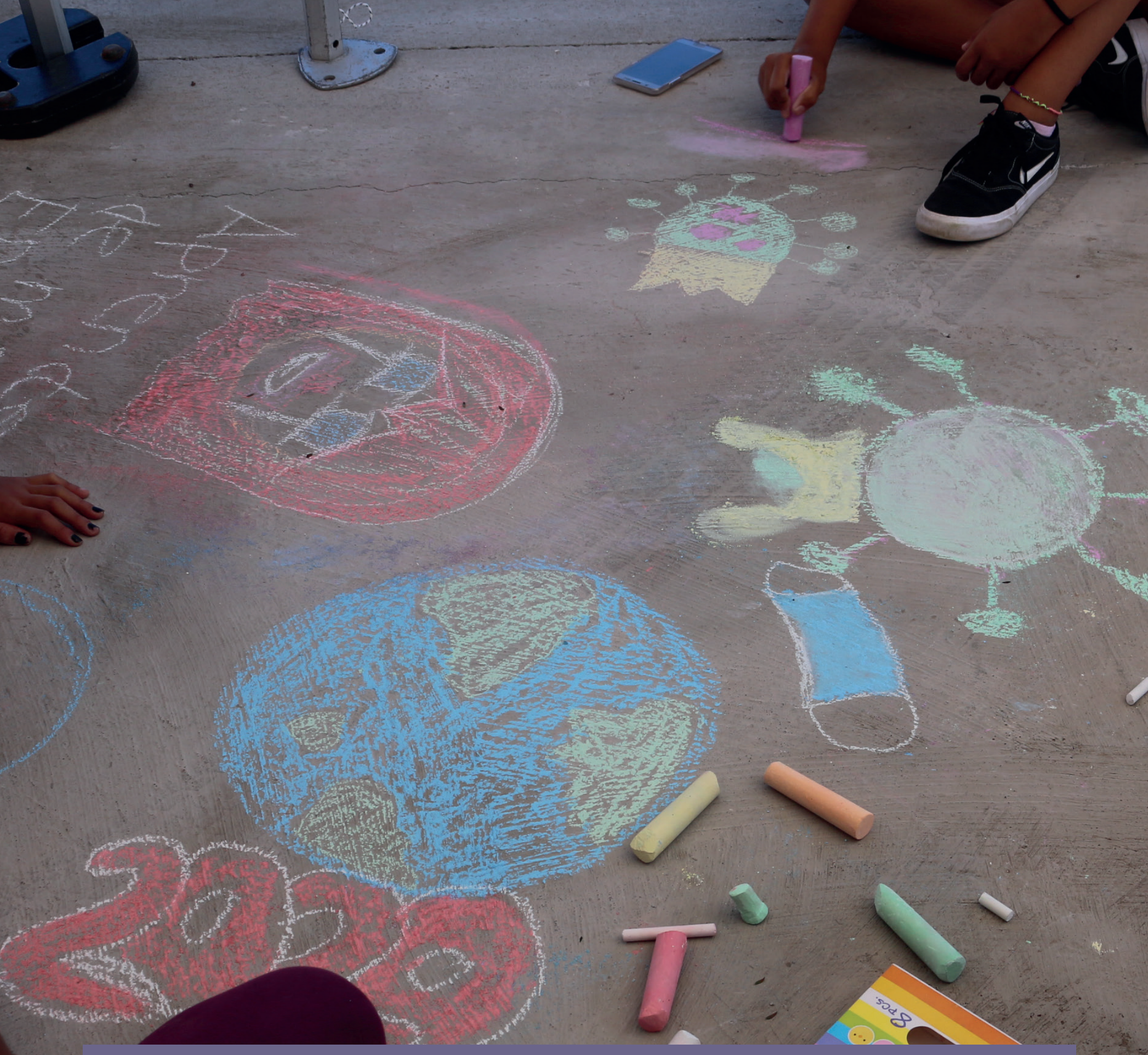

\title{
Monografía Comunitaria La COVID-19 en San Cristóbal de La Laguna: una mirada desde la comunidad
}



"La sociedad se fortalece cuando se encuentra unida, cuando podemos tender una mano a nuestro vecino sin recibir nada a cambio. Nos ha hecho ver el mundo de forma diferente" 
Coordinación Alexis Mesa Marrero

Vicente Manuel Zapata Hernández

Equipo de redacción Alejandro Darias Abreu

Alicia Morales Pereyra-García

Basilio Valladares Hernández

Carla Ramos Afonso

Carlos Flores Rodríguez

Edu González Pérez

Gracy Carolina Velasco Gavilánez

Jennifer Moreno Jorge

Julio César Castañeda Nuñez

Justo Ayoset Miranda Domínguez

Laura Esther Darias Domínguez

Luz María Morín Ramírez

Naira Perera Alberto

Noelia Jorge Jiménez

Patricia Verstraete Déniz

Rina Zoraida Castro Arellano

Silvia Ascanio Gómez

Verónica Antonieta Pascual Marichal

Ilustraciones Victor García Seoane

(victorgiaseaone@gmail.com)

Edición Iris Pérez González

(iris.perez.glez@gmail.com)

\section{Monografía Comunitaria "La COVID-19 en San Cristóbal de La Laguna: una mirada desde la comunidad"}

Depósito Legal: TF 325-2021

DOI: https://doi.org/10.25145/b.Com.COVID19.LaLaguna.2021

Se permite la reproducción total o parcial de esta obra por cualquier procedimiento, siempre y cuando se cite su autoría.

El proyecto Comunidad ha contado con la colaboración del Área de Acción Social, Participación Ciudadana y Diversidad del Excmo. Cabildo Insular de Tenerife. 



\section{Índice}

Introducción

Metodología

Un año de COVID-19: La información objetiva 17

El contexto geodemográfico del municipio de San Cristóbal de La Laguna 18

Crecimiento de la población municipal y distrital entre 2010 y 2020

Estructura de la población de San Cristóbal de La Laguna y sus distritos 23

Población según lugar de nacimiento y principales procedencias en

San Cristóbal de La Laguna y sus distritos

EI SARS-CoV-2 y la evolución epidemiológica de la COVID-19 en

San Cristóbal de La Laguna

El diagnóstico $\quad 27$

La trasmisión $\quad 27$

El tratamiento 28

Las vacunas 28

La COVID-19 en San Cristóbal de La Laguna 28

Normativa y medidas de prevención en San Cristóbal de La Laguna:

Un año de restricciones

Normativa a nivel estatal: centralizando las decisiones 33

Normativa a nivel autonómico: concretando el estado de alarma 37

Normativa a nivel insular: del Cabildo al Ayuntamiento

La mirada de la comunidad: la información subjetiva 43

Impactos en el municipio $\quad \mathbf{4 5}$

Impactos negativos $\quad 46$

Sociedad 48

Economía 50

Salud $\quad 52$

Educación $\quad 54$

Empleo 56

Ocio 57

Servicios Sociales $\quad 57$

Espacios Públicos

Impactos positivos $\quad \mathbf{5 9}$

Sociedad 60

Salud 61

Educación $\quad 62$ 
Iniciativas desarrolladas $\quad 64$

Ciudadanía 66

Recursos técnicos 67

Administración 68

$\begin{array}{ll}\text { Expectativas de futuro } & 70\end{array}$

Expectativas positivas $\quad \mathbf{7 2}$

Sociedad $\quad 73$

Salud $\quad 73$

Expectativas negativas $\quad \mathbf{7 4}$

Sociedad $\quad 75$

Economía $\quad 75$

$\begin{array}{ll}\text { Aprendizajes y conflictos } & 76\end{array}$

$\begin{array}{ll}\text { Conflictos } & \mathbf{7 9}\end{array}$

Conflicto social $\quad 80$

Conflicto profesional $\quad 81$

Conflicto personal $\quad 82$

$\begin{array}{ll}\text { Aprendizaje } & \mathbf{8 2}\end{array}$

Aprendizaje profesional $\quad 85$

Aprendizaje social $\quad 86$

Aprendizaje personal 86

$\begin{array}{ll}\text { Propuestas de mejora } & \mathbf{8 7}\end{array}$

Sociedad $\quad 88$

Salud $\quad 90$

Educación $\quad 92$

Servicios Sociales $\quad 96$

Espacios públicos $\quad 98$

Economía 100

$\begin{array}{ll}\text { Ocio } & 102\end{array}$

Empleo 104

Cultura 106

Seguridad Ciudadana $\quad 107$

Deporte 108

$\begin{array}{ll}\text { Conclusiones } & 109\end{array}$

\section{Glosario}

Anexo I. Esquema de síntesis

Anexo II Carta de servicios municipales

Anexo III Catálogo de Iniciativas Ciudadanas

Anexo IV Relación de Bandos Municipales

Anexo V. Fichero Comunitario

Anexo VI. El proceso de audición: anatomía de una técnica de investigación participativa.

Anexo VII. Estadísticas y relación de personas/entidades escuchadas en el Proceso de Audición

Anexo VIII. Testimonios seleccionados 


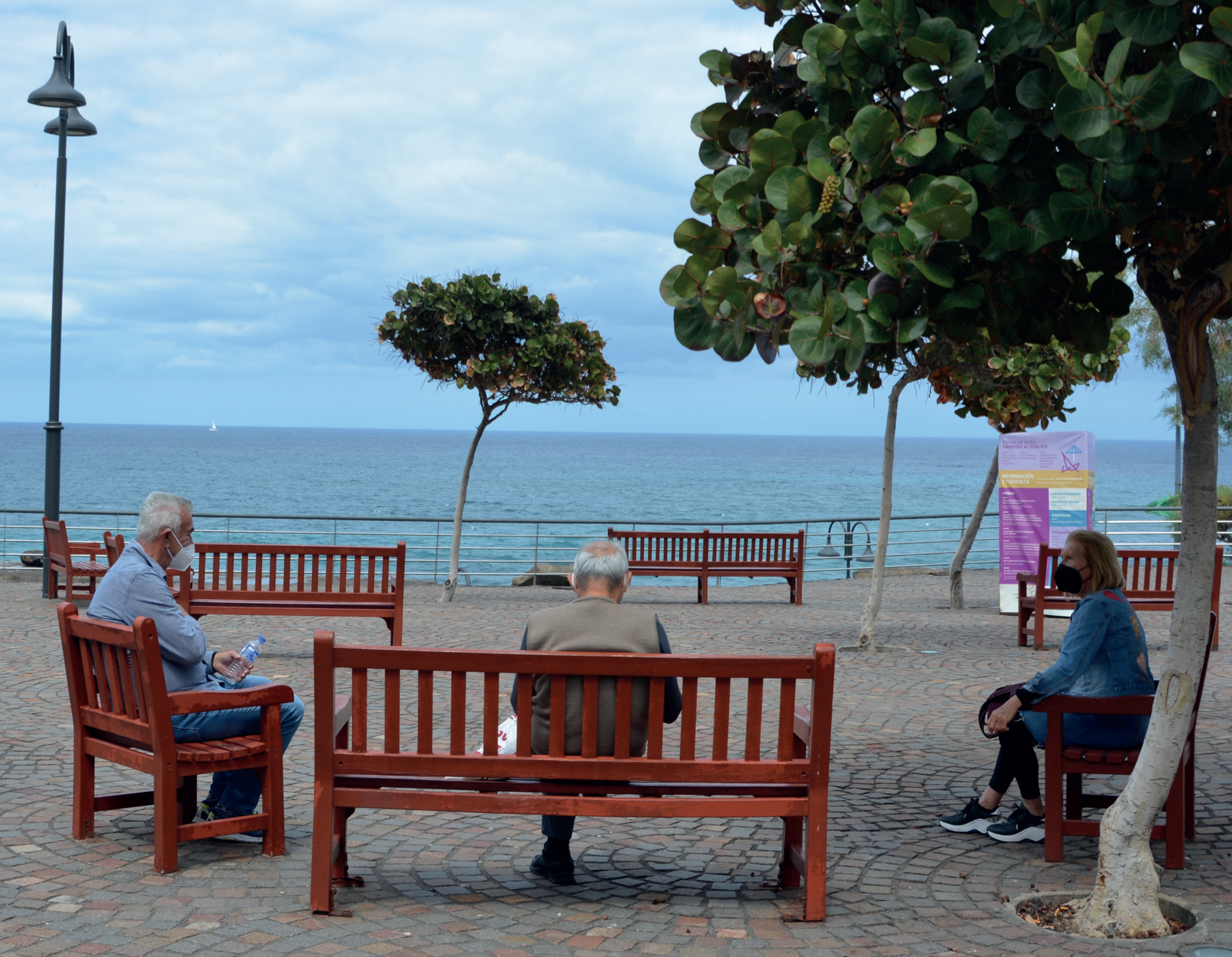




\section{Introducción}

La Monografía Comunitaria "La COVID-19 en San Cristóbal de La Laguna: una mirada desde la comunidad" se inserta en el marco de actuación del Proyecto Comunidad. Promovida por el Ayuntamiento de San Cristóbal de La Laguna en colaboración con la Universidad de La Laguna, para abordar, con perspectiva comunitaria, los actuales y futuros retos que comparten las personas que residen y/o trabajan en el municipio.

Comunidad se ha centrado, particularmente, en la aportación de elementos de valor que puedan contribuir a organizar una respuesta comunitaria e integrada ante la situación de adversidad socioeconómica generada por la COVID-19, apostando por la consolidación de un planteamiento colectivo para hacer frente a la crisis, colaborativo e impulsado desde los seis distritos municipales.

El Proyecto y las diferentes acciones realizadas aspiran a favorecer el surgimiento de procesos comunitarios, que se puedan consolidar y hacer sostenibles con el paso del tiempo, mediante la activación de estrategias participativas abiertas e incluyentes, que promuevan la confluencia y la acción conjunta de los protagonistas de cada realidad socioterritorial. Para ello se ha venido realizando una importante labor de capacitación y encuentro social con enfoque comunitario.

Con esa misma perspectiva, el planteamiento de partida ha sido generar un amplio conocimiento compartido, centrado en el periodo de pandemia, que permita identificar necesidades, aspiraciones y propuestas donde participe la comunidad aportando sus distintas miradas. Y de esta manera, afrontar, desde la fuerza que aporta la colectividad, los distintos retos sociales ahora amplificados en su complejidad tras la propagación mundial del virus SARS-CoV-2. 
Sabiendo esto, la persona puede estar informada sobre lo que está sucediendo o ha sucedido, pudiendo diferenciar lo que es prioritario para la comunidad de lo que no lo es. Esta lectura le permitirá tener una mirada más clara sobre lo que se considera el interés general, que lejos de tener en cuenta su pertinencia o bondad, solo pretende mostrarnos de manera organizada aquello que está más presente en la mayor parte de las personas y verbalizan en sus discursos.

Por tanto, la Monografía Comunitaria se tiene que leer con una doble mirada. Tan importante es lo que aparece como lo que no aparece, por las razones antes mencionadas. Quizá, la principal aportación de este documento sea esa: centrar el foco de atención en aquello que es más prioritario para las personas que forman la comunidad. Es un ejercicio para identificar y ordenar las percepciones y poder conocerlas y comprenderlas mejor.

Las potenciales aplicaciones son muchas. Y según sea el tipo de protagonista que utilice los resultados de esta Monografía Comunitaria, las posibles contribuciones tienen desarrollos y alcances diferentes. Con todo, la lectura del documento permitirá obtener unos resultados comunes y concretos para cualquier persona y/o entidad que haga uso del mismo. Aún cuando proceda de un área o departamento de la administración pública, de una entidad del tercer sector, del tejido asociativo juvenil, de las asociaciones vecinales, sea profesorado de un centro educativo, personal de un centro de salud o una persona ciudadana a título particular.

Una de las principales contribuciones es que cualquier persona o entidad puede obtener un conocimiento ordenado, preciso y se estima que certero, sobre el impacto, las expectativas, los aprendizajes y los conflictos que la propagación de la COVID-19 ha tenido sobre las personas que viven, estudian y/o trabajan en San Cristóbal de La Laguna, permitiendo así, organizar, ajustar u orientar lo que quiere hacer, si aspira a realizar alguna acción social, a lo que se considera prioritario por y para la comunidad. 


\section{Metodología}

El origen de la Monografía Comuniataria "La COVID-19 en San Cristóbal de La Laguna: una mirada desde la comunidad", realizada en el marco del Proyecto Comunidad, está en la necesidad de conocer, comprender y compartir cómo se percibe, qué respuestas se están dando y cuáles se podrían ofrecer a las complejas implicaciones y retos que ha supuesto la irrupción de la COVID-19 en el municipio lagunero.

Como es natural, al hablar de conocimientos, nos referimos a algo que nunca es definitivo. La realidad cambia, y por tanto, siempre habrá que poner en marcha mecanismos de actualización de los conocimientos disponibles. En el caso de las comunidades locales, además, existen muchos conocimientos dispersos y fragmentados, siendo difícil encontrar lo que se llama un conocimiento comunitario global. Por ello, se hace necesario producir un conocimiento básico inicial, que permita tener una visión compartida de la comunidad en la que se quiere intervenir.

En este proceso de conocimiento compartido son igual de importantes los datos y las informaciones objetivas (sociodemográficas, económicas, jurídicas, etc.), como las aportaciones subjetivas de las protagonistas (percepciones, conocimiento vital y experiencias). De la combinación de las dos dimensiones, objetiva y subjetiva, nace la comprensión y el conocimiento de la realidad y de sus posibles modificaciones. El conjunto de estas informaciones y conocimientos, que permiten tener una visión compartida de la comunidad, es lo que se denomina Monografía Comunitaria. 
La parte objetiva se ha centrado en obtener información específica sobre San Cristóbal de La Laguna que, por un lado, permita contextualizar la comunidad desde el punto de vista demográfico en las escalas municipal y distrital. Y, por otro lado, recabar y ordenar la información relativa al año de pandemia vivido desde la perspectiva epidemiológica, así como las medidas sanitarias de prevención de contagios que se han puesto en marcha por parte de las administraciones públicas.

La parte subjetiva se ha elaborado a partir de un amplio y detallado Proceso de Audición. La Audición es una metodología que se fundamenta en la escucha y en los conocimientos de los protagonistas de la comunidad. Cuando se menciona a los protagonistas de la comunidad, se hace referencia a quiénes gobiernan, trabajan, estudian o viven en un territorio determinado, en este caso, en el municipio de San Cristóbal de La Laguna.

La elección del método de la Audición para la realización de esta Monografía no ha sido casual. Además de contar con experiencias previas en el municipio en este procedimiento de investigación participativa, como la del Proyecto Intervención Comunitaria Intercultural de Taco (http://bit.ly/tacovivo), se eligió la Audición porque pone el acento en dos premisas sustanciales para cualquier acción social con perspectiva comunitaria y base participativa: la primera, se basa en escuchar más que en preguntar; la segunda, es un medio para modificar una situación con las mismas personas que han participado en la investigación.

La planificación del Proceso de Audición se realizó de acuerdo con el esquema metodológico que propone la técnica. Sin embargo, los pasos se fueron adaptando en función de los ritmos del Proyecto Comunidad, de las personas a involucrar y de las necesidades surgidas por la cambiante y compleja realidad. La Audición se ha puesto en marcha en un periodo en el que seguían afectando de manera importante las restricciones ocasionadas por la pandemia, lo que complejizó su organización y desarrollo?.

' El desarrollo del Proceso de Audición ha coincidido en toda su duración con el segundo estado de alarma en la escala nacional (Real Decreto 926/2020, de 25 de octubre, por el que se declara el estado de alarma para contener la propagación de infecciones causadas por el SARS-CoV-2) y con situaciones de nivel de alerta 3 del Gobierno de Canarias. Durante la mayor parte del tiempo, nunca bajando del nivel de alerta 2, según se recoge en la Resolución de 19 de junio de 2020 , por la que se dispone la publicación del Acuerdo por el que se establecen medidas de prevención para hacer frente a la crisis sanitaria ocasionada por el COVID-19. 
Todo ello supuso repensar de manera continua los elementos constitutivos de la investigación, analizar las dificultades y buscar respuestas, flexibles e innovadoras, que permitieran la continuidad del Proceso de Audición y la consecución de las finalidades del Proyecto Comunidad. Así, por ejemplo, los coloquios organizados e inicialmente desarrollados de manera presencial, tuvieron que adaptarse a coloquios virtuales o con otros formatos.

Primera fase. Escuchar a los protagonistas de la comunidad mediante coloquios. La primera fase se desarrolló entre los meses de noviembre de 2020 y marzo de 2021, realizando un total de 217 coloquios, en la que se escucharon a 376 personas. Los coloquios duraban una hora y se pudieron hacer mediante reuniones presenciales, por videoconferencia o de manera telefónica. Participaron 57 personas en el equipo de personas coloquiadoras que se encargaron de escuchar a las comunidad, recoger el relato y validarlo antes de finalizar la actividad de escucha.

Segunda fase. Analizar las aportaciones recogidas en las escuchas. La segunda fase comenzó a desarrollarse en marzo y finalizó en la segunda semana de abril de 2021. Durante este periodo se analizaron todos los coloquios realizados, a través de programas de análisis cualitativo que permiten codificar y organizar la información. En esta fase participó un equipo de análisis conformado por 18 personas, entre integrantes del equipo técnico del Proyecto Comunidad y personas del equipo de coloquiadores y coloquiadoras que decidieron continuar vinculadas con la segunda fase.

Tercera fase. Elaboración de la parte subjetiva de la monografía comunitaria. La tercera parte se ha desarrollado desde la tercera semana de abril hasta la primera de mayo de 2021. Con los resultados del análisis, se ha organizado la información y redactado la parte subjetiva de la monografía. En esta fase se ha contado con un equipo de redacción compuesto por 22 personas, además de las vinculadas con la segunda fase, añadiendo también a personas expertas en distintos ámbitos desde la Universidad de La Laguna.

Realizadas la parte objetiva y subjetiva, se han incorporado como anexos otros contenidos de interés que ha elaborado el Proyecto Comunidad. Estos pueden ser de utilidad para la aspiración original de la Monografía Comunitaria de contar con las herramientas necesarias para hacer frente al reto que la COVID-19 supone para la comunidad lagunera. 
1.

ming $x+1$

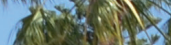

(x)

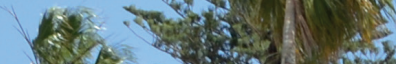

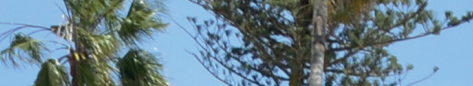

Nin 25

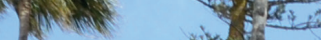

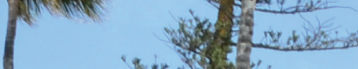

wen

$4 \mathrm{~s} \times \mathrm{x}$

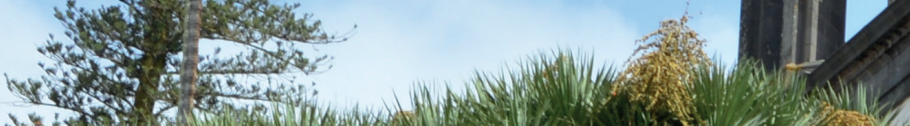

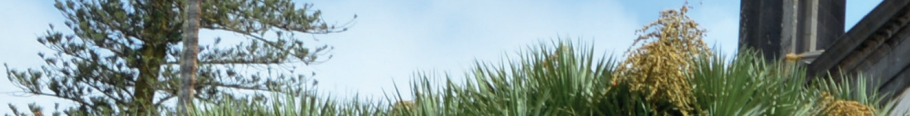

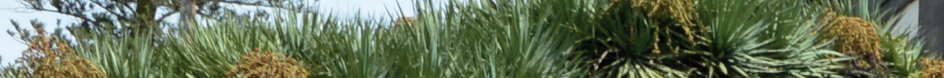

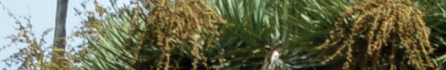

7. 1 .

the

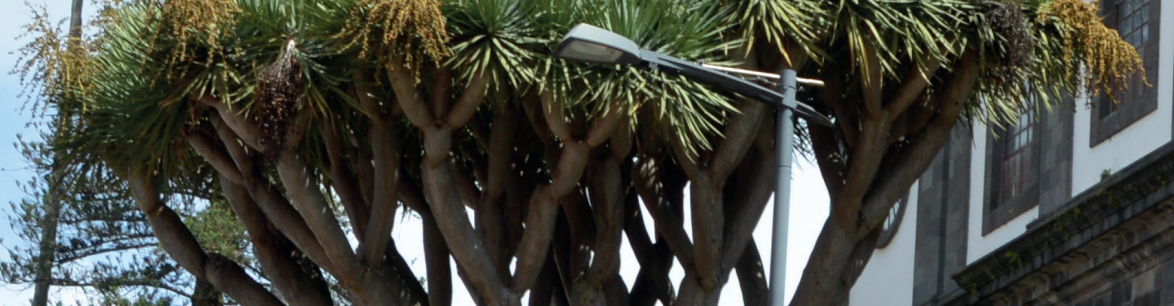
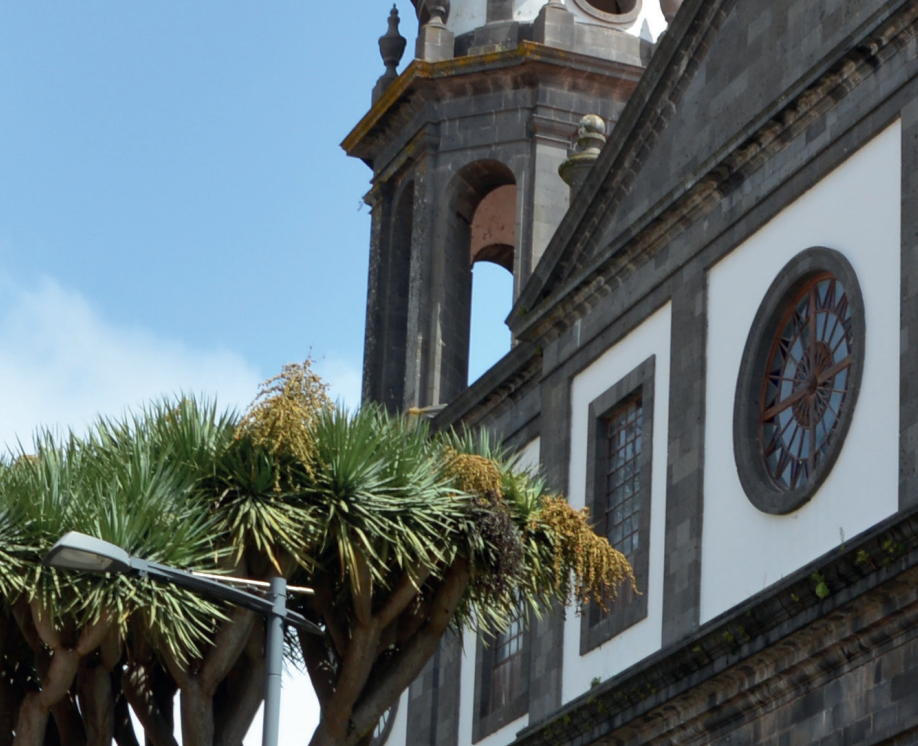

\section{0}
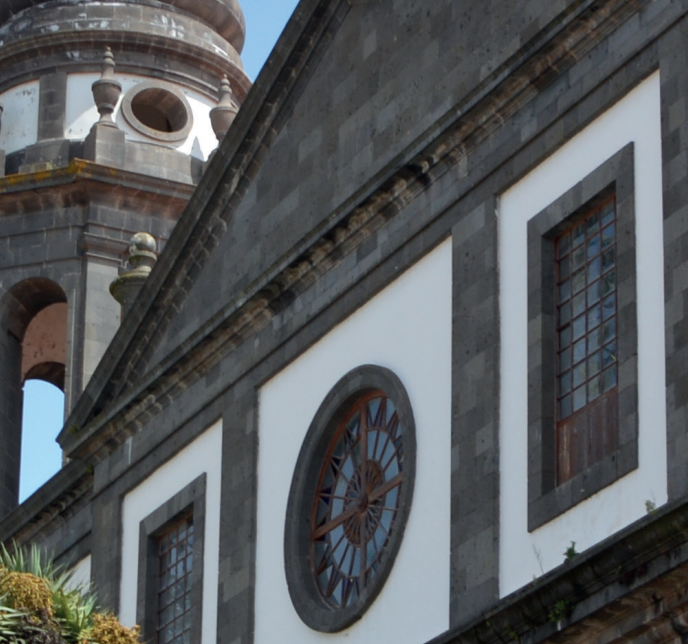
D14

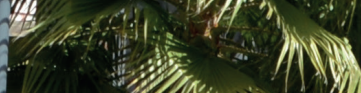
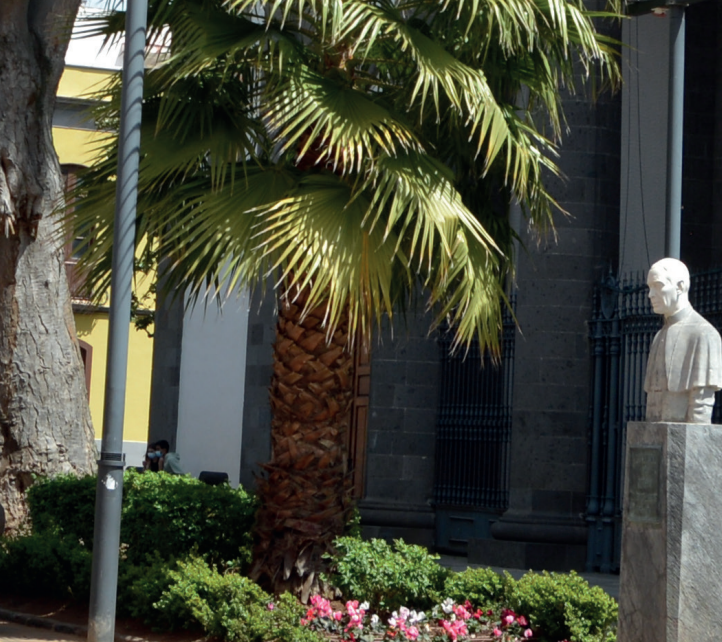



\section{Un año de la COVID-19: La información objetiva}




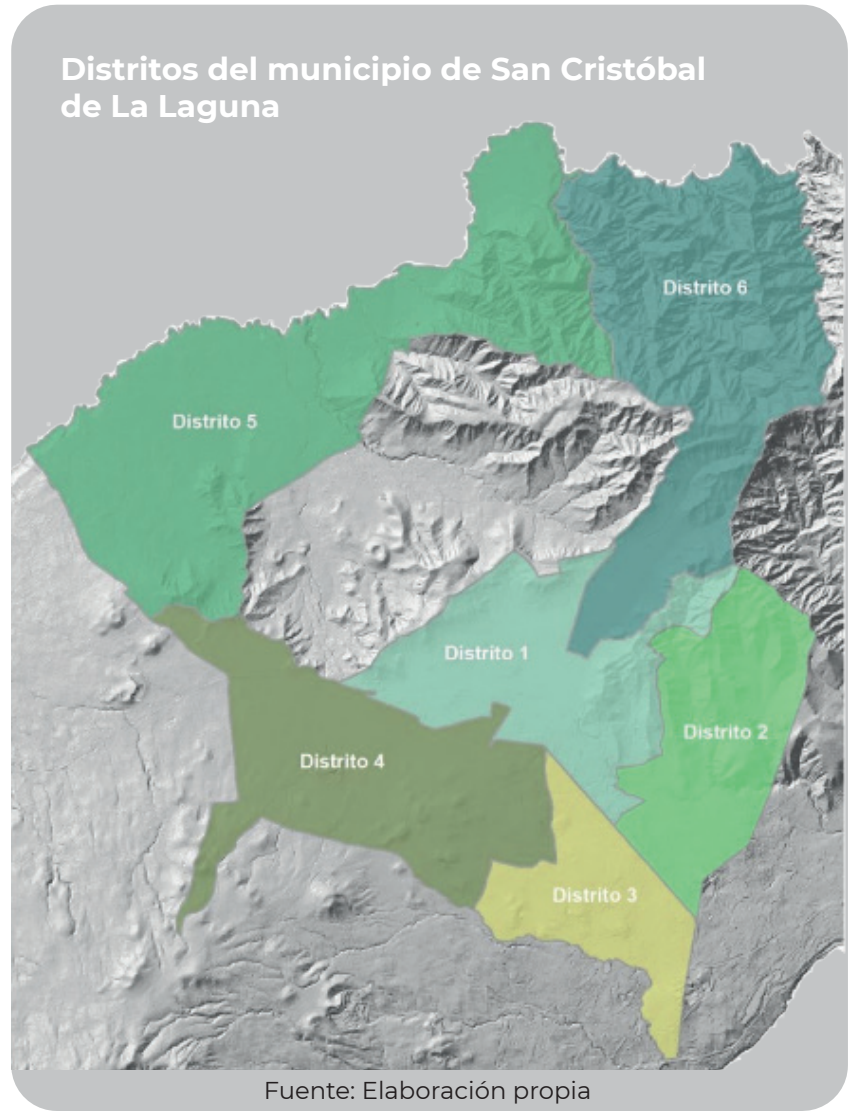

\section{El contexto geodemográfico del municipio de San Cristóbal de La Laguna \\ Carlos Flores Rodríguez, geógrafo}

San Cristóbal de La Laguna es un municipio canario que está localizado en el noreste de la isla de Tenerife, siendo el octavo con mayor superficie $(102,06 \mathrm{~km} 2)$ y el segundo más poblado a escala insular. Se enmarca en el área metropolitana, conformada también por los términos municipales de El Rosario, Tegueste y Santa Cruz de Tenerife, siendo una pieza clave en la movilidad entre las vertientes norte y sur. Internamente, se organiza en seis distritos divididos en 24 entidades de población y 107 secciones censales².
A continuación se realizará un estudio básico de las principales variables geodemográficas que describen la realidad poblacional de San Cristóbal de La Laguna, centrado en el periodo que comprende desde 2010 a 2020, según los datos extraídos del Instituto Canario de Estadística y del Instituto Nacional de Estadística (en adelante, ISTAC e INE) a escala municipal y distrital. En primer lugar, se analizará el crecimiento demográfico; en segundo lugar, la estructura por edad y sexo en las dos escalas de análisis, así como la aplicación de indicadores demográficos, incluyendo también las escalas insular, regional y estatal; y por último, un análisis de la población según el lugar de nacimiento y su origen.

\section{Crecimiento de la población municipal y distrital entre 2010 y 2020}

En este decenio se advierten tres etapas bien marcadas, en las que la evolución de la población ha experimentado fases de crecimiento y disminución. Así, entre 2010 y 2012 (primera etapa), la población a escala municipal experimenta una tendencia ligeramente ascendente, alcanzando la cifra de 153.224 habitantes en 2012. A partir de 2013 (segunda etapa), se registra una tendencia descendente, avanzando hasta 2016 con leves movimientos de crecimiento y decrecimiento. Es en 2017 (tercera etapa) cuando el número de habitantes del municipio vuelve a crecer. En esta ocasión a un ritmo mayor, reflejando un empadronamiento de 158.911 habitantes en 2020 (Gráfico 1).

La explicación del estancamiento del crecimiento poblacional entre 2010 y 2012 se relaciona con los efectos de la crisis socioeconómica que se inició a finales de la primera década del siglo XXI. Por un lado y debido a dicha crisis, el saldo total migratorio disminuyó con respecto a los años anteriores, reflejo de la menor llegada de inmigrantes y el aumento de la emigración. Con respecto a la dinámica natural de la población, el crecimiento vegetativo siguió la

${ }^{2}$ El distrito 1, situado en el centro del municipio, está compuesto por las entidades de población de Gracia, San Cristóbal de La Laguna (cabecera municipal), San Lázaro y La Vega Lagunera. El distrito 2, ubicado al sureste, está conformado por La Cuesta, Finca España y Los Valles. El distrito 3, ubicado al sur, contiene a Las Chumberas, Geneto, Guajara y Taco. En el distrito 4, localizado al suroeste, se organizan Los Andenes, Los Baldíos, Guamasa, El Ortigal y Los Rodeos. El distrito 5 , ubicado al norte o sector costero, está integrado por las entidades de población de Bajamar, Punta del Hidalgo, Tejina y Valle de Guerra. Por último, el distrito 6 está conformado por Jardina, Las Mercedes, Las Montañas y Vega de Las Mercedes, en las estribaciones de Anaga y en la Reserva de la Biosfera que comprende ese macizo. 


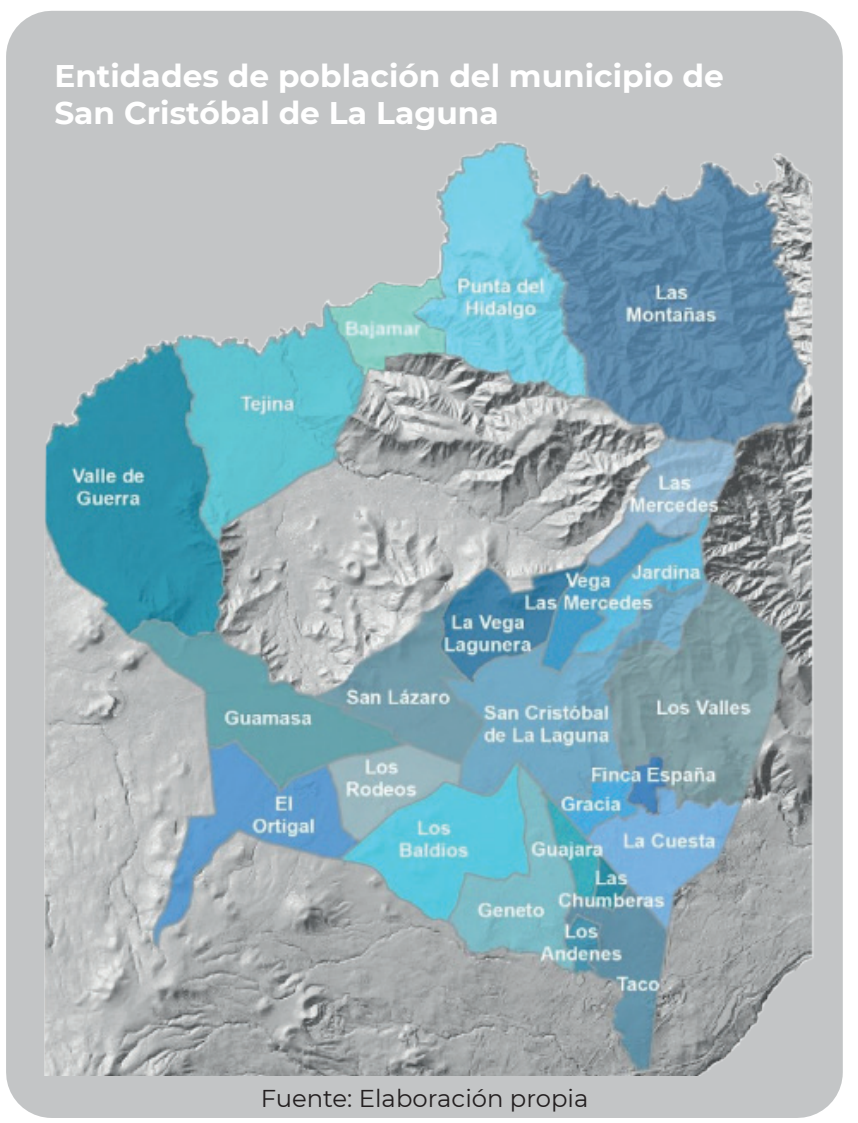

tendencia a la baja registrada en años anteriores, aumentando o manteniéndose estable la cifra de defunciones y estancándose el número de nacimientos. En la segunda etapa, donde disminuye el número de habitantes, se observa cómo el saldo migratorio disminuye y entra también en valores negativos el crecimiento vegetativo.

A partir de 2017, las cifras de inmigración vuelven a aumentar a la vez que las de emigración se mantienen, mientras que el crecimiento vegetativo se sitúa en valores negativos debido al aumento de defunciones y a la disminución de los nacimientos (ISTAC).

\section{Evolución de la población según sexo en el municipio de San Cristóbal de La Laguna}

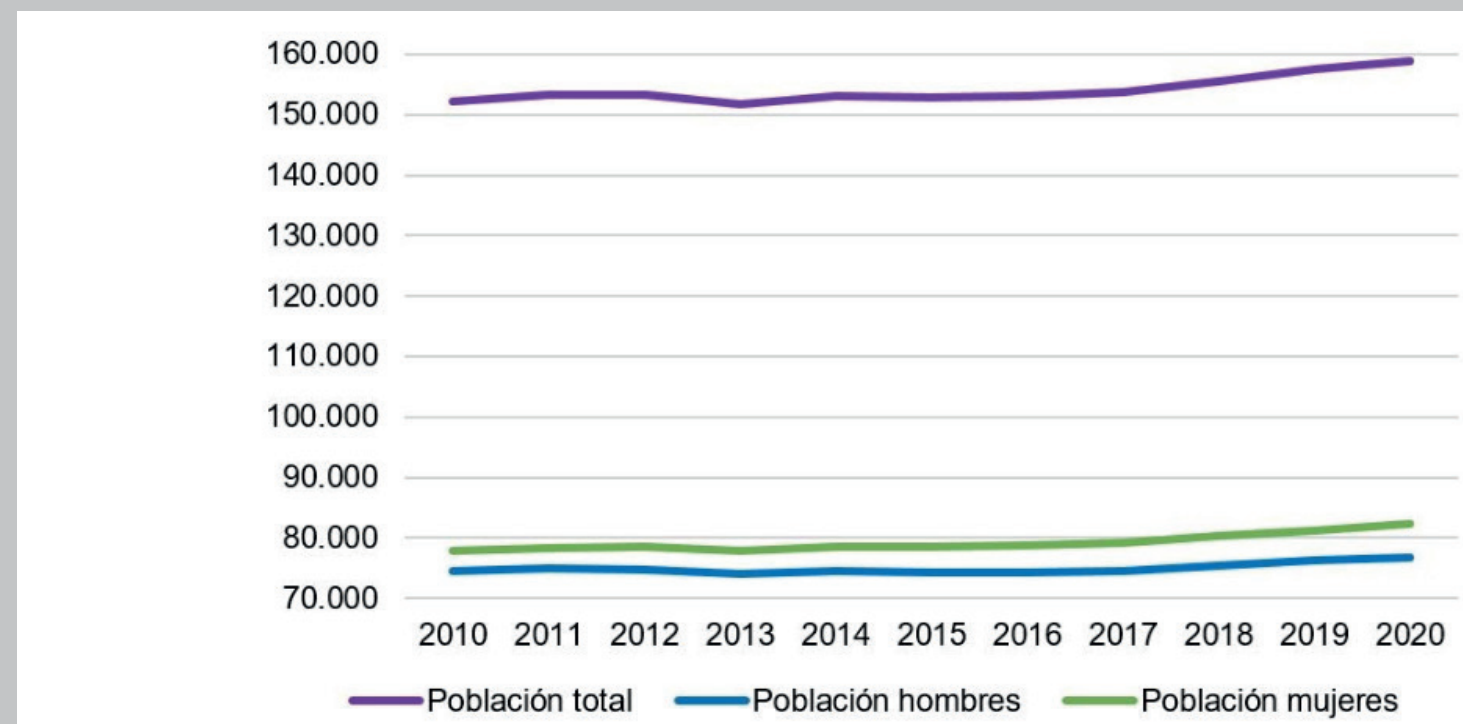

Fuente: Padrón Municipal de Habitantes 2010-2020, Instituto Canario de Estadística (ISTAC). Elaboración propia 


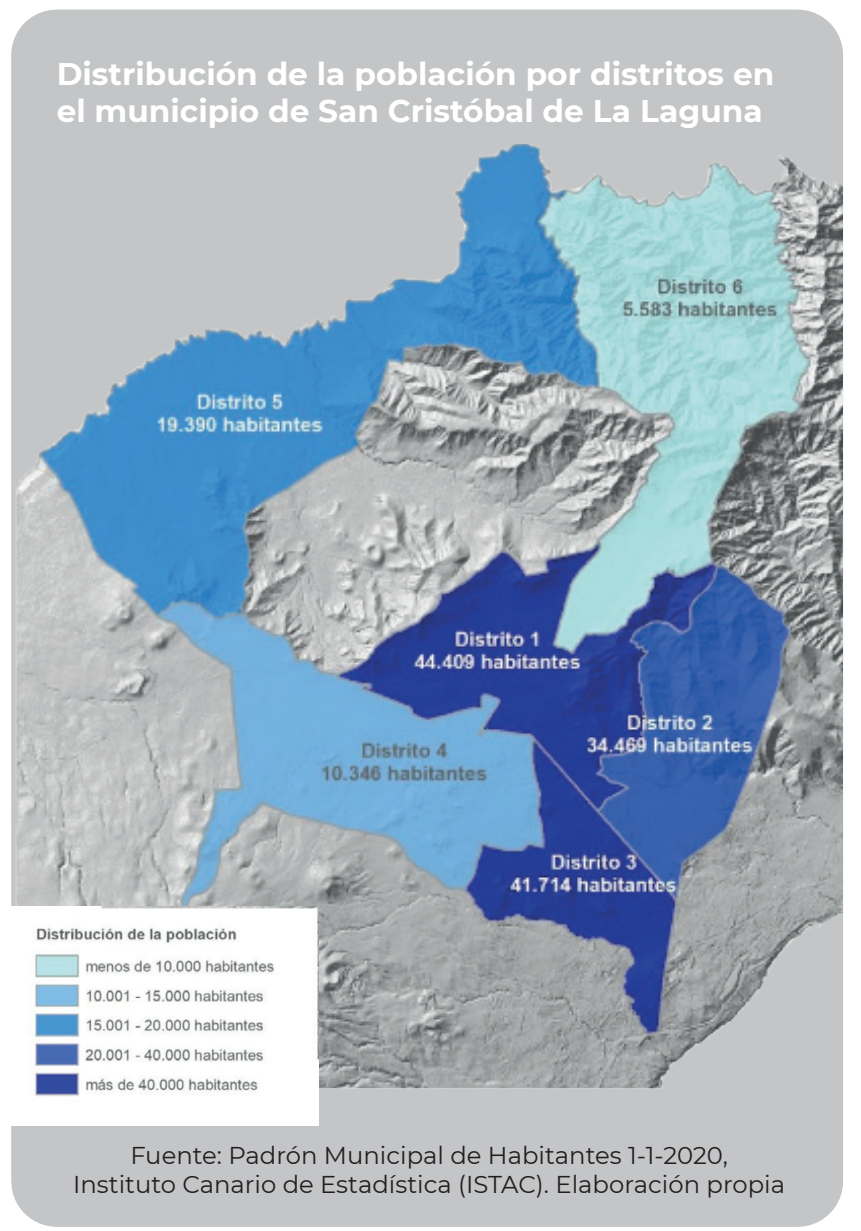

En relación con la población según sexos, se puede observar que durante todos los años analizados existe un predominio de la población femenina, acentuándose esta tendencia a partir de 2017. Como se hará mención más adelante, este fenómeno se debe a la feminización de la población a causa de un progresivo envejecimiento y a los efectos de la inmigración. Esta tendencia progresiva se confirma durante el periodo estudiado, ya que, en 2010 había un 48,9\% de hombres y un $51,1 \%$ de mujeres, mientras que en 2020 las mujeres suponían el 51,7\% de la población.

El distrito 1, que engloba la cabecera municipal lagunera, es el que más población registra de los seis distritos en los que se organiza San Cristóbal de La Laguna, ofreciendo una población en 2020 de 44.409 habitantes, experimentando un crecimiento y una disminución alternante en el número de habitantes en los últimos diez años. Por su parte, los distritos 2 y 3 presentan una evolución muy similar entre 2010 y 2020, obteniendo ambos una población de 37.469 y 41.714 habitantes respectivamente, tratándose de los distritos que han visto cómo su población ha crecido de manera permanente. Los distritos 4 y 6 han experimentado, al igual que el distrito 1, leves tendencias ascendentes y descendentes durante el decenio, terminando con menos población que en 2010. Por último, el distrito 5 suma 19.390 personas inscritas en el padrón municipal en 2020.

Evolución de la población según distrito en el municipio de San Cristóbal de La Laguna

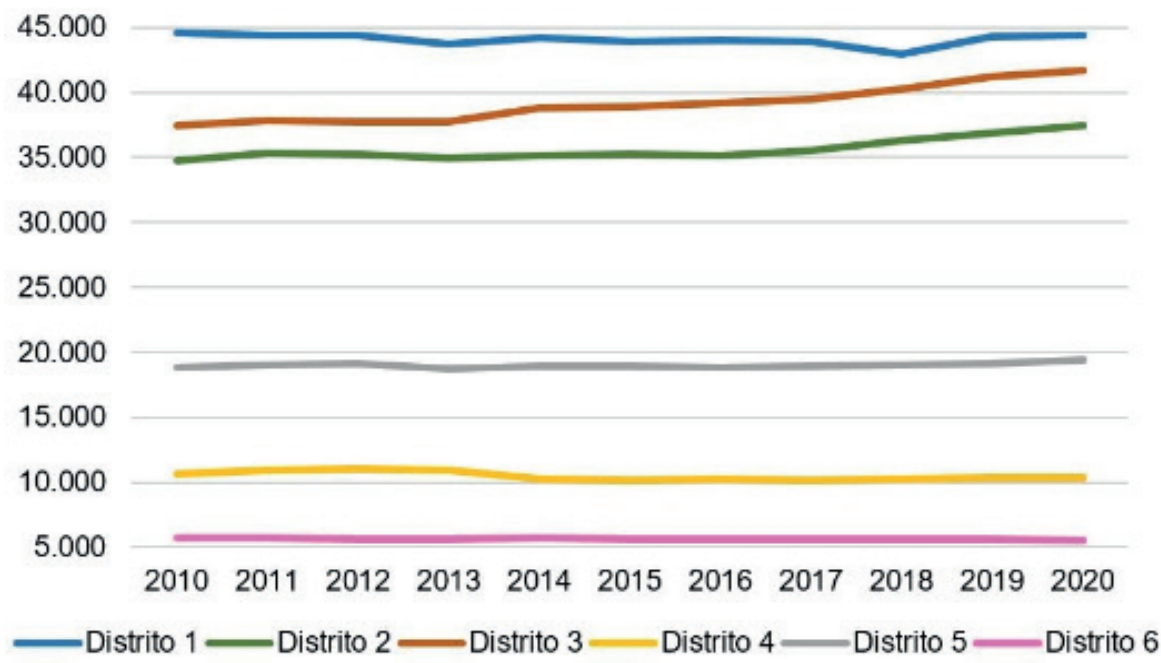




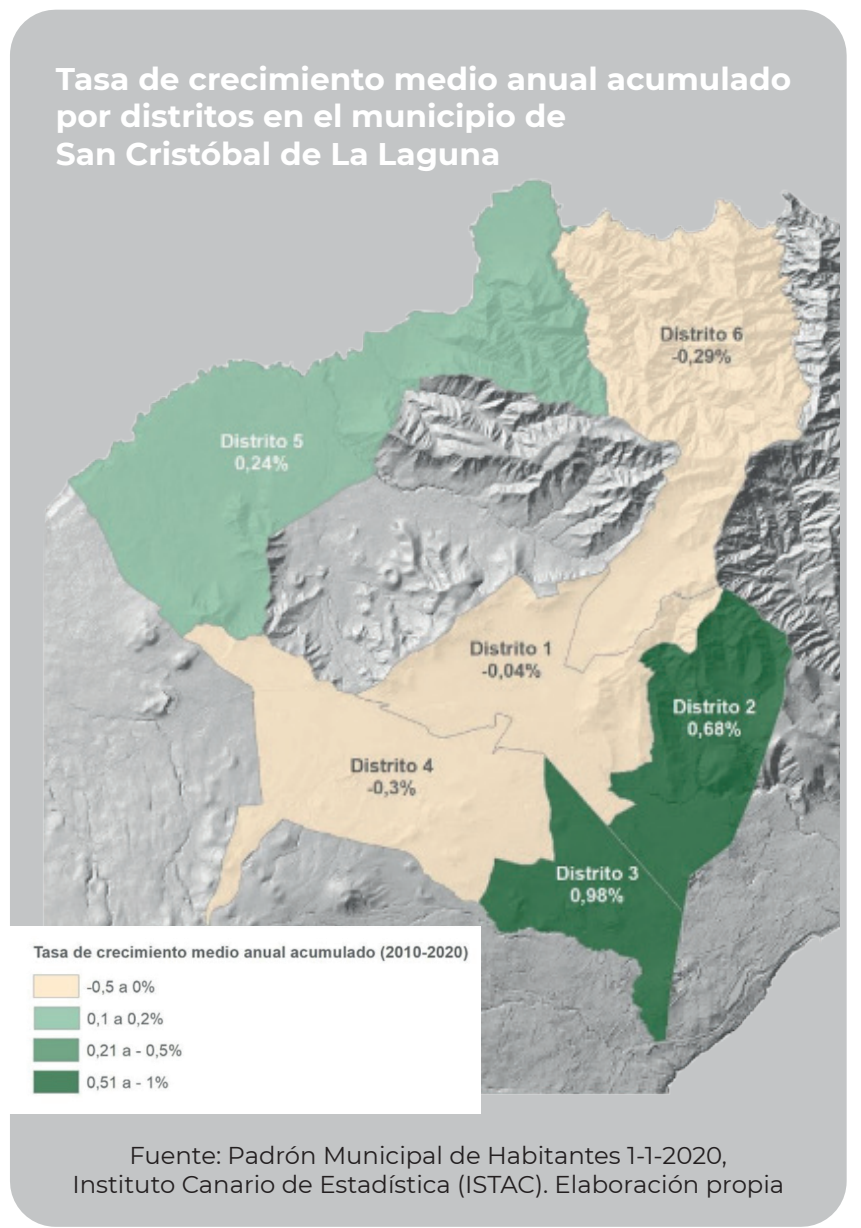

Por tanto, los seis distritos tienen dinámicas de crecimiento distintas (Tabla 1), si bien comparten rasgos generales con la evolución de la población a escala municipal. Mientras los distritos 1, 4 y 6 experimentan una pérdida poblacional entre 2010 y 2020, los distritos 2, 3 y 5 cuentan en 2020 con más personas censadas que en 2010 (Mapa 1 y 2). Hay que mencionar que el estancamiento, tanto en la primera etapa como en la segunda, en prácticamente todos los distritos, se debe a los efectos de la crisis de 2008, atenuándose estas repercusiones en la población a partir de la tercera etapa antes mencionada, donde la población crece de nuevo, variando en intensidad según el distrito.

Se establecen diferencias entre sexos en todos los distritos, salvo en el 4, en el que la evolución es igual que a escala municipal, partiéndose de valores donde el número de mujeres es mayor que el de hombres en 2010 y acentuándose esta tendencia hasta 2020. Destaca particularmente el distrito 2, donde la población femenina pasa de tener en 2010 un 51,4\% de población a un $52,9 \%$ en 2020.

Distribución de la población por distritos en el municipio de San Cristóbal de La Laguna

\begin{tabular}{|l|c|c|c|c|c|c|}
\hline Año & Distrito 1 & Distrito 2 & Distrito 3 & Distrito 4 & Distrito 5 & Distrito 6 \\
\hline $\mathbf{2 0 1 0}$ & 44.621 & 34.788 & 37.475 & 10.693 & 18.879 & 5.766 \\
\hline $\mathbf{2 0 1 1}$ & 44.427 & 35.307 & 37.805 & 10.904 & 19.062 & 5.682 \\
\hline $\mathbf{2 0 1 2}$ & 44.425 & 35.277 & 37.742 & 10.980 & 19.167 & 5.633 \\
\hline $\mathbf{2 0 1 3}$ & 43.738 & 34.948 & 37.728 & 10.896 & 18.758 & 5.650 \\
\hline $\mathbf{2 0 1 4}$ & 44.167 & 35.176 & 38.761 & 10.265 & 18.939 & 5.701 \\
\hline $\mathbf{2 0 1 5}$ & 43.903 & 35.220 & 38.918 & 10.196 & 18.957 & 5.649 \\
\hline $\mathbf{2 0 1 6}$ & 43.988 & 35.178 & 39.168 & 10.236 & 18.884 & 5.657 \\
\hline $\mathbf{2 0 1 7}$ & 43.913 & 35.523 & 39.509 & 10.184 & 18.912 & 5.614 \\
\hline $\mathbf{2 0 1 8}$ & 42.950 & 36.341 & 40.274 & 10.214 & 19.056 & 5.596 \\
\hline $\mathbf{2 0 1 9}$ & 44.303 & 36.918 & 41.195 & 10.336 & 19.169 & 5.582 \\
\hline $\mathbf{2 0 2 0}$ & 44.409 & 37.469 & 41.714 & 10.346 & 19.390 & 5.583 \\
\hline
\end{tabular}

Fuente: Padrón Municipal de Habitantes 2010-2020, Instituto Canario de Estadística (ISTAC). Elaboración propia 


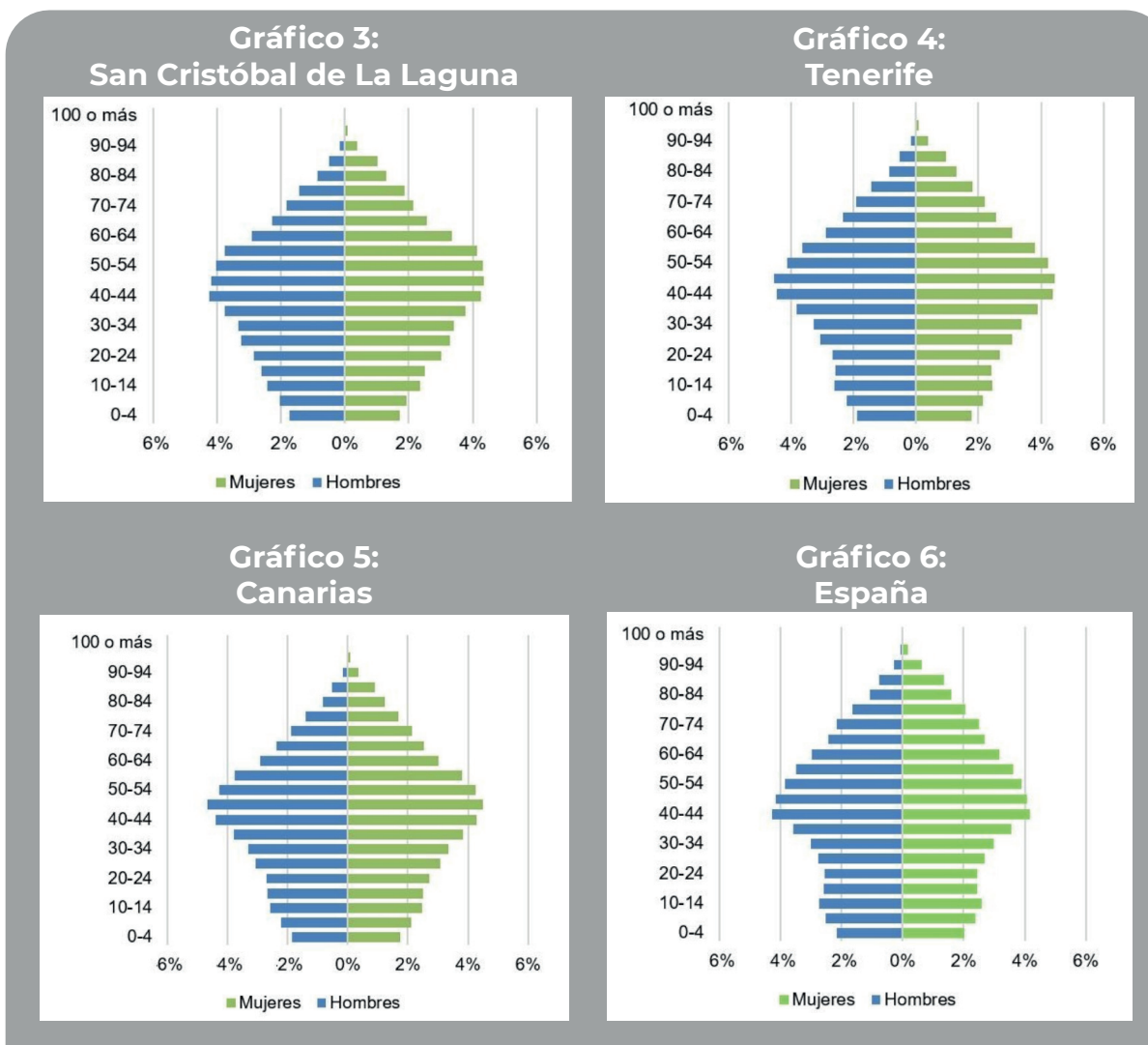

\section{Gráfico 7: Distrito 1}

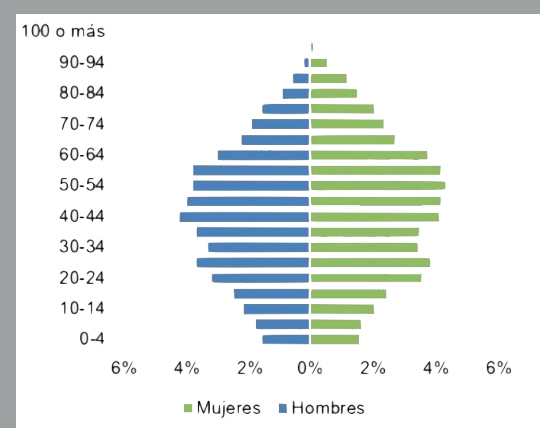

Gráfico 10: Distrito 4

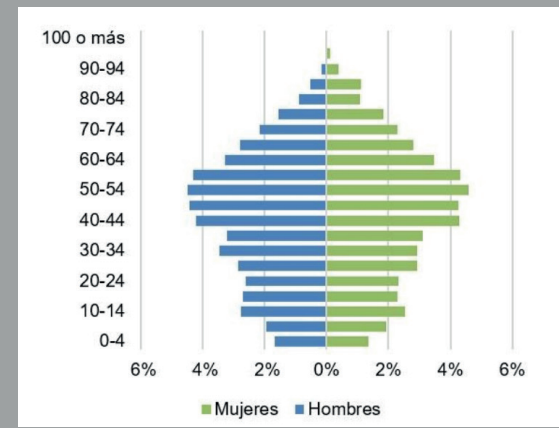

Gráfico 8: Distrito 2

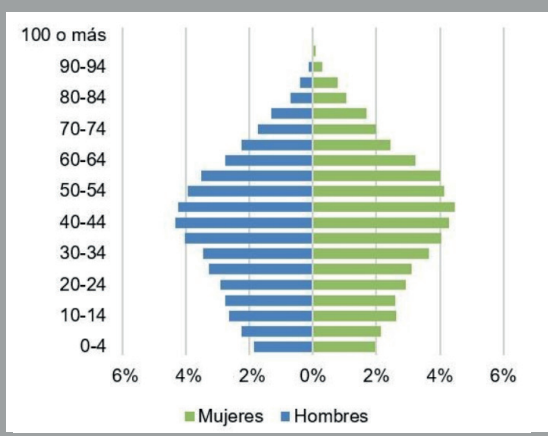

Gráfico 11: Distrito 5

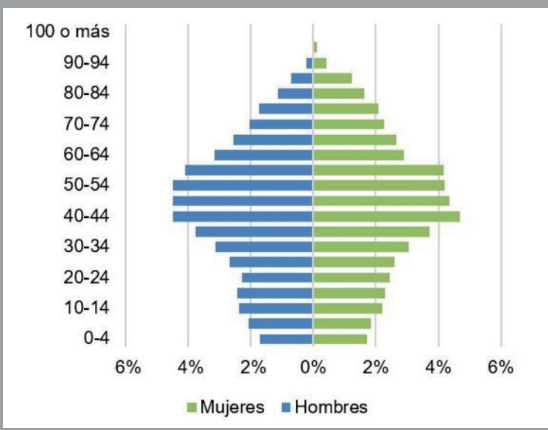

Gráfico 9: Distrito 3

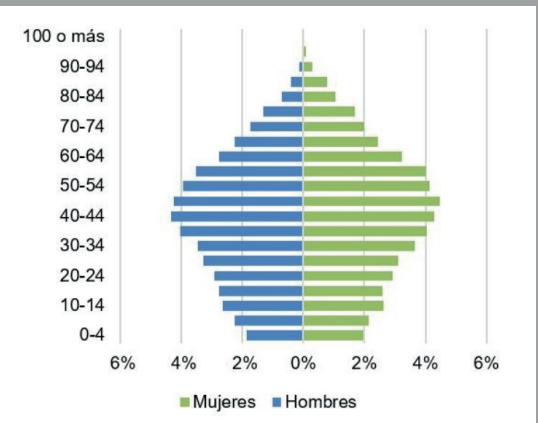

Gráfico 12: Distrito 6

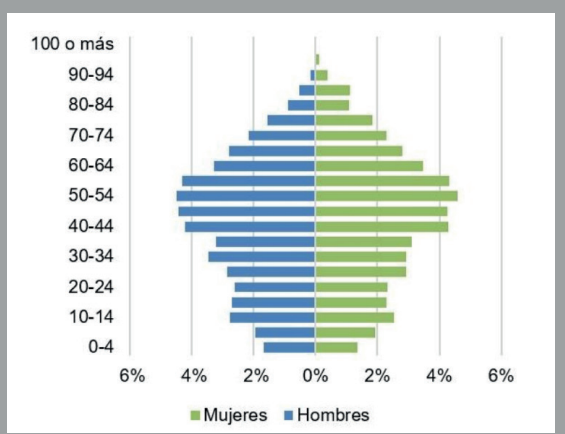

Fuente: Padrón Municipal de Habitantes 1-1-2020, Instituto Canario de Estadística (ISTAC). Elaboración propia 


\section{Estructura de la población de San Cristóbal de La Laguna y sus distritos}

Analizar la estructura de la población, teniendo en cuenta las variables de sexo y edad, aporta conclusiones relevantes acerca del perfil demográfico de San Cristóbal de La Laguna y sus distritos. A continuación, se detalla la estructura de la población a escala municipal y distrital, en comparación con las de la isla de Tenerife, Canarias y España en 2020.

En una primera aproximación, se puede observar cómo en 2020 la estructura demográfica del municipio tiene una dinámica regresiva (Gráfico 3), es decir, muestra síntomas claros de llegar al final de la transición demográfica, donde la edad media de la población en el municipio es elevada, alcanzando los 43 años. Si se analiza de manera comparada con el conjunto insular de Tenerife (42,8 años) o el conjunto regional (42,6 años), se refleja que hay un ligero envejecimiento de la población en el municipio, aunque se sitúa por debajo de la edad media a nivel estatal (43,6 años).

Si se atiende a los distritos, se pueden observar estructuras de población que dan cuenta de dinámicas regresivas. Las edades medias, aunque elevadas, se muestran diferentes. El distrito 2 (42,1 años) y el distrito 3 (41,7 años) cuentan con edades medias inferiores al conjunto municipal. Por otro lado, el distrito 5 (44,6 años) y el distrito 6 (44,2 años) son los que se muestran más envejecidos.

La estructura poblacional de San Cristóbal de La Laguna, así como la de sus distritos, a pesar de las pequeñas diferencias en la edad media, se encuentran en correlación con las dinámicas poblacionales del conjunto insular, regional y estatal. Es decir, actualmente las estructuras poblacionales municipales siguen un patrón que revela un envejecimiento notable de la estructura demográfica, siendo esta afirmación corroborada por la edad media y la forma de regresión de las estructuras de población. Sin embargo, hay más parámetros que confirman esta tendencia, como la feminización de la población, los índices de envejecimiento y juventud, la tasa de dependencia y la tasa de población activa.

En relación con los índices de envejecimiento y de juventud (tabla 2), como se ha apuntado anteriormente, la edad media es elevada y esto indica que hay un porcentaje elevado de población de 65 y más años (16,5\%), mientras que el porcentaje de población joven de menos de 15 no lo es tanto (12,2\%). Estos datos muestran una tendencia similar en todos los distritos, siendo más notable en aquellos que cuentan con medias de edad más elevadas (distrito 5 y 6) frente a los que ofrecen resultados más bajos (distrito 2 y 3 ).

La feminización de la población incide en su envejecimiento porque las mujeres cuentan con una mayor esperanza de vida que los hombres, y por tanto, a mayor presencia de mujeres en la estructura poblacional, más personas longevas contabiliza el municipio. En este sentido, atendiendo a la relación entre sexos, en el municipio hay 93 hombres por cada 100 mujeres. Tendencia que se ha ido consolidando con el paso de los años como se ha mencionado anteriormente.

Con respecto a la tasa de dependencia, que determina la relación entre personas en edad laboral (16-64 años) y el resto (0-14 años y 65 y más años), cabe destacar que en San Cristóbal de La Laguna es del 40,3\%, estando sensiblemente por debajo de la media nacional (51,1\%), pero superior a la media regional. En buena medida porque, a pesar de contar con una estructura más envejecida y feminizada, cuenta con una población activa del 71,3\%, un porcentaje mayor que la media insular y regional, debido a la presencia de población migrante y estudiantado universitario que inciden sobremanera en el grupo de edad entre los 16 y los 64 años. 
Población según lugar de nacimiento y principales procedencias en San Cristóbal de La Laguna y sus distritos

En cuanto a la procedencia de las personas habitantes de San Cristóbal de La Laguna, considerando el año 2020, el 43,3\% de las mismas proviene de otro municipio de la provincia de Santa Cruz de Tenerife, mientras que solo el $33,1 \%$ es nacida en el propio municipio. El 14,6\% de la población ha nacido en el extranjero y el $9 \%$ en otras provincias de España

A escala distrital las cifras son dispares. Mientras que en los distritos 1, 2 y 3, los más poblados, la mayoría de la población tienen como lugar de nacimiento otros municipios de la provincia de Santa Cruz de Tenerife, en los distritos 4, 5 y 6 , los que menos población registran, la mayor parte de la población ha nacido en el municipio. En relación con la población de origen extranjero, se concentra en el distrito $2(20,5 \%)$ y en el distrito 3 (17,6\%), mientras que en los distritos 4 y 6 están en torno al $7 \%$ del conjunto de la población.
En 2020 y a escala municipal, si se atiende a la población nacida en el extranjero, el 75,3\% de la población proviene de América, con una alta presencia de mujeres (54,9\%). En segundo lugar se encuentra la población europea con un $17,2 \%$, también feminizada $(54,2 \%)$. Las procedencias africana, asiática y oceánica no llegan al 5\% del total. Si se analiza atendiendo a los distritos, al igual que en el ámbito municipal, las procedencias americanas siguen siendo las mayoritarias, aunque, en el caso de los distritos 2 y 3 , el porcentaje es mayor que en el resto (82\%). Igual, en relación con las personas de origen europeo, son los distritos 2 y 3 los que presentan un mayor porcentaje y también ascienden sobre la media municipal hasta llegar al 20\%.

En relación con los países de origen, en San Cristóbal de La Laguna las principales procedencias son Venezuela (44,1\%), Cuba (12,9\%), Argentina (4,2\%) y Colombia (3,5\%). La población de origen europeo proviene de Italia (4,7\%), Alemania (3,7\%) y Francia (1,3\%). El colectivo mayoritario de África procede de Marruecos (2\%), y el correspondiente a Asia de China (1,4\%). La población que ha nacido en Venezuela también representa la procedencia mayoritaria en todos los distritos, donde destacan las cifras de los distritos 3 y 6 , ambos con más del $50 \%$ de población que ha nacido en el extranjero procedente de ese país con el que

Indicadores demográficos por distritos en el municipio de San Cristóbal de La Laguna

\begin{tabular}{|l|c|c|c|c|c|c|}
\cline { 2 - 7 } & Edad media & $\begin{array}{c}\text { Índice de } \\
\text { envejecimiento (\%) }\end{array}$ & $\begin{array}{c}\text { Índice de } \\
\text { juventud (\%) }\end{array}$ & Razón de sexo & $\begin{array}{c}\text { Tasa de } \\
\text { dependencia(\%) }\end{array}$ & $\begin{array}{c}\text { Población } \\
\text { Activa (\%) }\end{array}$ \\
\hline España & 43,6 & 19,4 & 14,4 & 96,1 & 51,1 & 66,2 \\
\hline Canarias & 42,6 & 16,1 & 13,0 & 97,9 & 41,1 & 70,9 \\
\hline Tenerife & 42,8 & 16,5 & 13,1 & 96,3 & 42,0 & 70,4 \\
\hline San Cristóbal & & 16,5 & 12,2 & 93,3 & 40,3 & 71,3 \\
\hline La Laguna & 42,9 & 17,7 & 10,6 & 89,2 & 39,4 & 71,7 \\
\hline Distrito 1 & 43,8 & 15,2 & 12,9 & 92,7 & 39,1 & 71,9 \\
\hline Distrito 2 & 42,1 & 14,9 & 13,5 & 94,2 & 39,5 & 71,7 \\
\hline Distrito 3 & 41,7 & 17,8 & 12,2 & 100,3 & 42,9 & 70,0 \\
\hline Distrito 4 & 44,1 & 18,8 & 11,9 & 98,3 & 44,3 & 69,3 \\
\hline Distrito 5 & 44,6 & 17,6 & 12,0 & 94,9 & 42,0 & 70,0 \\
\hline Distrito 6 & 44,2 & & & & & 7 \\
\hline
\end{tabular}


existen estrechos lazos socioculturales. Por su parte, la población nacida en Alemania tiene una fuerte presencia en el distrito 5, con un $15 \%$ sobre el total de la población de origen extranjero.

En síntesis, la población en el municipio de San Cristóbal de La Laguna tiende a un envejecimiento progresivo, todavía de carácter moderado, y a una ralentización del crecimiento demográfico que, a pesar de todo, se mantiene en valores positivos gracias al saldo migratorio. Este comportamiento es dispar en el territorio, pudiendo confrontar dos modelos.

Un modelo, con el que se corresponde el distrito 6 y el distrito 4, donde el crecimiento demográfico es negativo, hay menos concentración de la población y esta se halla más envejecida, con una menor presencia de población migrante y menor dinamismo demográfico. El otro modelo se corresponde con los distritos 2 y 3 , donde la concentración de población es alta con una densidad de población elevada, en los que el crecimiento demográfico se mantiene y repunta, en buena medida, por las aportaciones de la población migrante, en especial, de origen latinoamericano.
Los distritos 1 y 5, muestran características muy similares de ambos modelos principales, sin definirse de manera clara por uno u otro. Mientras que en el distrito 1 el envejecimiento de la población es menos acusado, con una alta concentración de habitantes -el más pobladopresenta un crecimiento negativo. En cambio, el distrito 5, aún creciendo de manera positiva, el envejecimiento está más presente, cuestión a la que contribuye la concentración de población migrante, en especial, de origen europeo.

Población según lugar de nacimiento por distrito en San Cristóbal de La Laguna

\begin{tabular}{|c|c|c|c|c|c|c|c|c|c|c|c|}
\hline & Total & $\begin{array}{l}\text { Mismo } \\
\text { municipio }\end{array}$ & $\%$ & $\begin{array}{c}\text { Otro } \\
\text { municipio } \\
\text { misma } \\
\text { provincia }\end{array}$ & $\%$ & $\begin{array}{l}\text { Distinta } \\
\text { provincia }\end{array}$ & $\%$ & $\begin{array}{l}\text { Resto } \\
\text { de } \\
\text { España }\end{array}$ & $\%$ & $\begin{array}{l}\text { Otro } \\
\text { país }\end{array}$ & $\%$ \\
\hline Distrito 1 & 44.409 & 1.5618 & 35,2 & 18.048 & 40,6 & 1.662 & 3,7 & 3.836 & 8,6 & 5.245 & 11,8 \\
\hline Distrito 2 & 37.469 & 9.135 & 24,4 & 17.354 & 46,3 & 950 & 2,5 & 2.356 & 6,3 & 7.674 & 20,5 \\
\hline Distrito 3 & 41.714 & 9.830 & 23,6 & 21.214 & 50,9 & 1195 & 2,9 & 2.134 & 5,1 & 7.341 & 17,6 \\
\hline Distrito 4 & 10.346 & 4.695 & 45,4 & 4.157 & 40,2 & 251 & 2,4 & 4.54 & 4,4 & 789 & 7,6 \\
\hline Distrito 5 & 19.390 & 10.490 & 54,1 & 5.949 & 30,7 & 284 & 1,5 & 8.66 & 4,5 & 1.801 & 9,3 \\
\hline Distrito 6 & 5.583 & 2.824 & 50,6 & 2.024 & 36,3 & 107 & 1,9 & 245 & 4,4 & 383 & 6,9 \\
\hline $\begin{array}{c}\text { San Cristóbal de La } \\
\text { Laguna }\end{array}$ & 15.8911 & $52 . .592$ & 33,1 & 68.746 & 43,3 & 4.449 & 2,8 & 9.891 & 6,2 & 23.233 & 14,6 \\
\hline
\end{tabular}




\section{EI SARS-CoV-2 y la evolución epidemiológica de la COVID-19 en San Cristóbal de La Laguna}

Basilio Valladares Hernández, epidemiólogo

El 14 de marzo de 2020, el Gobierno español activó el Estado de Alarma en todo el territorio nacional como consecuencia de la pandemia declarada por la Organización Mundial de la Salud (OMS) ante la presencia y expansión del SARS-CoV-2 por todo el mundo. El conocimiento de lo que ha ocurrido a lo largo del año pasado y principios de este 2021, debe ser la base para entender, actuar y corregir futuros problemas a consecuencia de la permanencia del citado virus.

Hagamos un poco de historia. A finales de diciembre de 2019, nos llegó la noticia de que en Wuhan, una ciudad china de once millones de habitantes, que es la capital de la provincia de Hubei, se había declarado una neumonía de origen desconocido. Se pensó que la génesis de esa neumonía había sido un mercado de abastos, donde había aparecido un nuevo virus que producía una neumonía a la que dieron por nombre la "neumonía de Wuhan".

Se hicieron todas las especulaciones posibles sobre su origen. Se afirmó que procedía del murciélago y que los enfermos se contagiaron por haber comido sopa de murciélago o por ingerir mariscos contaminados en el mercado. La aparición de la neumonía en una familia que no había estado en el mercado, sino de visita en un hospital de Wuhan, hizo pensar que la vía de transmisión podía ser otra.

El mercado fue clausurado y en nuestras mentes, en las de las personas investigadoras de la OMS y en las de las representantes del Ministerio de Sanidad del Gobierno de España, radicaba que había algo nuevo, pero que se centraba en China y que no nos afectaría. Sorprendentemente, la primera semana de enero de 2020 ya estaba secuenciado el genoma de este nuevo patógeno.
Era un virus de los denominados ARN, con un genoma de unas 30.000 bases y cuya morfología era de un Coronavirus.

Se asemejaba bastante a otros Coronavirus aparecidos en años anteriores denominados SARS (Severe Acute Respiratory Syndrome) que, desde noviembre de 2002 hasta finales de junio de 2003, produjo 8.422 casos y 916 defunciones en 29 países de los cinco continentes. $Y$ también MERS (Síndrome Respiratorio de Oriente Medio), que se reportó por primera vez en Arabia Saudita en 2012, enfermedad zoonótica procedente de los dromedarios.

Los Coronavirus forman una importante familia de virus, muchos de los cuales no son patógenos para los humanos. Pero desde los años sesenta del siglo pasado, tenemos varios Coronavirus conviviendo con nosotros/as y produciendo patologías en las vías respiratorias altas y a veces también en las bajas. Se trata de los serotipos 229E, y OC43, HKU1, NL63 y son responsables de algunos brotes del resfriado común.

Posteriormente la OMS, con el fin de no estigmatizar a Wuhan asociándolo a una neumonía, le dio al virus el nombre de SARS-CoV-2, para diferenciarlo del anterior SARS-CoV-1 de 2002. Y a la enfermedad la denominó COVID-19.

Nunca se había avanzado tanto en el conocimiento de un patógeno y en la patología que produce, como ha ocurrido a lo largo de este último año con el virus y la patología que nos ocupa. Varias fueron las líneas principales de investigación que los científicos de todo el mundo abordaron para intentar solucionar el problema: la primera fue la búsqueda de técnicas de diagnóstico rápidas y sensibles que permitieran diagnosticar al virus; la segunda, buscar su procedencia y la forma de contagiarse, datos fundamentales para construir la prevención; la tercera, buscar una terapia adecuada; y la cuarta, buscar una vacuna que pudiera prevenir la infección. 
Hoy en día se sabe que la fuente de contagio más importante, y casi la única, es el aire que exhalamos contaminado y que la posibilidad de contagio por "fómites" 3 es muy baja o prácticamente inexistente.

La utilización de mascarillas y la distancia de separación de las personas son, por ahora, la mejor manera de prevenir el contagio. De todas formas, la utilización de geles para la higiene de las manos es una buena práctica para otras muchas infecciones.

\section{El tratamiento}

Se ha experimentado con el arsenal terapéutico existente en las farmacias. Antivirales como el antirretroviral (TARV) para el VIH, anti protozoarios como la cloroquina e hidroxicloroquina, antihelmínticos como la ivermectina, etc., han sido utilizados con regular o nulo éxito y se han investigado nuevas moléculas con el fin de encontrar el antiviral ideal que resolviera el problema.

La realidad es que el único principio activo autorizado, primero por la FDA (Agencia para los Alimentos y Medicamentos de Estados Unidos) y luego la EMA (Agencia Europea del Medicamento), ha sido el Remdesivir. Es un profármaco ${ }^{4}$ utilizado anteriormente para el tratamiento del ÉBOLA, que también actúa frente a otros virus inhibiendo una enzima, indispensable para su multiplicación.

El Remdesivir no es un buen fármaco, pues solo mejora en un $31 \%$ la clínica de los pacientes. Concretamente, "el tiempo medio hasta la mejoría clínica" fue de 11 días para los pacientes tratados con Remdesivir, frente a los 15 días en el grupo de pacientes que recibieron placebo".

En la actualidad, la terapia de la COVID-19 se basa en actuar frente a los efectos de inflamación generados por la "cascada de citoquinas" y controlar el proceso de coagulación masiva que se genera como consecuencia de la presencia del virus en el organismo. El Remdesivir, la Betametasona, la Heparina y sus derivados, entre otros, son medicamentos que disminuyen la letalidad de esta nueva enfermedad.
En la actualidad, la terapia de la COVID-19 se basa en actuar frente a los efectos de inflamación generados por la "cascada de citoquinas" y controlar el proceso de coagulación masiva que se genera como consecuencia de la presencia del virus en el organismo. El Remdesivir, la Betametasona, la Heparina y sus derivados, entre otros, son medicamentos que disminuyen la letalidad de esta nueva enfermedad.

\section{Las vacunas}

Es la primera vez que, en el corto espacio de tiempo de un año, se investigan, prueban, fabrican y aplican vacunas frente a una patología. Esto ha sido gracias a los avances en biotecnología.

Se han realizado por primera vez vacunas con RNA mensajero, una técnica que se estaba empleando para la terapia del cáncer. En la actualidad se están aplicando varias vacunas, todas ellas sintéticas, que estimulan la generación de anticuerpos contra la proteína de la espícula, proteína que utiliza el virus para penetrar en las células.

Mientras no haya un tratamiento adecuado, las vacunas son la gran esperanza y la única solución a esta pandemia.

\section{La COVID-19 en San Cristóbal de La Laguna}

San Cristóbal de La Laguna es Ciudad Patrimonio de la Humanidad, municipio cosmopolita, universitario, turístico por sus múltiples atractivos. Por sus calles pasean, no solo los laguneros y laguneras, sino muchas de las personas de las localidades próximas y también visitantes venidos de muchas partes del mundo. Si tenemos en cuenta que la movilidad es la principal causa de la dispersión del virus, podremos entender que el municipio y su centro urbano eran candidatos a tener COVID en su población. El primer caso de COVID-19 en el municipio apareció el 5 de marzo de 2020, continuando el día 6 con dos casos más. 
Como se puede observar en el gráfico que se adjunta, la primera ola comenzó el 11 de marzo, llegando a su término la semana del 28 de abril, presentándose casos sueltos hasta el 29 de mayo. El 18 de marzo fue el día que más casos confirmados hubo en esta primera ola, con 19.

A partir de ahí, parecía que el municipio estaría exento de nuevos casos y hasta el 9 de julio, que comenzaron a aparecer algunos casos aislados, se tenía la tranquilidad de estar sin COVID-19. El principio de la segunda ola vino casi sin darnos cuenta a principio de los meses del último verano.

Esta segunda ola fue más fuerte que la primera y vino como consecuencia de la llegada del verano, el posterior regreso del alumnado universitario y el aumento de la actividad empresarial. Los meses de octubre, noviembre y diciembre fueron los que más casos positivos reportaron con 564, 564 y 633, respectivamente.
Para darnos cuenta de la importancia que este número de casos ha tenido, debemos analizar los datos generales del comportamiento que el virus tiene en cuanto a salud. De cada 1.000 personas que se infectan con el virus, unas 800 pasan por asintomáticas, por lo que unas 200 presentarán síntomas. De éstas, unas 150 necesitarán hospitalización; y un 16\% de estas últimas ingresarán en la $\mathrm{UCl}$. De las personas que entran en UCI por COVID-19, fallecen entre el 23 y el $28 \%$, es decir, casi una de cada cuatro.

\section{Evolución de la COVID-19 entre 18 -1 2021 en San Cristóbal de La Laguna}

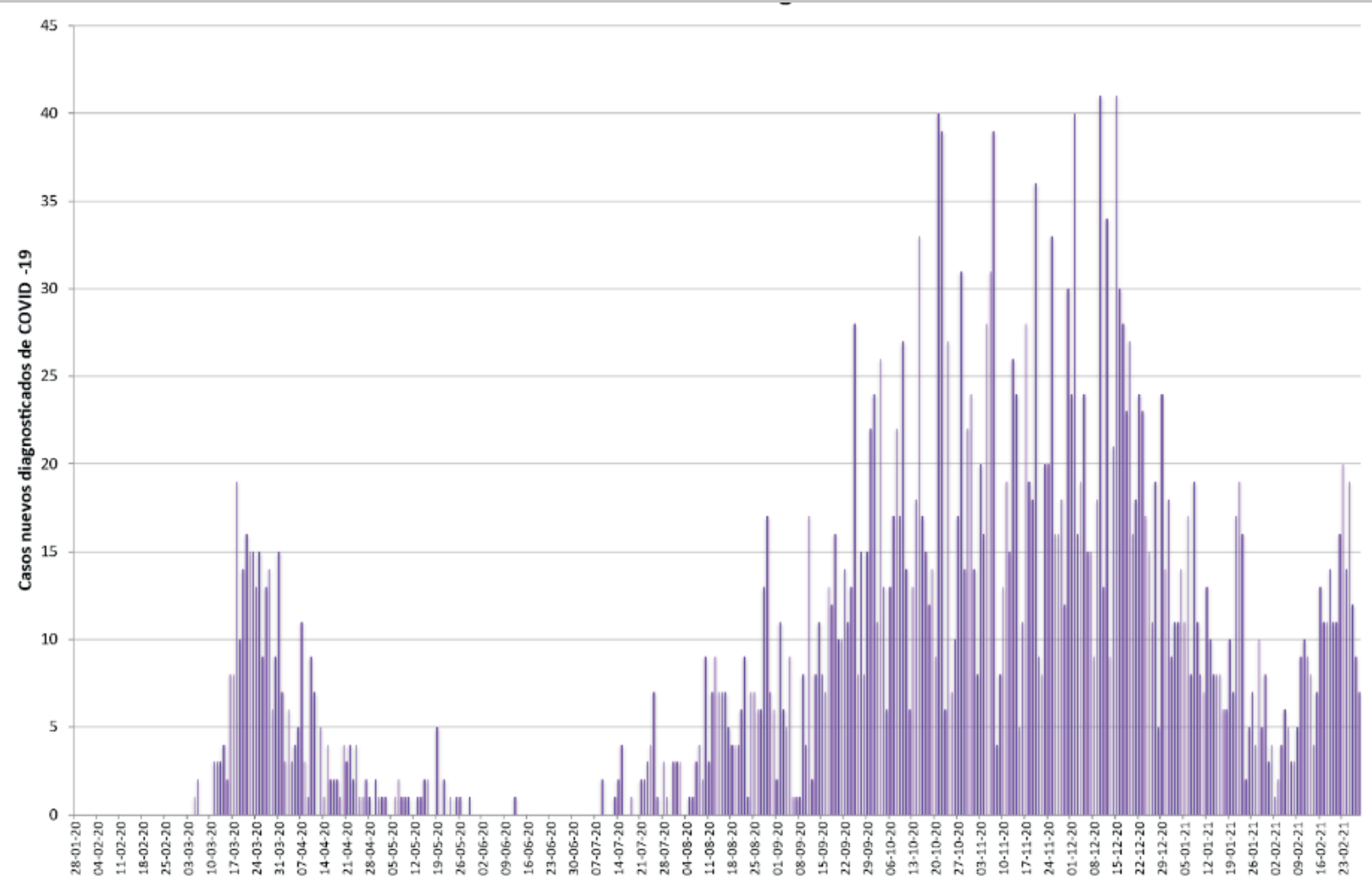

Fuente: Epidemiología de la Dirección General de Salud Pública del Gobierno de Canarias. Elaboración de Dr. Domingo Núñez Gallo y Eneko Elarzabal. 
La presencia del SARS-CoV-2 en San Cristóbal de La Laguna, entre los meses de febrero de 2020 a febrero de 2021, ha dejado un total de 5.158 positivos y de 162 personas fallecidas. Si se atiende a los casos positivos acumulados, ha tenido una ligera prevalencia en el grupo de mujeres $(51,2 \%)$ sobre el de hombres. Igual, aunque ha estado presente en todos los grupos de edad, la mayoría se han concentrado entre los 20 y 59 años, siendo el grupo de edad mayoritario el de 40-49 años. Sin embargo, si se atiende al peso específico de cada grupo de edad en el conjunto poblacional, han sido en el grupo de 80 y más años donde mayor impacto ha tenido. Siete de cada 100 personas mayores de 80 años han contraído la COVID-19.

Si se atiende a las personas fallecidas, a diferencia de los casos positivos, son los hombres los que más han registrado fallecimientos (56,3\%) en comparación con las mujeres. Considerando los grupos de edad, no se han registrado fallecimientos por COVID-19 en edades menores de 30 años, sin embargo, aumenta progresivamente a medida que se avanza en la edad. Casi el $60 \%$ de los fallecimientos se ha concentrado en el grupo de 80 y más años. Junto con el grupo de $70-79$ años, acumulan el $84 \%$ de las muertes por COVID-19 en el municipio.

De hecho, esta concentración ha sido patente en la mortalidad por casos activos que se ha registrado. Dos de cada diez personas que contrajeron la enfermedad con 80 y más años han fallecido. Uno de cada diez entre los 70 y 79 años. Poco más del $4 \%$ de la población lagunera se ha infectado con la COVID-19. De las personas infectadas, casi tres de cada cien han fallecido. El año de pandemia ha supuesto para San Cristóbal de La Laguna una muerte por cada mil personas. 
Incidencia de la COVID-19 por grupo de edad a 1 de marzo de 2021 en San Cristóbal de La Laguna

\begin{tabular}{|c|c|c|c|}
\hline Edad (años) & Casos positivos(\%) & Impacto en la población(\%) & Mortalidad sobre casos activos(\%) \\
\hline $\mathbf{0 - 9}$ & 5,3 & 3,1 & 0,0 \\
\hline $\mathbf{1 0 - 1 9}$ & 11,7 & 5,0 & 0,0 \\
\hline $\mathbf{2 0 - 2 9}$ & 13,4 & 4,6 & 0,0 \\
\hline $\mathbf{3 0 - 3 9}$ & 13,7 & 4,1 & 0,3 \\
\hline $\mathbf{4 0 - 4 9}$ & 15,7 & 3,9 & 0,4 \\
\hline $\mathbf{5 0 - 5 9}$ & 14,7 & 3,9 & 0,9 \\
\hline $\mathbf{6 0 - 6 9}$ & 10,4 & 4,0 & 2,1 \\
\hline $\mathbf{7 0 - 7 9}$ & 7,4 & 4,3 & 10,0 \\
\hline $\mathbf{8 0} \mathbf{y}$ & 7,5 & 7,3 & 21,8 \\
\hline Total & & 4,3 & 2,8 \\
\hline
\end{tabular}

Distribución de las personas fallecidas por la COVID-19 por grupo de edad a 1 de marzo de 2021 en San Cristóbal de La Laguna

\begin{tabular}{|c|c|c|c|}
\hline Edad (años) & Personas fallecidas \% & Hombres \% & Mujeres \% \\
\hline $\mathbf{0 - 9}$ & 0,0 & 0,0 & 0,0 \\
\hline $\mathbf{1 0 - 1 9}$ & 0,0 & 0,0 & 0,0 \\
\hline $\mathbf{2 0 - 2 9}$ & 0,0 & 0,0 & 0,0 \\
\hline $\mathbf{3 0 - 3 9}$ & 1,6 & 0,9 & 2,4 \\
\hline $\mathbf{4 0 - 4 9}$ & 2,1 & 1,9 & 2,4 \\
\hline $\mathbf{5 0 - 5 9}$ & 4,7 & 2,8 & 7,1 \\
\hline $\mathbf{6 0 - 6 9}$ & 7,8 & 12,0 & 2,4 \\
\hline $\mathbf{7 0 - 7 9}$ & 26,0 & 26,9 & 25,0 \\
\hline $\mathbf{8 0} \mathbf{y}$ & 57,8 & 55,6 & 60,7 \\
\hline Total & 100,0 & 56,3 & 43,8 \\
\hline
\end{tabular}



Ante la densidad de la información presentada, las medidas se clasifican según el territorio al que afectan (diferenciando entre estatal, autonómico, provincial, insular o municipal), así como el ámbito al que hacen referencia (restricciones de movilidad, acceso a los espacios públicos, higiene y medidas de protección individual).

\section{Normativa a nivel estatal: centralizando las decisiones}

\section{El primer estado de alarma y la nueva normalidad}

Una de las características a tener en cuenta a la hora de comprender la situación jurídica de España en el último año es la centralización de las normativas. Una vez decretado el estado de alarma, la mayoría de las decisiones legales pasan a estar bajo el control del gobierno central. Las competencias de las autonomías se limitan a concretar ciertos aspectos según sus particularidades territoriales.

Por tanto, la normativa más importante al principio de la pandemia es el Real Decreto 463/2020, de 14 de marzo, por el que se declara el estado de alarma para la gestión de la situación de crisis sanitaria ocasionada por la COVID-19, pues con él se definen a escala nacional las medidas a seguir.

De forma general, lo más importante del decreto es la aplicación de un confinamiento nacional, que restringe de forma estricta la movilidad y el acceso a los espacios públicos. Las condiciones principales del mismo se pueden enumerar de la siguiente manera:
1) Confinamiento general por el cual las personas solo pueden salir de sus domicilios para actividades esenciales como la adquisición de alimentos, productos farmacéuticos y de primera necesidad; la asistencia a establecimientos sanitarios; el desplazamiento al lugar de trabajo para efectuar su prestación laboral, profesional o empresarial; o el retorno al lugar de residencia habitual ${ }^{5}$.

2) La educación pasa a ser telemática y todos los centros educativos, formales y no formales, de todos los niveles están cerrados.

3) Se suspende toda actividad comercial excepto en los establecimientos que ofrecen servicios de primera necesidad, como supermercados o farmacias. Las actividades de hostelería y restauración solo podían mantener sus servicios a domicilio
4) El mundo de la cultura también se paraliza: se cierran museos, bibliotecas y todo tipo de espacios donde se desarrollen espectáculos, tanto culturales como deportivos.

5) Se reducen los servicios de transporte al 50\% y solo se puede viajar por causas justificadas o de fuerza mayor.

6) Los trámites, plazos administrativos o de preinscripción quedan temporalmente suspendidos 6

7) La asistencia a los lugares de culto, así como las celebraciones civiles y religiosas, incluidas las fúnebres, se condicionan a las medidas sanitarias en un primer momento, pero se prohíben de forma total a partir del 29 de marzo?.

\footnotetext{
${ }^{5}$ Las excepciones se desarrollan en el artículo 7 del Real Decreto.

${ }^{6}$ Se desarrolla en el Real Decreto 4/2020, de 2 de abril, de medidas extraordinarias de carácter económico, financieras, fiscal y administrativas para afrontar la crisis provocada por el COVID-19

${ }^{7}$ Orden SND/298/2020, de 29 de marzo, por la que se establecen medidas excepcionales en relación con los velatorios y ceremonias fúnebres para limitar la propagación y el contagio por el COVID-19
} 
Con respecto a la protección individual y sanitaria, destaca la Orden SND/422/2020, de 19 de mayo, por la que se regulan las condiciones para el uso obligatorio de mascarilla durante la situación de crisis sanitaria ocasionada por la COVID-19. Con ella, se establece a nivel nacional, desde el 20 de mayo, el uso obligatorio de mascarilla en la vía pública.

Por otro lado, en lo que respecta al propio estado de alarma, pese a que las restricciones van cambiando, este se prorroga cada quince días, el máximo establecido por la ley, a través de cuatro decretos más, siendo el último el Real Decreto 555/2020, de 5 de junio, dado por finalizado el 21 de junio de 2020. En la tercera prórroga del estado de alarma (RD 514/2020, de 8 de mayo), se incluye, por primera vez, la posibilidad de implementar el Plan de desescalada nacional, aprobado por el Consejo de Ministros el 28 de abril. Este se divide en cuatro fases, que se van aplicando a las diferentes unidades territoriales de forma independiente y coordinada, acorde al cumplimiento de unos parámetros determinados: los relativos a la salud pública, los de movilidad, los que atienden a la dimensión social y los de la actividad económica. Las cuatro fases se resumieron en lo siguiente:

Fase 0 (o de preparación de la desescalada)

Los diferentes comercios relativos a la hostelería pueden abrir para realizar repartos a domicilio, y otros locales como las peluquerías o tintorerías pueden atender con cita previa. También pueden abrir tiendas como las librerías o zapaterías con medidas de protección y limitación de aforo. En lo que respecta al confinamiento, se establecen diferentes franjas horarias para salir a pasear o hacer deporte, divididas por edad y solo pudiendo ir acompañadas de personas convivientes.

\section{Fase 1}

Se permiten las visitas que no sean a personas mayores ni tengan patologías previas siempre que vivan en la misma provincia, y con un límite de 10 personas manteniendo las recomendaciones sanitarias. El resto de comercios abren y la restauración y hostelería puede habilitar las terrazas con una limitación de aforo del 50\%. Asimismo, se comienza una reactivación progresiva de los servicios sociales.

\section{Fase 2}

Los comercios abren con un aforo al 40\%, y la restauración puede admitir clientes en el interior, pero con el aforo a la mitad. Se reincorporan a los centros educativos los grupos de $4^{\circ}$ ESO, $2^{\circ}$ Bachillerato, Formación Profesional medio y superior y el último año de enseñanzas de régimen especial; podrán volver alternando grupos de no más de 15 estudiantes. También abren los cines, teatros y auditorios, así como los monumentos o exposiciones, igual que los centros religiosos, todos con límites de aforo y guardando las medidas de distanciamiento físico.

\section{Fase 3}

Además de otras medidas, se permiten los viajes entre provincias que estén en la fase 3, y por primera vez, se admiten visitas a las residencias de mayores salvaguardando todas las medidas sanitarias.

De esta manera, las diferentes unidades territoriales van progresando a través de las diferentes fases, con un mínimo de dos semanas cada una, hasta que el estado de alarma finaliza el 21 de junio, y todo se desenvuelve en una "nueva normalidad", durante la cual los poderes públicos y las autoridades sanitarias continuaron tomando medidas dirigidas a controlar los brotes y frenar los contagios. Una de ellas fue el Real Decreto 21/2020, de 9 de junio, de medidas urgentes de prevención, contención y coordinación para hacer frente a la crisis sanitaria ocasionada por la COVID-19, con la que regulan las medidas sociosanitarias individuales y comerciales, bajo las cuales se desarrolla la nueva normalidad. Estas medidas rigen desde el uso de mascarilla, a los diferentes volúmenes de aforo en el transporte o las condiciones para realizar actividades deportivas. 


\section{El segundo estado de alarma}

Tras superar los meses de confinamiento con el impacto que supuso a nivel económico y social, las comunidades autónomas fueron avanzando a través de las fases de desescalada y la población disfrutaba de un verano algo más relajado. Sin embargo, en octubre, las cifras de contagios aumentan de manera alarmante y la inquietud por la llegada de una segunda ola da lugar a la declaración del segundo estado de alarma, regulado por el Real Decreto 926/2020, de 25 de octubre, por el que se declara el estado de alarma para contener la propagación de infecciones causadas por el SARS-CoV-2. En otras palabras, a través del segundo estado de alarma, todas las comunidades autónomas deben atenerse a las mismas restricciones, pero el grado de severidad de las mismas puede variar según la situación sanitaria de cada una. Las principales regulaciones de este Real Decreto se resumen de la siguiente manera:
Este segundo estado de alarma se prorroga finalmente hasta el 9 de mayo de 2021 (Real Decreto 956/2020, de 3 de noviembre), para tratar de asegurar que, bajo la supervisión y coordinación del Gobierno central, las diferentes comunidades gestionen la situación en cada territorio.

De este modo, entendemos que, en el principio de la pandemia, todas las decisiones están a cargo del gobierno central, pero una vez el confinamiento más estricto finaliza, y comienza la desescalada por fases, se delega cada vez más competencias en las Comunidades Autónomas.

\section{1) Restricción de la libertad de}

movimiento entre las 23:00 y las 6:00 horas. Aunque cada autonomía podía modular la hora de comienzo (de 22:00 a 00:00) y la de finalización (5:00 a 07:00). En un primer momento, Canarias quedó excluida de esta norma (art. 5, RD 926/2020).

\section{2) No se puede salir del ámbito}

autonómico. Incluso, esta restricción puede ser reducida a ámbitos territoriales de carácter geográficamente inferior, como provincias, municipios... No obstante, contempla varias excepciones como, por ejemplo, la asistencia a centros, servicios y establecimientos sanitarios, el retorno al lugar de residencia habitual o familiar o la realización de exámenes o pruebas oficiales inaplazables ${ }^{8}$.

\section{3) Se limita la permanencia de grupos de} personas en espacios públicos y privados a seis personas si no son convivientes, pudiendo ser reducida la cifra por las autoridades delegadas competentes. Asimismo, se restringe la permanencia de grupos e individuos en lugares de culto y/o celebraciones religiosas.

${ }^{8}$ Las excepciones se desarrollan en el artículo 6 del mismo Real Decreto. 


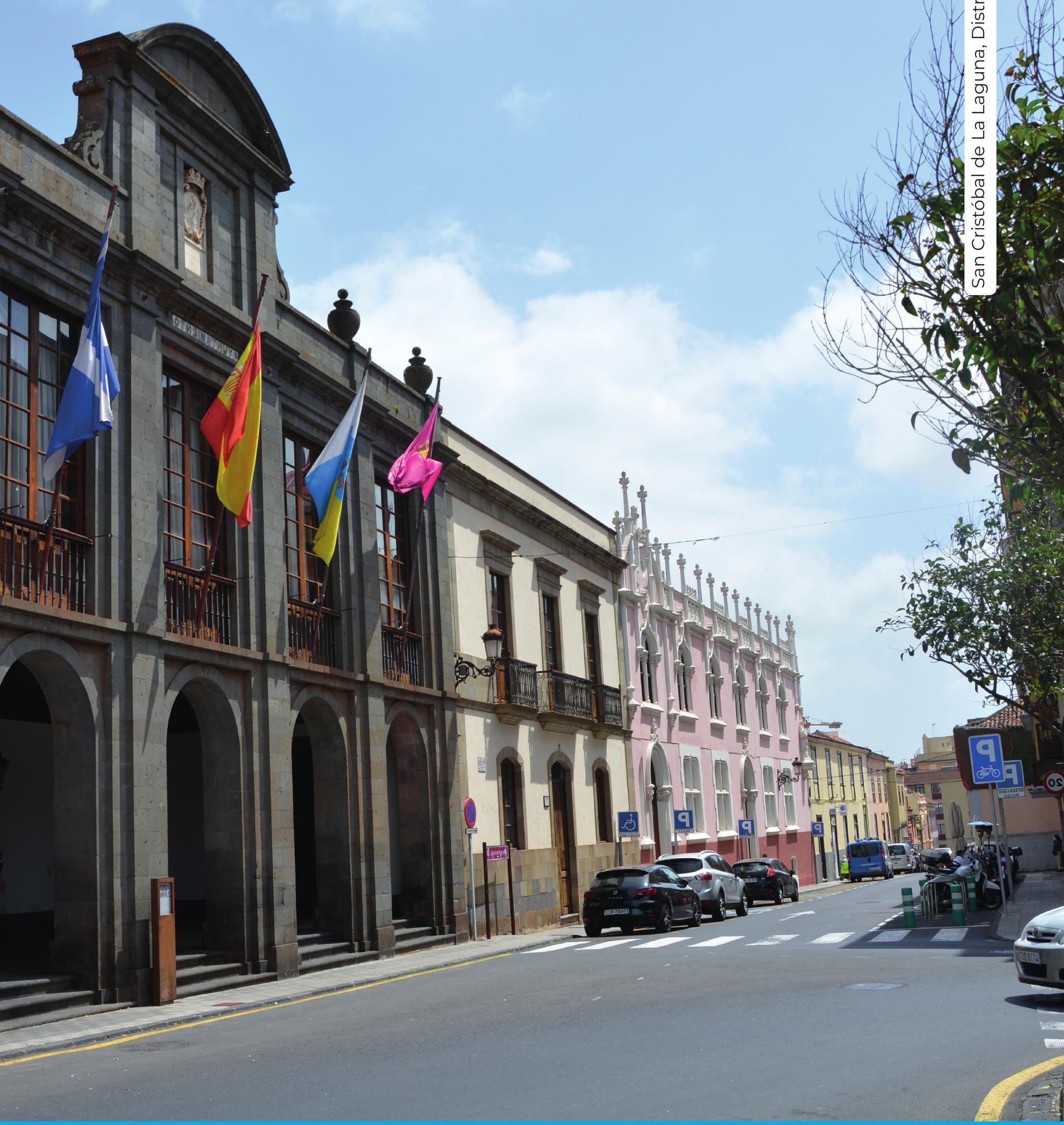


Normativa a nivel autonómico: concretando el estado de alarma Periodo del confinamiento y fases de la desescalada

En lo que se refiere a la normativa autonómica, es necesario destacar que las leyes y regulaciones emanadas desde el Gobierno de Canarias, han quedado supeditadas desde marzo de 2020 a las decisiones del Gobierno central y las implicaciones del estado de alarma que se explican en el apartado anterior. Por esta razón, la normativa que se redacta desde la institución autonómica, está dirigida a adaptar las leyes generales a la situación del archipiélago. De esta manera, podemos enumerar varios ejemplos de estas normas, que afectaron de una manera particular a la sociedad canaria con respecto a la movilidad, el acceso a los espacios públicos o las medidas sociosanitarias:

a) Medidas sobre la regularización y limitación del transporte marítimo y aéreo: el Decreto 25/2020, de 17 de marzo, y el Decreto 28/2020, de 18 de marzo, establece las condiciones con respecto a la conectividad marítima o aérea de las Islas. En los decretos se reduce la frecuencia de los trayectos al 50\% y se definen las situaciones excepcionales en las que sí se permite viajar, como la asistencia a centros sanitarios, el cumplimiento de obligaciones laborales, el retorno al lugar de residencia habitual o cualquier causa de fuerza mayor, entre otras.

b) A la limitación en el tránsito, se añaden los controles a los pasajeros, lo cual fue evolucionando, pasando de simples controles de temperatura a las pruebas rápidas de detección de antígenos (resolución de 14 de octubre de 2020). Esta medida cambia según avanza la investigación sobre el virus y los métodos de detección, de ahí que, meses más tarde, mediante la Orden de 14 de diciembre de 2020, se disponga la realización de cribados mediante pruebas diagnósticas de infección activa (PDIA) a los pasajeros y pasajeras que entren en el territorio de la Comunidad Autónoma de Canarias.
También destaca la acción autonómica una vez que se puso en marcha el Plan de Desescalada:

La fase III supuso la posibilidad de realizar muchas de las actividades suspendidas desde febrero de 2020. Poco a poco las restricciones fueron desapareciendo y se levantó el estado de alarma. Sin embargo, "la recuperación [...] debe hacerse en todo caso de forma gradual, progresiva y prudente, para evitar retrocesos que serían muy perjudiciales" (preámbulo, Decreto 49/2020).

Por esta razón, el Gobierno de Canarias decidió, mediante el decreto 49/2020, de 8 de junio, del Presidente, "la no reapertura de los locales de discotecas y bares de ocio nocturno". Esta fue solo una de las medidas que se establecieron para que la reapertura no provocara de nuevo el cierre total. Muchas otras se recogen en resoluciones como la del 19 de junio de 2020, "por la que se dispone la publicación del Acuerdo por el que se establecen medidas de prevención para hacer frente a la crisis sanitaria ocasionada por el COVID-19, una vez superada la fase III del plan para la transición hacia una nueva normalidad, finalizada la vigencia de las medidas propias del estado de alarma".

Ahí se concretan restricciones específicas para las Islas, sobre todo con respecto al protocolo sociosanitario y de control que se deben cumplir en las diferentes actividades. Todas parten de un principio de cautela ciudadana y autoprotección, por la que se presupone que la sociedad canaria tiene una responsabilidad clave en cómo evolucionen las cifras sanitarias. Igualmente se definen las normas de aforo, limpieza y desinfección aplicables a todas las actividades. Por ejemplo: la preferencia por las cartas de los menús digitalizados en la hostelería y restauración, los itinerarios de salida y entrada en las tiendas, o el uso obligatorio de mascarilla.

De esta manera, el verano de 2020 avanza y la situación pandémica en Canarias parece favorable, posicionándose como uno de los destinos más seguros de Europa y disfrutando de restricciones mucho más flexibles que en el resto del territorio nacional. 


\section{Empeoramiento de la situación sanitaria en el archipiélago y endurecimiento de las restricciones}

La visión positiva en relación con la situación pandémica en Canarias cambia tras el verano de 2020, cuando las cifras de contagios vuelven a subir de manera alarmante e islas como Gran Canaria pasan por situaciones críticas durante algunas semanas, seguida de Tenerife con la misma tendencia. Esto provoca el endurecimiento de las medidas vigentes a principios de diciembre, coincidiendo con la cercanía de periodos vacacionales importantes.

Una de las medidas que se aplican es el Decreto 87/2020, de 9 de diciembre, del Presidente, en el que la comunidad autónoma declara un cierre perimetral respecto al resto del país. En tiempos de pandemia, celebraciones como la Navidad se convierten en un desafío, tanto a nivel personal como político. La duda de cómo regular unas fiestas tan familiares y cercanas supone un gran reto a las instituciones, pues el riesgo de que los contagios aumenten debido a las reuniones y fiestas, se cruza con la responsabilidad que supone separar a las familias en unos días tan especiales, después de un año tan duro.

Otra de las medidas es el Decreto 84/2020, de 3 de diciembre, del Presidente, "por el que se establecen medidas específicas para la celebración de las Fiestas Navideñas en el ámbito de la Comunidad Autónoma de Canarias", como una concreción autonómica del Real Decreto 926/2020, con el que se establece el segundo estado de alarma a nivel nacional. Tratan de adoptar ciertas restricciones cuyo impacto tenga la menor repercusión en los comercios:
Las restricciones navideñas debían finalizar el 10 de enero, sin embargo, la situación de algunas islas como Tenerife sigue siendo crítica, y por miedo a los rebrotes y a la saturación del sistema sanitario, se instaura de manera oficial el sistema de alerta territorial, el cual establece una serie de indicadores que determinan las capacidades de preparación y reacción que deben tener todas las comunidades ante un aumento de los contagios. Asimismo, se detalla una clasificación en cuatro niveles, según la situación sociosanitaria de cada territorio. Cada nivel conlleva una serie de restricciones:

Nivel 1: la libre circulación de personas se limita desde las 00:00 a las 6:00 horas. Por otro lado, los grupos son máximo de 6 personas, salvo convivientes. Las terrazas pueden ocuparse al 100\%, pero el interior al 75\%; y este aforo se repite en los lugares de culto. Se puede hacer deporte en grupo, cumpliendo con las medidas de distanciamiento.

Nivel 2: el toque de queda se adelanta a las 23:00 horas, y los grupos se reducen a 4 como máximo, lo cual afecta también a los grupos para realizar deporte. Los aforos también cambian, siendo las terrazas al $75 \%$ y el interior al $50 \%$, aforo que se aplica también al transporte y a los lugares de culto. Las visitas a hospitales y centros sociosanitarios también comienzan a supervisarse.

Nivel 3: las personas solo pueden acceder al espacio público con convivientes, excepto en el ámbito de la hostelería, donde pueden reunirse hasta cuatro. Sin embargo, el toque de queda se adelanta a las 22:00 horas, las terrazas al 50\% del aforo y el interior de los locales queda cerrado al público. El aforo en los lugares de culto se reduce al 33\%. Se prohíben las visitas a hospitales
1) Los grupos no pueden superar las 10 personas en caso de convivientes, de lo contrario, su máximo es de 6.
2) Se establece el primer toque de queda en la comunidad, desde la 1:00 a las 6:00 horas, exceptuando los días 24 y 25 de diciembre, así como la noche del 31, en la que el toque de queda se retrasa media hora.

${ }^{9}$ El sistema de alerta nacional se puede encontrar originalmente en el Plan de respuesta en un escenario de control de la pandemia por Covid-19 (Consejo Interterritorial del Sistema Nacional de Salud), y desarrollado de forma técnica en el documento "Actuaciones de respuesta coordinada para el control de la transmisión de Covid - 19". En lo que respecta a la normativa autonómica, aparece en el acuerdo de Gobierno de 21 de enero de 2021, por el que se actualiza el acuerdo de 19 de junio. 
y el deporte en interiores, y en exteriores solo se permite individualmente. Asimismo, se restringe la salida y entrada de la isla, y los locales de apuestas y recreativos permanecen cerrados.

Nivel 4: este nivel se diferencia del tercero en el máximo de personas por grupo, que se reduce a 2. Además, los congresos, las juntas o las reuniones solo se realizan telemáticamente.

Este sistema de alerta sigue vigente en febrero de 2021, al amparo del segundo estado de alarma nacional. Tras las fiestas navideñas, la autonomía tiene que decidir su método de actuación con respecto a otra fiesta emblemática como es el Carnaval 2021. Por primera vez en décadas, no solo se cancelan todos los espectáculos, celebraciones masivas y concursos, sino que también se dictan otras medidas que tratan de prevenir conductas individuales o grupales que puedan poner en peligro la situación sanitaria de las Islas. Las restricciones comienzan el
12 de febrero, tras la publicación de la resolución de 11 de febrero de 2021, "por la que se dispone la publicación del Acuerdo que aprueba medidas específicas y temporales, en el ámbito de la Comunidad Autónoma de Canarias, durante el periodo de las consideradas tradicionalmente como "Fiestas de Carnaval" en el año 2021". Las limitaciones se aplican hasta el 22 de febrero, y se basan sobre todo en limitar la libertad de circulación de las personas en horario nocturno, con independencia del nivel de alerta en que se encuentre cada una de las islas, entre las 22:00 y las 6:00 horas. Además, se prohíben las fiestas, espectáculos o verbenas; en la restauración y la hostelería se restringe el consumo en barra, o fuera de la mesa, así como las actividades que propicien aglomeraciones o un uso incorrecto de mascarillas, como los bailes, karaokes, concursos, conciertos o música ambiental que inviten a bailar o cantar.

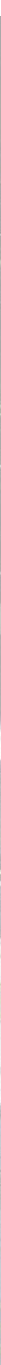




\section{Normativa a nivel insular: del Cabildo al Ayuntamiento}

En este último epígrafe, se enumera la normativa aplicada en los niveles más próximos a la ciudadanía, desde administraciones públicas como el Cabildo de Tenerife y el Ayuntamiento de San Cristóbal de La Laguna. Cabe destacar que a medida que se reduce el ámbito territorial, el volumen de normativa va disminuyendo, pues muchas de las decisiones están regladas por un ámbito institucional mayor. En el caso de Tenerife, se encuentran normativas dirigidas a regular aspectos muy concretos de la isla, pues la mayoría de restricciones estaban ya dictadas por las leyes autonómicas y estatales.

Estas concreciones se ejemplifican en regulaciones como el Decreto del Presidente, de 14 de marzo, "por el que se establece en la isla de Tenerife medidas excepcionales adicionales derivadas de la emergencia sanitaria motivadas por el brote." Con él, se aplica el cierre de la red de senderos, el teleférico del Teide, los accesos al monte, los parques insulares, así como muchos otros espacios públicos.

Avanzado el año 2020, el Gobierno de Canarias es protagonista cuando la situación sanitaria en Tenerife se complica. En esta etapa se declara el nivel tres de alerta en la isla, y las medidas pasan a ser aún más restrictivas, lo cual se recoge en resoluciones como la de 12 de noviembre de 2020, "por la que se dispone la publicación del Acuerdo por el que se establecen, en el ámbito de la isla de Tenerife, las medidas urgentes de carácter extraordinario y temporal, de prevención y contención necesarias para hacer frente a la crisis sanitaria ocasionada por el COVID-19".

Por último, es importante conocer la realidad que se ha vivido desde el Ayuntamiento del municipio de San Cristóbal de La Laguna, como el ámbito más cercano a la vecindad. Aquí es importante el papel de los bandos, desde los que recomiendan medidas a seguir por parte de la ciudadanía, como el Bando de 24 de abril, relativo al desconfinamiento de las personas menores, o el de 1 de mayo, donde se formulan las recomendaciones que deberán respetarse en la fase 0 de preparación de la desescalada.
Los bandos también pueden autorizar normativas temporales, como los de 11 y 13 de mayo. En el primero se permite temporalmente la ocupación del dominio público para ampliar las terrazas con mesas y sillas; y en el segundo se concretan las especificaciones por las que se puede acceder a la autorización y las condiciones para llevarla a cabo. Estos se complementan con los Bandos del 18 de mayo, que extiende la autorización a la calle Heraclio Sánchez, y el de 26 de mayo, a las calles Tizón y Bencomo.

No obstante, los bandos pueden servir como limitaciones, como por ejemplo el del 19 de junio, con el que se prohíbe realizar hogueras durante las vísperas de la festividad de San Juan y de San Pedro en espacios públicos, playas y zonas de baño del litoral del municipio; el del 20 de diciembre, con el que se cierran los Complejos Deportivos de Taco, La Cuesta y San Benito; o el del 11 de noviembre, que plantea el aplazamiento o suspensión de todas las actividades o actos lúdicos previstos y organizados por el Ayuntamiento lagunero, que supongan la aglomeración de muchas personas y con ello el riesgo de rebrotes.

Como resumen, podemos entender que, con la declaración de los estados de alarma, la mayoría de los poderes políticos y jurídicos se centralizan. No obstante, las instituciones autonómicas y locales han ido ganando cada vez más poder de decisión, lo que permite la flexibilización o rigidez de las medidas en función del territorio y no de la situación que se observa en la escala estatal. 


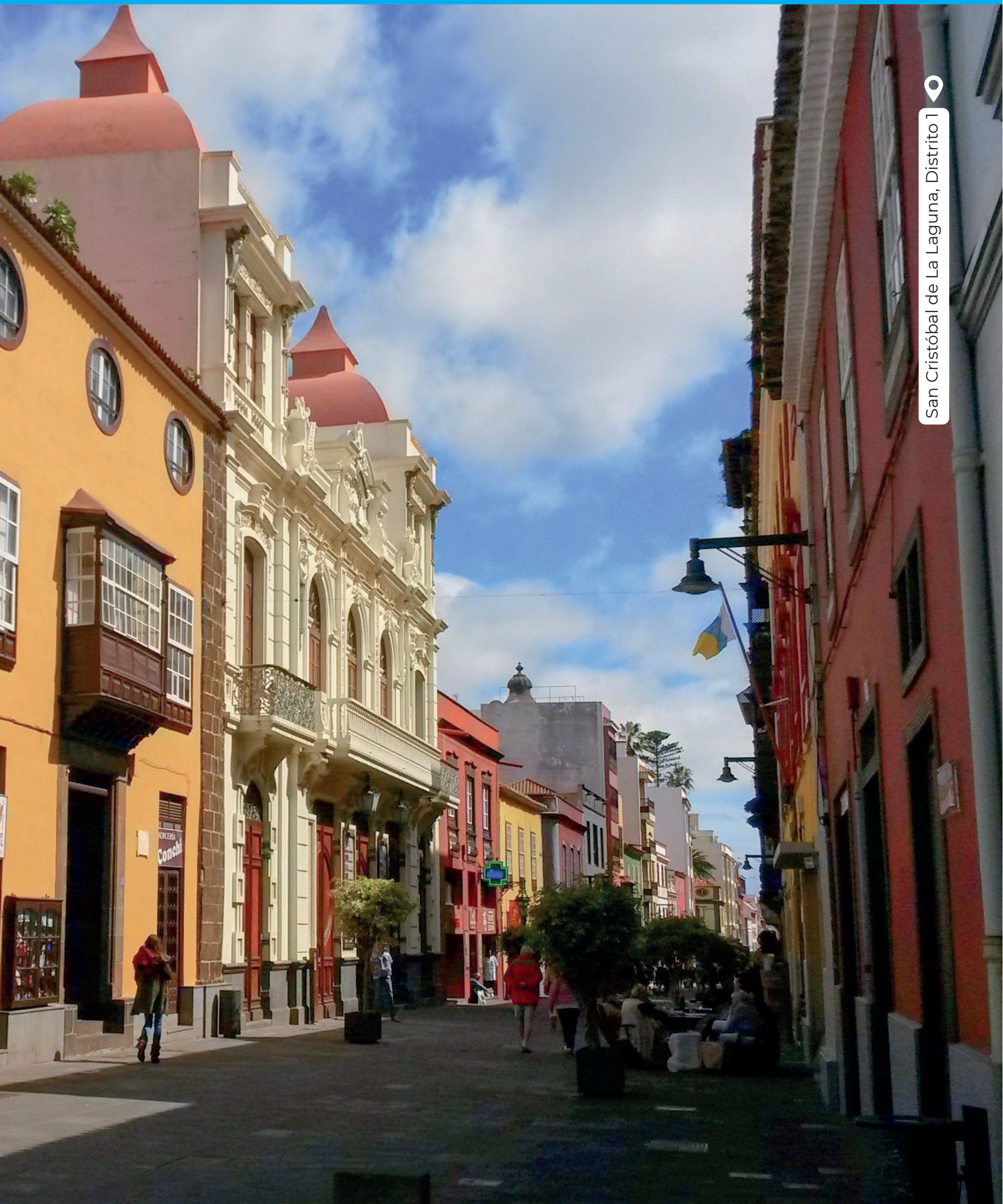





\section{La mirada de la comunidad: \\ La información subjetiva}


La parte subjetiva de la Monografía Comunitaria "La COVID-19 en San Cristóbal de La Laguna: una mirada desde la comunidad" recoge toda aquella información que se extrae del Proceso de Audición, o lo que es lo mismo, de las escuchas que se han realizado a las diferentes personas de la comunidad.

Como se ha explicado en el apartado metodológico, la información recabada ha sido copiosa y se ha optado por hacer un análisis sobre aquellos ámbitos sectoriales que más se vinculan con la esfera de las políticas públicas. Además, se ha querido conocer cuáles han sido los impactos, tanto negativos como positivos, para poder poner la mirada en lo que ha supuesto el paso de la COVID-19 en el municipio. Pero no solo en lo que ha pasado, sino también en el futuro, en cuáles son las expectativas, tanto positivas como negativas, que ha generado.

Conocidos los impactos y las expectativas, el análisis se centra en los conflictos que se han generado en la comunidad durante el primer año de pandemia en el municipio. Tratando de avanzar un poco más, también se ha identificado qué experiencias se han convertido en aprendizajes y qué conflictos se han resuelto de manera positiva. Por último, el trabajo se centra en mostrar las diferentes propuestas de medidas y acciones que se han compartido, con el objetivo de generar una mejora de la situación actual y en los ámbitos a los que se refiere.

La Monografía Comunitaria permite conocer de manera ordenada y atendiendo a su prioridad lo que la comunidad expresa. Es decir, si se tiene en cuenta al conjunto de la población que compone la comunidad, la información puede ser tan variable como personas individuales existan. Sin embargo, la Monografía Comunitaria analiza y agrupa los relatos de tal manera que se muestra aquello que está presente de forma mayoritaria en el conjunto.

Bajo esta perspectiva, es necesario precisar que el análisis de la información no trata de ser excluyente de las realidades individuales, sino que pretende poner el foco de atención en las prioridades del conjunto de personas de la comunidad. Centra su análisis en el interés general más que en el particular, justificado por la prioridad de atender a las cuestiones más presentes que se comparten, sobre todo desde la potencial incidencia de las políticas públicas. Supera por lo tanto el plano individual, más propio de atenciones concretas y especializadas.

Solo dos aspectos singulares han sido motivo de análisis específico, y según se hayan reconocido diferencias, se han incluido en los resultados. Por un lado, la tipología del protagonista, es decir, los posibles relatos diferentes entre la ciudadanía, los/as recursos técnicos/as y profesionales y los/ as representantes institucionales. Por otro lado, el distrito municipal con el que se corresponden las personas que han sido escuchadas. 


\section{Los impactos en el municipio}
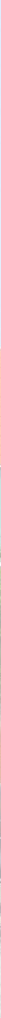
Los impactos cuentan qué ha sucedido en San Cristóbal de La Laguna en el periodo comprendido entre los meses de febrero de 2020 y 2021, aquello que se encuentra relacionado con la llegada de la COVID-19 y su presencia en el municipio. No solo centra el análisis en los aspectos negativos, que han sido muchos, sino también en los aspectos positivos que asimismo se han producido.

Los impactos recorren diferentes dimensiones que se han propuesto en el análisis, para tratar de comprender de una manera amplia el ámbito social en el que se desarrolla la comunidad y los sectores desde o sobre los que se organiza su acción. Desde la perspectiva más general, se incluye la dimensión Sociedad, que recoge aquellas cuestiones más vinculadas con las relaciones entre las personas, la cohesión social, la convivencia y los derechos sociales. Desde una perspectiva más sectorial, más orientada a campos de actuación de la acción social, se contemplan las dimensiones
Educación, Salud, Empleo, Economía, Servicios Sociales, Seguridad Ciudadana, Cultura, Deportey Ocio. Desde una perspectiva más conectada con el territorio, se recoge la dimensión Espacios Públicos.

No todas las dimensiones están reflejadas en cada apartado, como se ha mencionado anteriormente; únicamente se contemplan las agregaciones mayores, con el objetivo de identificar las prioridades de la comunidad. En este sentido, en el apartado de impactos se han recogido aquellos aspectos que han estado presentes, como mínimo, en el 10\% de todas las escuchas realizadas.
Relación entre impactos negativos y positivos identificados en el proceso de audición (\%)
Presencia en las escuchas realizadas de impactos negativos y positivos durante el
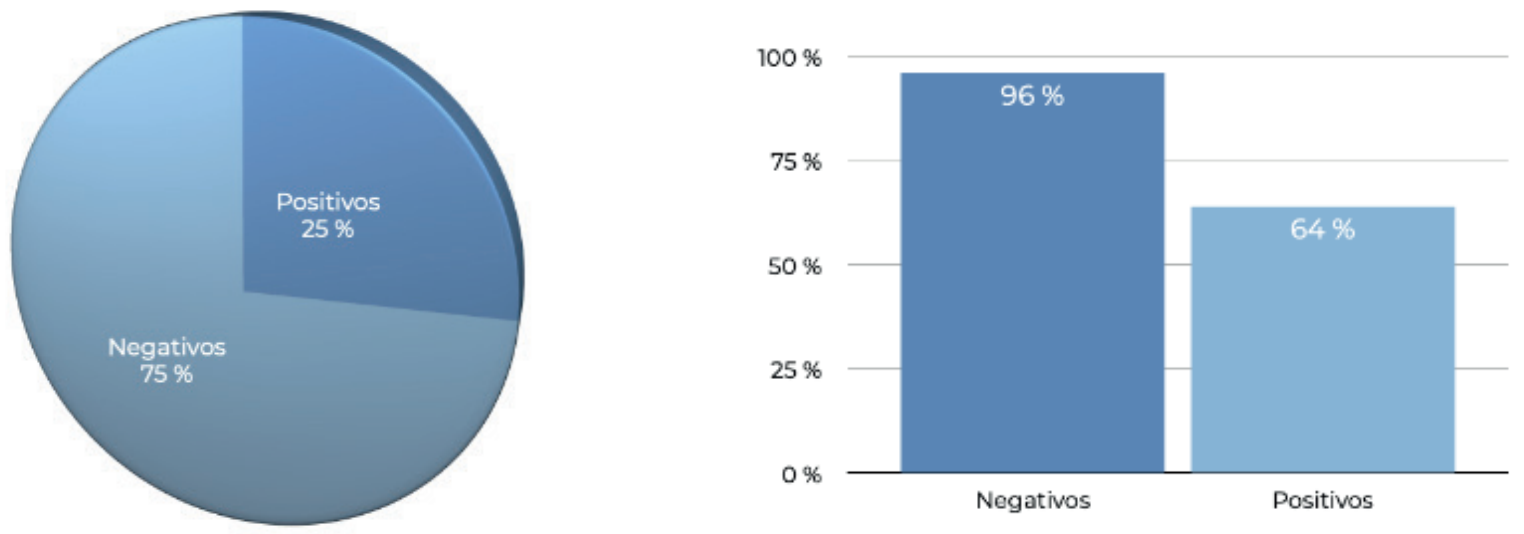

Fuente: Proceso de Audición del Proyecto Comunidad. Elaboración propia 
Relación de impactos negativos según dimensiones identificadas en el proceso de audición (\%).

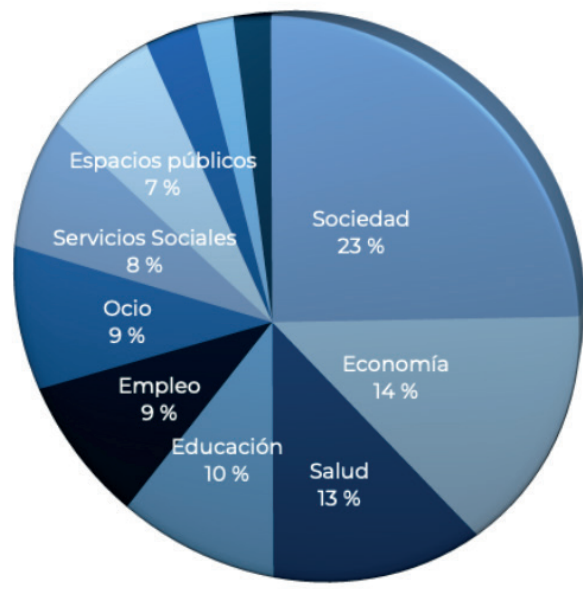

Fuente: Proceso de Audición del Proyecto Comunidad Elaboración propia

\section{Los impactos negativos}

Los impactos negativos están claramente identificados por la comunidad. Se confirma que el impacto de la COVID-19 es negativo y se distribuye, con diferentes grados de intensidad, entre todas las dimensiones sociales.

Los impactos negativos están presentes en 96 de cada 100 relatos escuchados, sin embargo, se concentran de manera dispar. Sociedad, Economía y Salud marcan los tres frentes principales de incidencia de la pandemia en el municipio y concentran los impactos negativos. Mientras que son menos relevantes, por lo menos desde la perspectiva comunitaria, aquellos acontecidos en Seguridad Ciudadana y Deporte, apareciendo en 7 de cada 100 relatos. A continuación se ordenan las dimensiones de mayor a menor, atendiendo a los relatos más reiterados.

$100 \%$

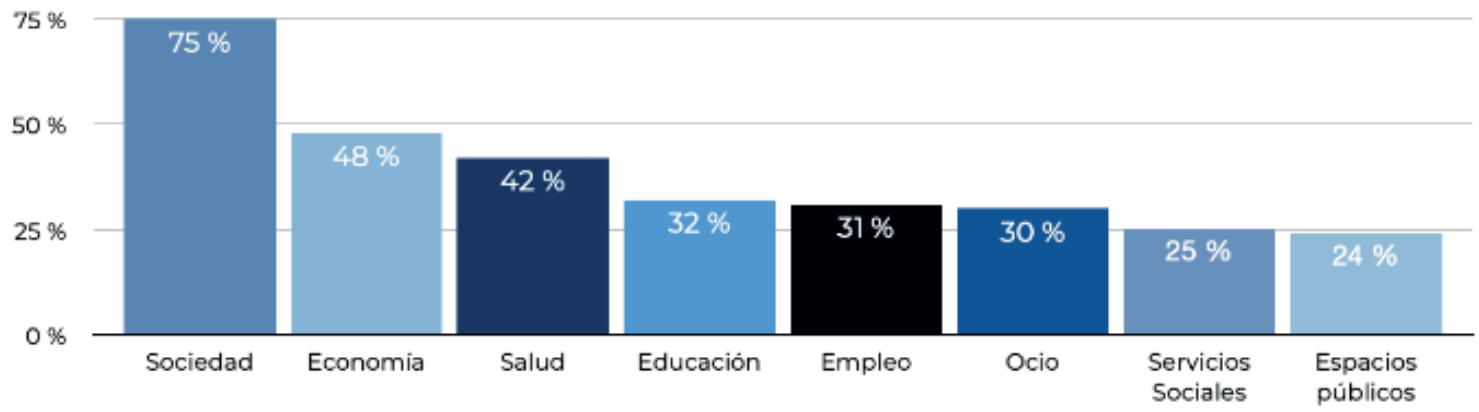

Fuente: Proceso de Audición del Proyecto Comunidad. Elaboración propia 


\section{Impactos negativos en la dimensión}

Sociedad identificados en el proceso de audición (\%)

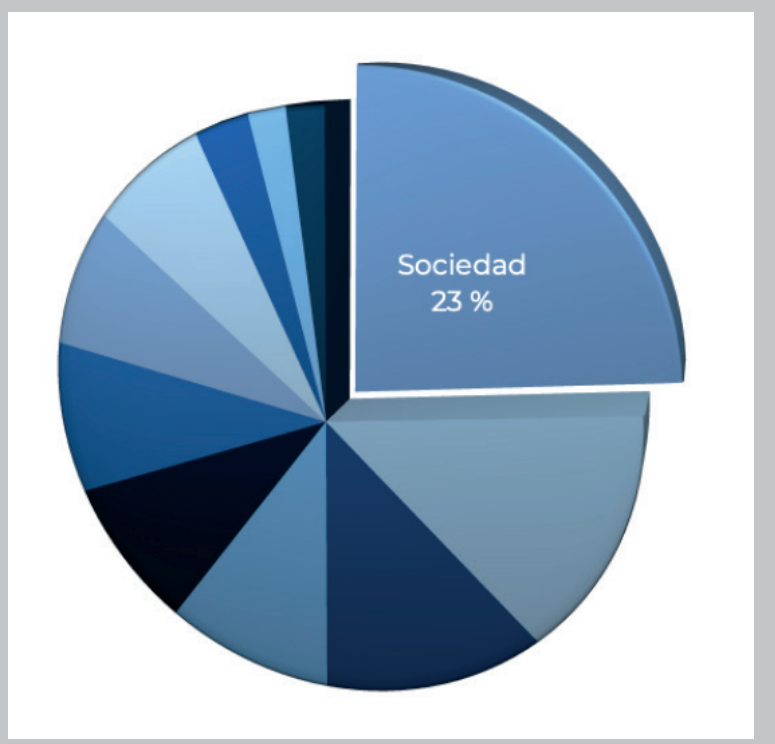

Fuente: Proceso de Audición del Proyecto Comunidad. Elaboración propia

\section{Sociedad}

Tres de cada cuatro personas han identificado un impacto negativo en la sociedad. En mayor medida, el impacto negativo hace referencia a la pérdida del contacto social originado por la pandemia, que se asocia en muchas ocasiones a la soledad sobrevenida por las circunstancias, por la imposibilidad de poder reunirse con las demás personas. También en los cambios que se experimentan a la hora de relacionarse e interactuar con la vecindad, amistades, familiares y compañeros y compañeras de estudio o de trabajo, sintiéndose las personas menos próximas y afectuosas que antes de la pandemia.
"En lo social, la COVID-19 ha afectado a las relaciones sociales, en especial a las personas mayores. El contacto es muy importante cuando nos encontramos en estas edades y se ha perdido; en algunos

casos ha generado estados de soledad

absoluta. En los adolescentes existe

un riesgo enorme de que se generen secuelas en la parte afectiva, ya que, por la pérdida de contacto, no se adquiere un aprendizaje importante para afrontar las relaciones personales"

Sindicato, distrito 2

Aunque se observa este impacto en todas las edades, se resalta, principalmente, en el deterioro que está causando a las personas mayores la soledad y también en el impacto que está generando esta nueva forma de relación para la infancia y la adolescencia, que parecen estar mostrando dificultades en la interacción social.

\begin{abstract}
"El impacto de la COVID-19 ha sido una ruina, a nosotros como asociación, que antes hacíamos de todo, vivíamos la vida de los mayores muy alegre, con excursiones, comidas, parrandas, actividades variadas. A día de hoy solo tenemos un grupo de WhatsApp para saludarnos y poco más"
\end{abstract}

Asociación de Mayores, distrito 5

Asimismo, la eliminación o disminución de las actividades que se realizaban habitualmente y con carácter diario se ha destacado como un impacto negativo. Las actividades hacen referencia tanto a las ofrecidas a la ciudadanía (por ejemplo, las clases impartidas en los Centros Ciudadanos), como a servicios que se desarrollaban desde las entidades en general (proyectos que quedaron paralizados por la pandemia), como actividades cotidianas del día a día de las personas (por ejemplo, ir a nadar, quedar para realizar alguna actividad, etc.). También se observa un impacto negativo en la dificultad para el manejo de las nuevas 
tecnologías, principalmente en lo referido a la brecha digital intergeneracional. Estas dificultades tecnológicas han supuesto un problema para las distintas actividades en las que se han empleado como medio de relación preferente, desde realizar gestiones administrativas, educativas y laborales, hasta su utilización como herramienta para el propio acercamiento social.

"La brecha digital se ha cebado mucho con las personas mayores, ya que los bancos y las administraciones están cerradas y ellas no se entienden con la tecnología. El confinamiento ha sacado a la luz que hay gente que no tiene ni conocimiento tecnológico ni los dispositivos necesarios, cosa de la que no nos habíamos dado cuenta"

Asociación de Jóvenes, distrito 3

Por último, se observa un por la COVID-19, principalmente por el temor al contagio y por todas las posibles consecuencias que trae la pandemia en el resto de ámbitos (empleo, economía, educación, etc.).
"Tenemos miedo y se crea miedo, debido a la falta de atención a la ciudadanía que estamos padeciendo. No se puede pedir a la ciudadanía que cumpla con las medidas, mientras ves que sus teléfonos están descolgados"

Comercio, distrito 5

En cuanto a los protagonistas del territorio, se observa que para todos el mayor impacto negativo se ha encontrado en la pérdida del contacto social, seguido de la falta de las actividades diarias. Sin embargo, si se atiende a la ciudadanía, además se pone el énfasis en el aumento del miedo y la angustia al contagio, mientras que, para las administraciones públicas y los recursos técnicos y profesionales, el acento recae en la brecha digital y en las dificultades que conlleva el uso de las tecnologías de la información y la comunicación.

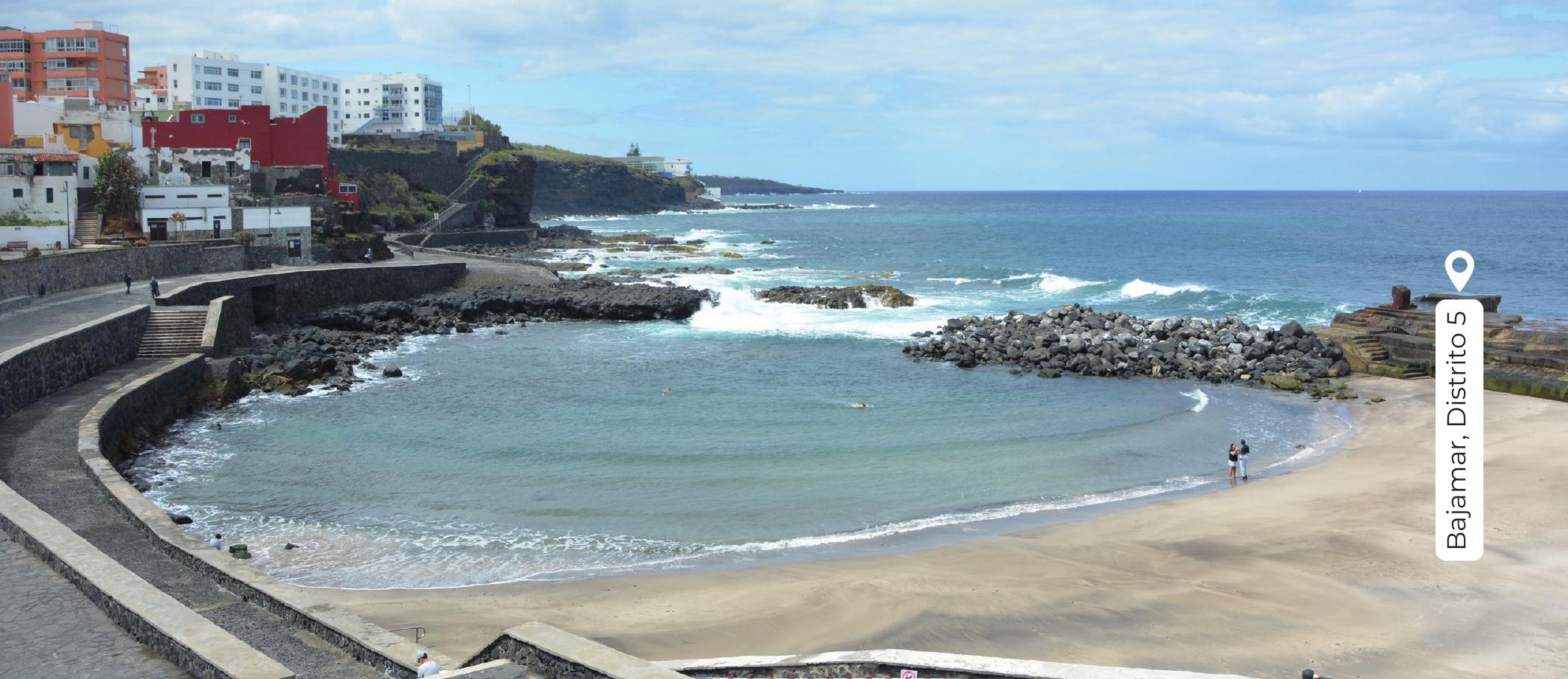




\section{Impactos negativos en la dimensión}

Economía identificados en el proceso de audición (\%)

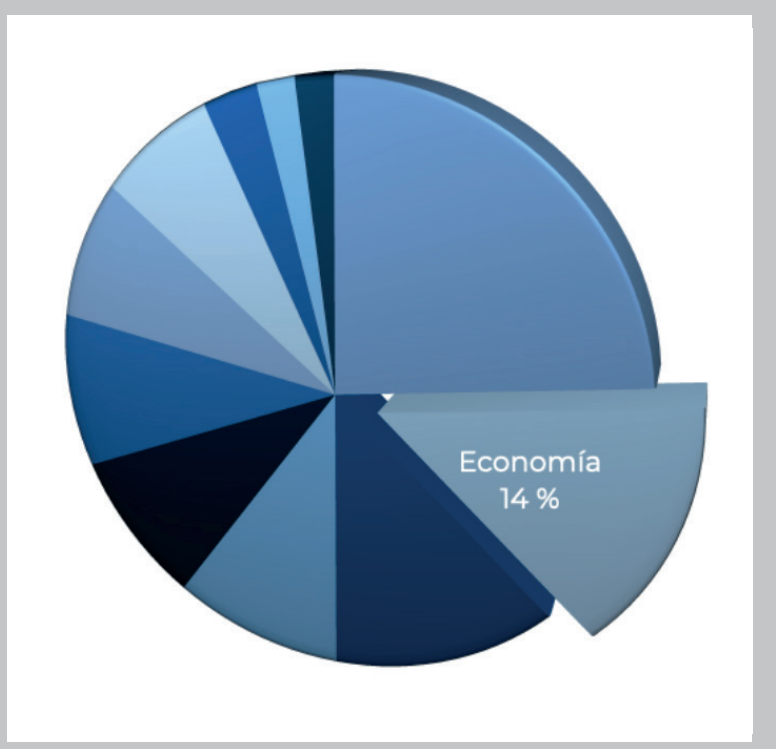

Fuente: Proceso de Audición del Proyecto Comunidad. Elaboración propia
"Lo económico se ha agravado con

la aparición de la COVID-79. Este año tenemos más alumnado de cuota cero que nunca, contando el centro con muy pocos ingresos de comedor"

\section{Centro Educativo de Infantil} y Primaria, distrito 3

Además del impacto en la situación económica de las familias del municipio, la pandemia también ha afectado a la red empresarial. Debido al periodo de confinamiento y a las medidas establecidas para evitar la propagación de la COVID-19, muchos negocios han tenido que cerrar sus puertas por la imposibilidad de asumir los gastos que conlleva tener abierto al público cuando las ventas han caído. Algunos negocios han podido permanecer abiertos, pero con muchas dificultades.

"Hemos notado que se ha empobrecido la zona. Han cerrado unos 25 comercios de la zona, siendo los mismos vecinos los dueños"

Asociación Vecinal, distrito 1

\section{Economía}

Una de cada dos personas identifica un impacto en la Economía. Al analizar los relatos, tras el proceso de audición, se observa que la incidencia del impacto económico se ha centrado en el ámbito familiar. Muchas familias han visto perder las fuentes de ingresos de una, varias o todas las personas que la componen, lo que ha derivado en un empeoramiento de su situación económica, llegando incluso a generarse situaciones de vulnerabilidad social y verse obligadas a recurrir a las ayudas sociales y a la solidaridad de la comunidad, dirigiéndose sobre todo a organizaciones no gubernamentales, a los Servicios Sociales municipales y a la propia vecindad.
Si nos centramos en los datos según protagonistas, la ciudadanía ha detectado mayor impacto negativo, en cuanto a economía, en el cierre de los negocios o en las dificultades por las que están pasando para mantenerlos abiertos; mientras que los recursos técnicos y profesionales han visto que el mayor impacto está en la precaria situación económica de las familias a raíz de la pandemia. 
Impactos negativos en la dimensión Salud identificados en el proceso de audición (\%)

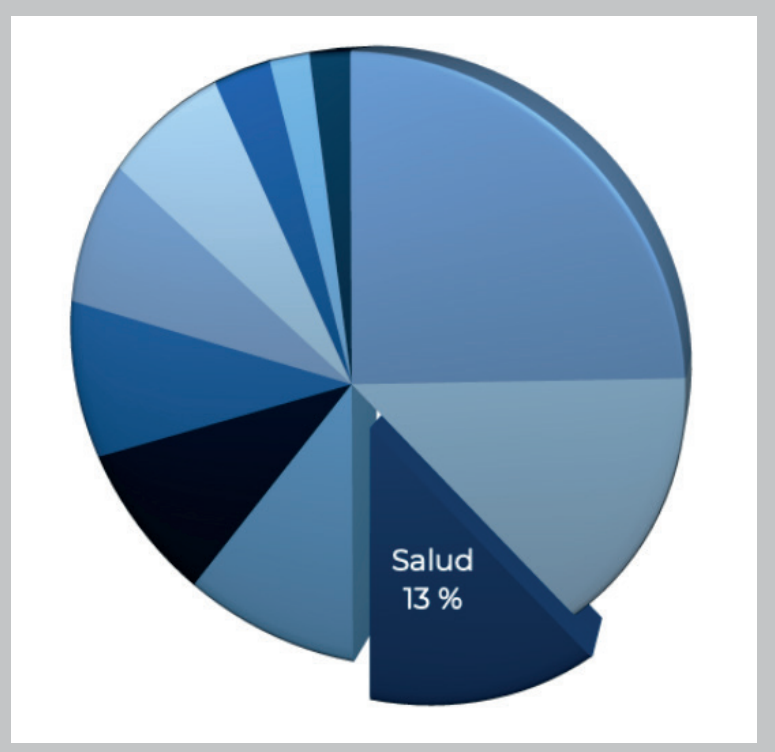

Fuente: Proceso de Audición del Proyecto Comunidad. Elaboración propia

\section{Salud}

Cuatro de cada diez personas reconocen un impacto negativo en relación con la Salud. Entre estos, el principal impacto que ha tenido la COVID-19 se relaciona con el deterioro del estado de ánimo y el incremento de síntomas asociados a la salud mental, en especial, circunstancias de estrés, ansiedad y depresión, derivadas de la situación social y también de la actitud y/o conductas de otras personas del entorno.
"Se han muerto algunos clientes, han cogido COVID-19 unos diez que sepamos y han muerto creo que dos. Los mayores lo han sufrido más, la gente tiene mucho

miedo. Todos los mayores que iban en guagua a Las Teresitas o de excursión lo están pasando mal al no poder realizar ya esa actividad física, tienen que moverse y caminar por su bien. Además, se han acelerado los problemas neurológicos como el alzhéimer. También noto que la gente está más nerviosa, con ataques de angustia, tomando ansiolíticos, etc."

Farmacia, distrito 1

La comunidad se manifiesta más triste de lo habitual, sin motivación por hacer actividades, presentando mayores situaciones de angustia y manifestando un aumento en el consumo de psicofármacos. En ocasiones, estas patologías también tienen repercusiones en aspectos físicos y se traducen en fatiga o cansancio. Desde otro plano, las personas que ya presentaban problemas asociados a la salud mental, han visto agravada su situación, en especial a consecuencia de la soledad que han experimentado durante el confinamiento obligado o el autoconfinamiento para prevenir el contagio.

Aunque en un menor grado, la COVID-19 también ha tenido dos impactos muy claros en el municipio. Por un lado, en relación con la atención sanitaria a la ciudadanía, que se ha visto resentida, sobre todo por la inseguridad que generó restringir la atención médica a la vía telefónica. No solo por las dificultades que implica para observar y diagnosticar a una persona, sino, también, por los inconvenientes para establecer el contacto telefónico, bien con el personal médico o con alguna persona que les pudiera atender. También en las dificultades organizativas del sistema de salud, como los centros de atención primaria o situaciones de desabastecimiento de algunos materiales, así como la desinformación que la situación generaba. 
"Pides una cita y tardan un montón. Ya todos sabemos lo que hay, hay que ir abriendo el abanico. Ahora todo es online, para los trámites te dan fechas muy largas, dos semanas o más. Las llamadas se cortan. No tienes manera de conectar con tu médico, te dan tres semanas para una cita telefónica"

Asociación Vecinal, distrito 1
"Sentimos enfado por las circunstancias en las que se encuentra el Centro de

Salud, porque no podemos ir para una consulta. Con esto del COVID-79 parece

que no hay nada más. Hay gente con ciertas patologías que las han tratado por teléfono cuando lo que quieren es que les atiendan en el Centro de Salud" Asociación Vecinal, distrito 5
Por otro lado, wsupuso una gran dificultad para muchas personas, no solo para quienes las padecían, como es el caso de personas con rutinas y seguimientos periódicos, sino, también, para el conjunto de profesionales que tenían a esas personas a cargo y que eran conscientes de la necesidad de sus atenciones.
El impacto fue similar en todos los distritos, sin embargo, desde la ciudadanía se ha puesto más el acento en las dificultades de la atención sanitaria, mientras que los recursos técnicos y profesionales destacan más las consecuencias psicológicas y las patologías que han surgido derivadas de la situación generada por la COVID-19.

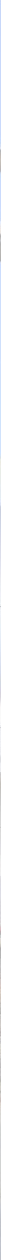


Impactos negativos en la dimensión

Educación identificados en el proceso de audición (\%)

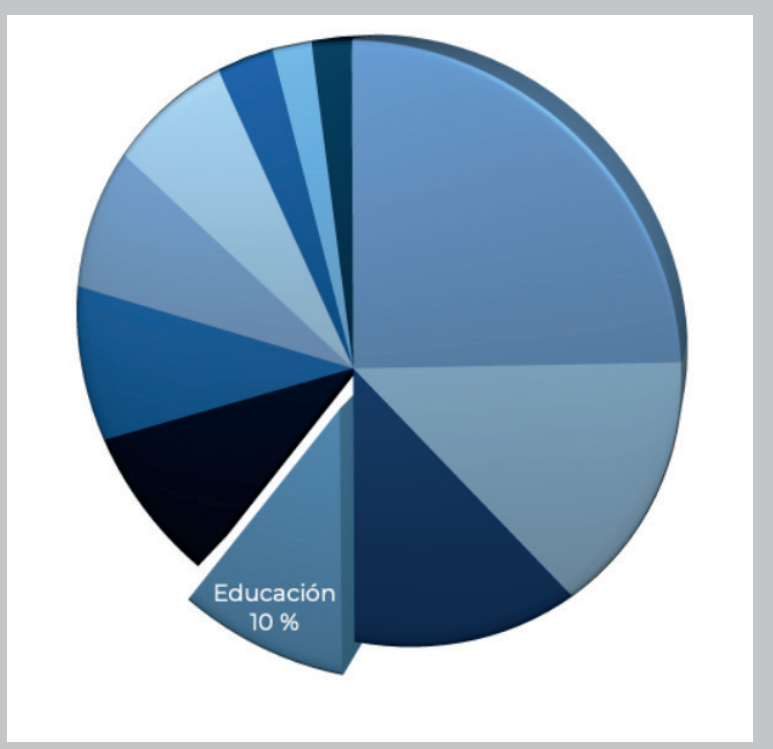

Fuente: Proceso de Audición del Proyecto Comunidad. Elaboración propia

\section{Educación}

Una de cada tres personas ha relatado un impacto negativo en Educación. Tras recopilar y analizar los relatos de la comunidad, destacan, como repercusión negativa principal, las dificultades experimentadas en el desarrollo habitual de la actividad docente en los centros educativos, como consecuencia de las medidas sanitarias, así como la cantidad de proyectos y acciones que han quedado en pausa con el comienzo de la pandemia.

\section{"No se pueden realizar actividades extraescolares, ni salidas, ni visitas como habitualmente lo hacíamos, porque no sabemos si podríamos mantener el protocolo fuera del centro"}

Centro Educativo de Infantil y Primaria, distrito 6
Por otro lado, se observa el impacto de la brecha digital, principalmente en el acceso a los recursos tecnológicos por parte de las familias, en especial, el contar con un ordenador, ya que muchas personas disponen de dispositivos telefónicos pero no de ordenadores. Y además, con una conexión a internet estable, la necesaria para poder hacer seguimiento de las actividades, puesto que, lo contrario, ha condicionado y dificultado el acceso a la educación del alumnado y su continuidad.

"Hay niños y niñas que no han podido acceder a las clases virtuales, siendo un hecho gravísimo. Básicamente se trata de incapacidad económica. La economía, en este sentido, delimita que haya acceso a productos digitales y, en última instancia, a la educación" Administración Local, distrito 1

Por último, se han puesto de relieve las dificultades para poder dar una respuesta ajustada a la insuficiencia de recursos humanos y materiales en los centros educativos. Ha aumentado la carga de trabajo de los equipos docentes y del resto de personas trabajadoras del centro, realizando importantes esfuerzos para ofrecer y garantizar que la educación llegara a los hogares del alumnado y contara con el apoyo familiar necesario, de manera especial en la enseñanza primaria, que pudiera complementar la labor del docente.

\section{"La carga laboral del profesorado es evidente que ha aumentado bastante. La carga de trabajo ha crecido inconmensurablemente" \\ Instituto de Enseñanza Secundaria, distrito 3}

En el distrito 3, la brecha digital y el deterioro en la comunicación entre centros educativos y familias ocupan el primer lugar como impactos negativos, dejando en un segundo plano las limitaciones cotidianas. Lo mismo ocurre en el distrito 1, donde las desventajas encontradas debido a la brecha digital, son más importantes que las dificultades en el día a día de la actividad educativa de los centros. 


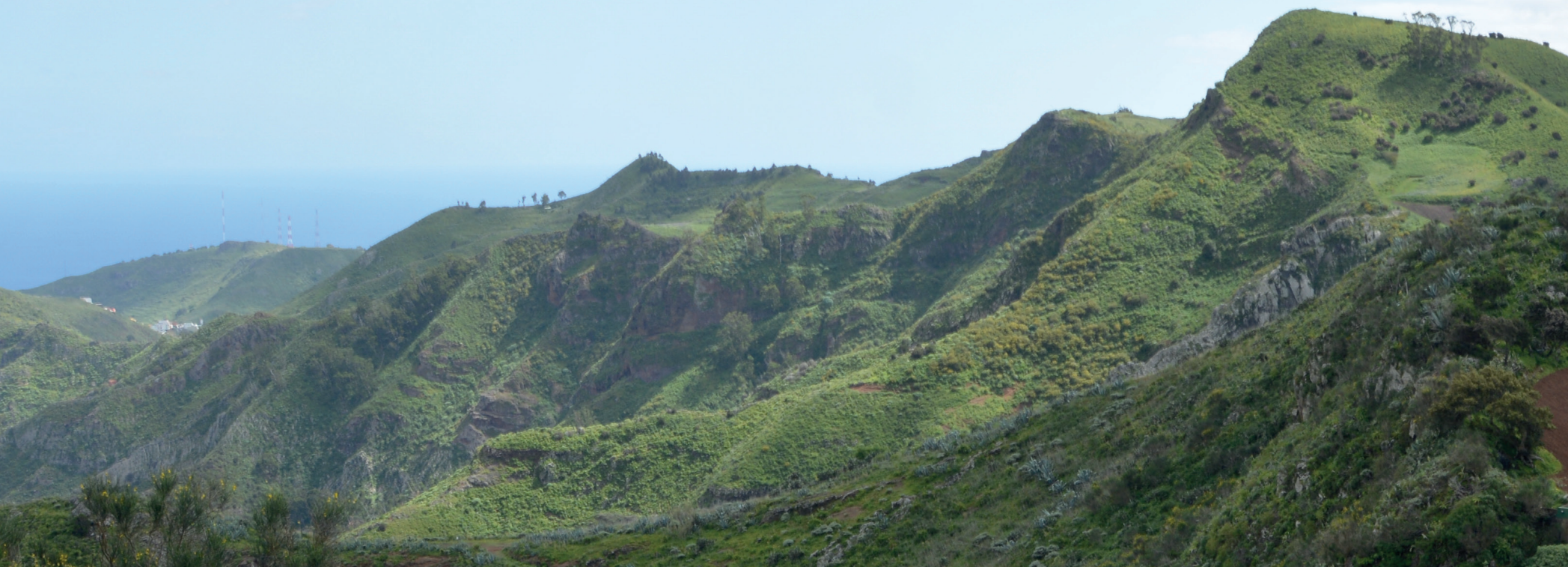

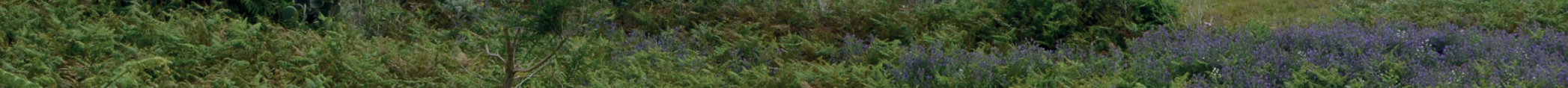

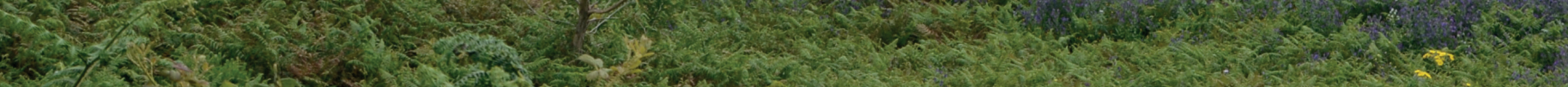

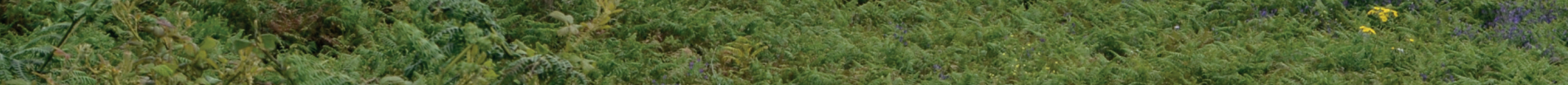
r.

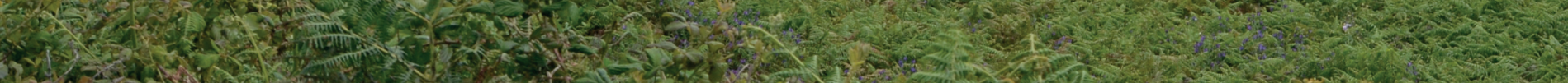
1.t. H.

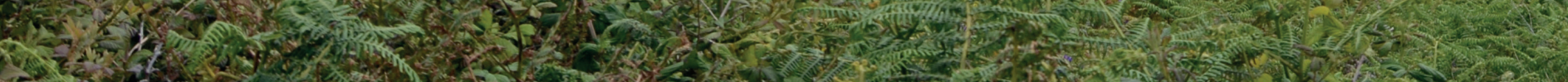

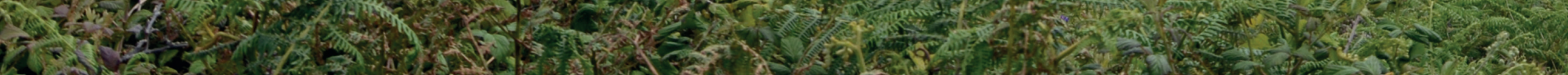

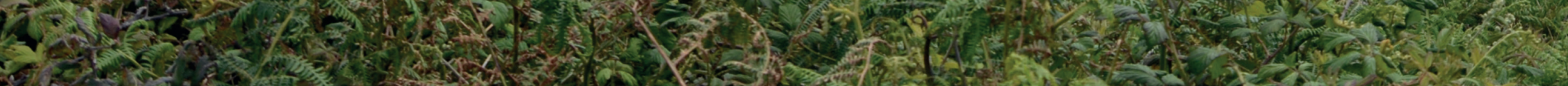

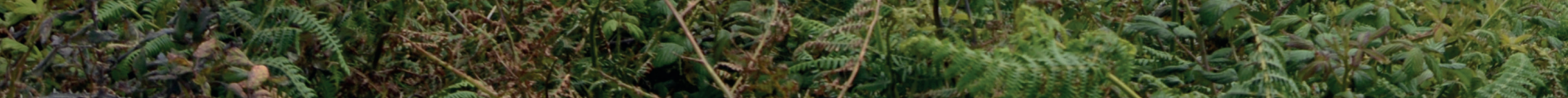

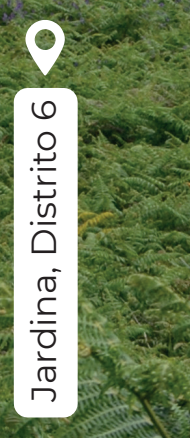
$3,1+2,15$ 
Impactos negativos en la dimensión Ocio identificados en el proceso de audición (\%)

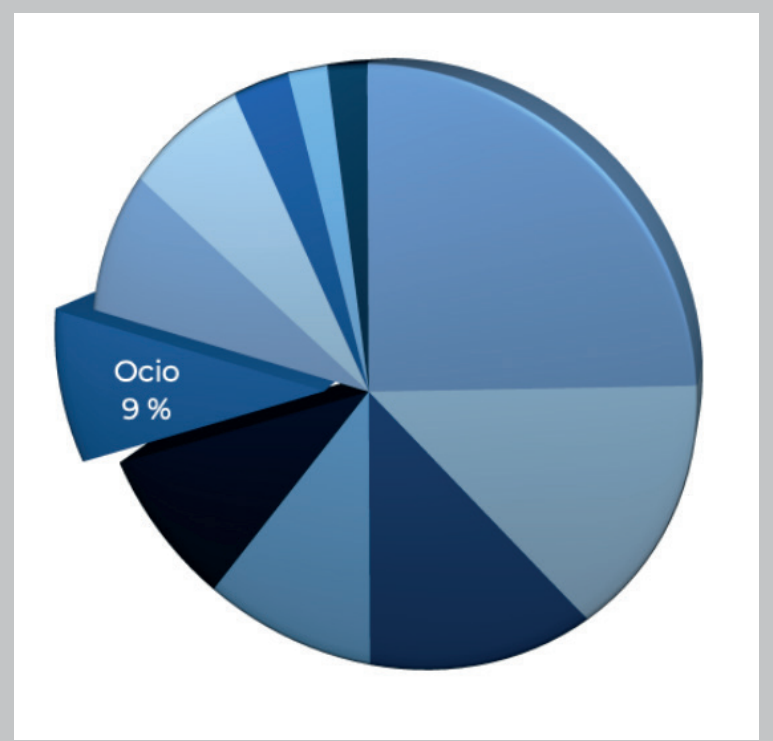

Fuente: Proceso de Audición del Proyecto Comunidad. Elaboración propia
"En la asociación, las acciones que hacemos son mayoritariamente grupales y con todo esto hemos tenido que cancelarlas casi todas"

Asociación cultural, distrito 2

\section{Ocio}

Una de cada tres personas ha compartido en su relato un impacto negativo en el ocio. En todos los casos, están vinculados con la implantación y el desarrollo de las medidas sanitarias establecidas por las autoridades competentes, que inciden en la confluencia de personas en un mismo espacio físico, desde el control de aforos hasta las limitaciones para reuniones grupales con personas no convivientes. Una gran parte de las actividades lúdicas han sido canceladas, o en algunos casos, han ajustado su participación según niveles de alerta sanitaria, haciéndolas menos accesibles a la población en general, sobre todo considerando que dichas actividades suelen ser grupales y desarrollarse en entornos cerrados.
El impacto negativo está muy diferenciado según el grupo de edad y/o colectivo al que se refiere, por ejemplo, las personas mayores en relación con el programa de talleres de ocio que se realizaban desde el Ayuntamiento de San Cristóbal de La Laguna y programas similares de otras administraciones públicas. $\bigcirc$ los grupos y colectivos con necesidades especiales, en relación con la oferta que habitualmente disfrutaban, entre otros. Los recursos técnicos y profesionales dan importancia al impacto que ha supuesto para las personas jóvenes del municipio y la carencia de una oferta específica. 
Impactos negativos en la dimensión

Servicios Sociales identificados en el proceso de audición (\%)

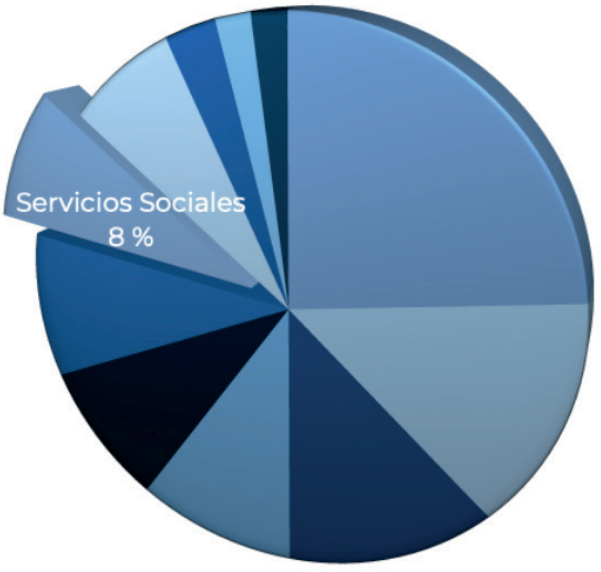

Fuente: Proceso de Audición del Proyecto Comunidad. Elaboración propia
"Sabemos que la gente está recurriendo a todo tipo de ayudas, la vida económica de la zona se paralizó"

Farmacia, distrito 5

\section{Servicios sociales}

Una de cada cuatro personas ha relatado un impacto negativo en los Servicios Sociales, uno de los principales pilares con que cuenta la administración local pública para poder hacer frente a las situaciones de vulnerabilidad, riesgo de exclusión y/o una manifiesta exclusión social de la ciudadanía. En este sentido, se observa un aumento del número de personas que han necesitado y/o han solicitado ayudas sociales, tanto a la administración, como a terceras entidades especializadas, parroquias y otros recursos, comparándolo con los momentos anteriores a la irrupción de la pandemia en el municipio.
Debido a que los ingresos económicos de muchas familias se han visto reducidos, han aumentado las solicitudes de ayudas, en su mayoría destinadas a la provisión de alimentación, aunque también destacan las ayudas de medicamentos, para la provisión de elementos básicos como son el abastecimiento de agua, el suministro de electricidad y de gas o, por último, el mantenimiento de los hogares, como ha sido el pago del alquiler. También aumentó el trámite de ayudas de Servicios Sociales, en especial y a consecuencia de medidas específicas que han surgido durante la pandemia, como ha sido el caso del Ingreso Mínimo Vital. 
Relación de impactos positivos según dimensiones identificadas en el proceso de audición (\%).

\section{Los impactos positivos}

La COVID-19 también ha traído consigo impactos que se consideran positivos, aunque a diferencia de los negativos, ni son tan numerosos ni están presentes en todas las dimensiones. Es importante señalar que la COVID-19 no genera el impacto positivo, sino la respuesta que la comunidad ofrece al reto que le supone.

Los impactos positivos están presentes en 68 de cada 100 relatos escuchados y se concentran en tres dimensiones bien definidas y concretas: Sociedad, Educación y Salud. Mientras que, el resto de dimensiones, están poco reflejadas, destacando por su presencia significativa en los relatos de las dimensiones de Ocio y Espacios públicos.

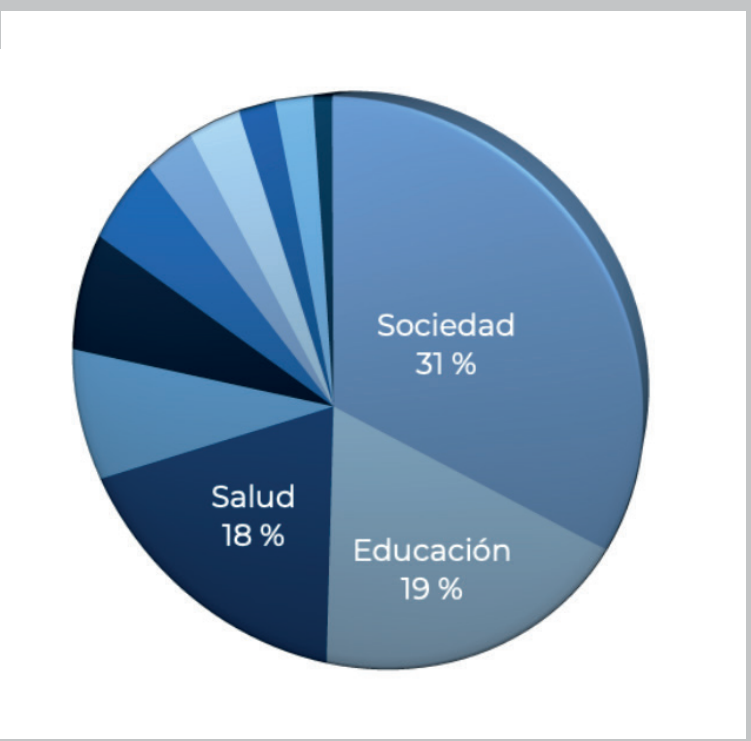

Fuente: Proceso de Audición del Proyecto Comunidad. Elaboración propia

Presencia en las escuchas realizadas de impactos positivos según dimensiones durante el proceso de audición (\%)

$100 \%$

$75 \%$

$50 \%$

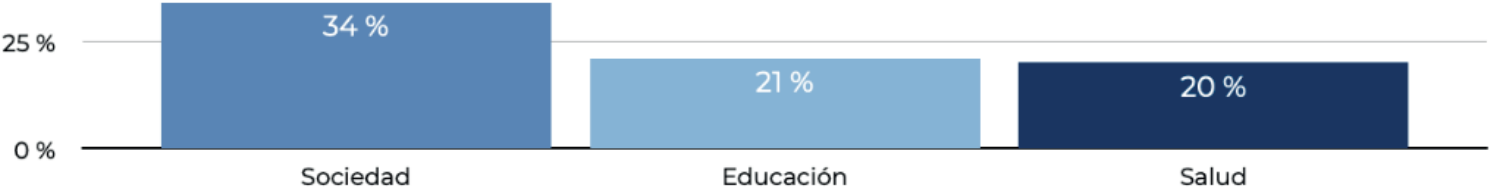

Fuente: Proceso de Audición del Proyecto Comunidad. Elaboración propia 
Impactos positivos en la dimensión Sociedad

identificados en el proceso de audición (\%)

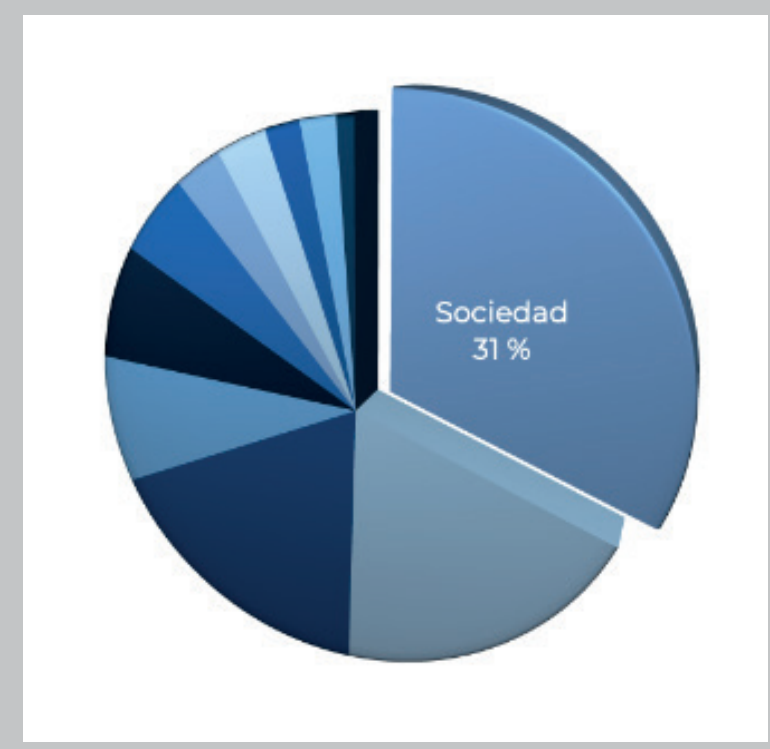

Fuente: Proceso de Audición del Proyecto Comunidad. Elaboración propia
"Se ha creado una familia en la zona. En las cafeterías del barrio se invitaba a desayunar y almorzar durante quince días a las personas sin recursos. Hubo solidaridad. La comunidad ha salido fortalecida y se ha acercado entre ella"

Asociación Vecinal, distrito 1

\section{Sociedad}

Una de cada tres personas relata un impacto positivo desde la dimensión de la sociedad. Este impacto está claramente definido en el aumento de las iniciativas solidarias en la ciudadanía y de las ayudas institucionales. Desde el inicio de la pandemia, las situaciones de dificultad que han sobrevenido a la comunidad, han generado y mantenido un sentimiento de solidaridad en la ciudadanía, en las empresas y en las entidades, todas estas entre sí, que era un hecho desconocido por muchas de las personas de la comunidad.

La situación vivida que ha agravado múltiples necesidades, ha propiciado la aparición de muchas iniciativas novedosas, desde bancos de alimentos organizados en los barrios a cuestiones más específicas como celebrar cumpleaños desde los balcones. La COVID19 ha sacado a relucir, en algunas ocasiones, la mejor cara de las personas. Igualmente se señala el apoyo de las instituciones, con diferentes ayudas y estrategias que paliaran las carencias surgidas con la crisis. 
Impactos positivos en la dimensión Salud identificados en el proceso de audición (\%)

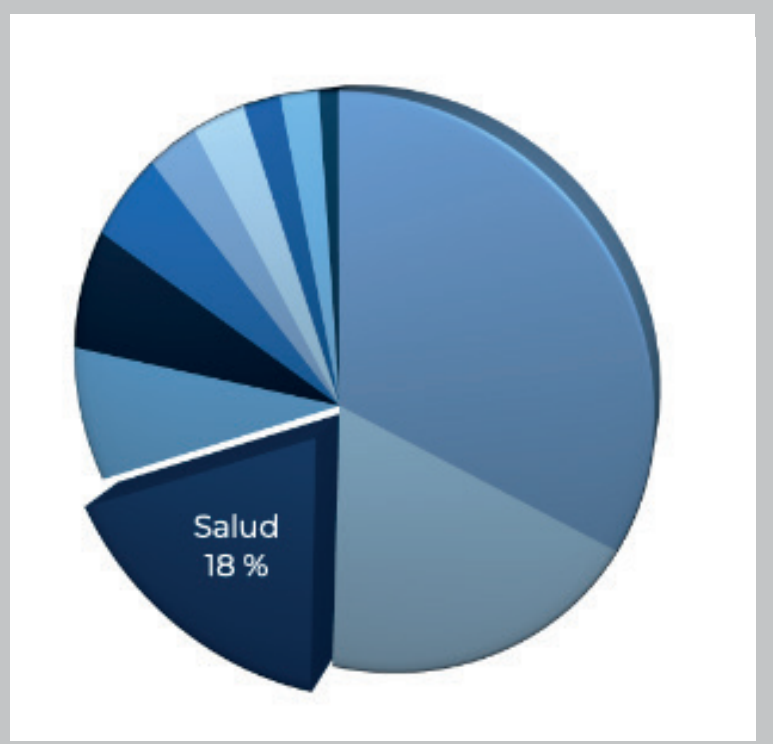

Fuente: Proceso de Audición del Proyecto Comunidad. Elaboración propia

\section{Salud}

Dos de cada diez personas han identificado un impacto positivo en la salud. Entre estos, se destaca una mejora en los hábitos de limpieza, tanto de los espacios comunes como de las personas, así como en la implementación de las medidas sanitarias y de protección individual, entendiéndose como un proceso de toma de conciencia y aprendizaje por parte de la población con respecto a la prevención de enfermedades y el mantenimiento de la salud personal y comunitaria.
"En cuanto a la salud comunitaria, creo que antes no se le daba importancia y actualmente, tras la cuarentena, ha quedado patente que te tienes que cuidar para cuidar a las demás personas"

Asociación juvenil, distrito 3

En menor medida, también se identifica como un impacto positivo la valoración que se hace de las nuevas tecnologías en el sistema sanitario que se han puesto en marcha a raíz de la pandemia, en especial, la posibilidad de digitalizar procedimientos y trámites por parte de los recursos técnicos sanitarios, como la expedición y gestión de recetas, y aunque con dificultades, la atención telemática.

"En esta pandemia reportamos avances no solo en técnicas de investigación biotecnológica, sino en las técnicas de relación con el paciente, como la telemedicina, que se consolidará como una herramienta de entrevista clínica muy importante. Esto es un cambio que considero positivo y que, de no haber sido por los condicionantes de esta pandemia, su implantación de forma natural habría sido más lenta y dificultosa"

Centro de Salud, distrito 1

Por último, y aunque en menor medida, se identifica un impacto positivo en la disminución de contagios con respecto a otras enfermedades, como la gripe o las enfermedades respiratorias, gracias a las medidas de distanciamiento y el uso de mascarillas a consecuencia de la COVID-19

"Lo positivo es que con la mascarilla han disminuido mucho las enfermedades del sistema respiratorio alto. Además, al comer más en casa y menos en los bares, han disminuido los problemas estomacales como la acidez" Farmacia, distrito 1 


\section{Impactos positivos en la dimensión}

Educación identificados en el proceso de audición (\%)

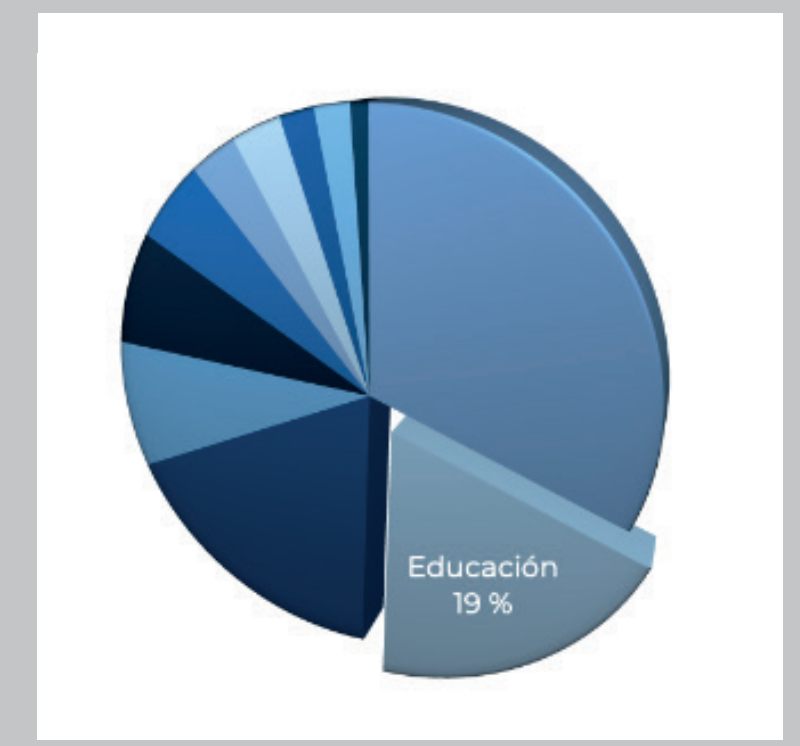

Fuente: Proceso de Audición del Proyecto Comunidad. Elaboración propia

\section{Educación}

Igual que en el apartado anterior, son dos de cada diez personas las que relatan un impacto positivo en la Educación. De una manera mayoritaria, se reconoce un aumento de la implicación familiar en los centros educativos y en las actividades que se desarrollan, con un notable refuerzo de los vínculos entre familias y equipo docente, que se manifiesta no solo en el desarrollo de la actividad docente, sino, también, en la organización de los centros con el compromiso activo por parte de las familias de cumplir con los protocolos y medidas sanitarias ante la COVID-19. Las personas coloquiadas valoran la buena labor de prevención en los centros y de concienciación escolar con respecto a los contagios, lo cual se manifiesta en índices bajos de alumnado infectado, protocolos y normas aceptados por familias y escolares, o el cambio en la actitud del alumnado, que se muestra respetuoso con la situación en los centros.
"La implicación de las familias en

el devenir del centro educativo ha aumentado ante la situación de la COVID19, ya que perciben mayor preocupación por el cumplimiento de las medidas, la entrega de las tareas escolares, etc."

Centro de Enseñanza Infantil y de Primaria, distrito 1

"La respuesta del colegio y la actuación de las familias es para aplaudir, no sólo por adaptarse a todo esto, sino por dar esa fluidez ante las nuevas medidas y tener esa concienciación"

Centro de Enseñanza Infantil y de Primaria, distrito 3

Además, también se recoge como un impacto positivo la iniciativa de formarse en las nuevas herramientas digitales, y así, poder ayudar a sus hijos e hijas en el nuevo contexto educativo que se ha generado tras la pandemia.

En relación con los impactos en la Educación, son los recursos técnicos y profesionales del ámbito educativo los que más han relatado impactos positivos. 


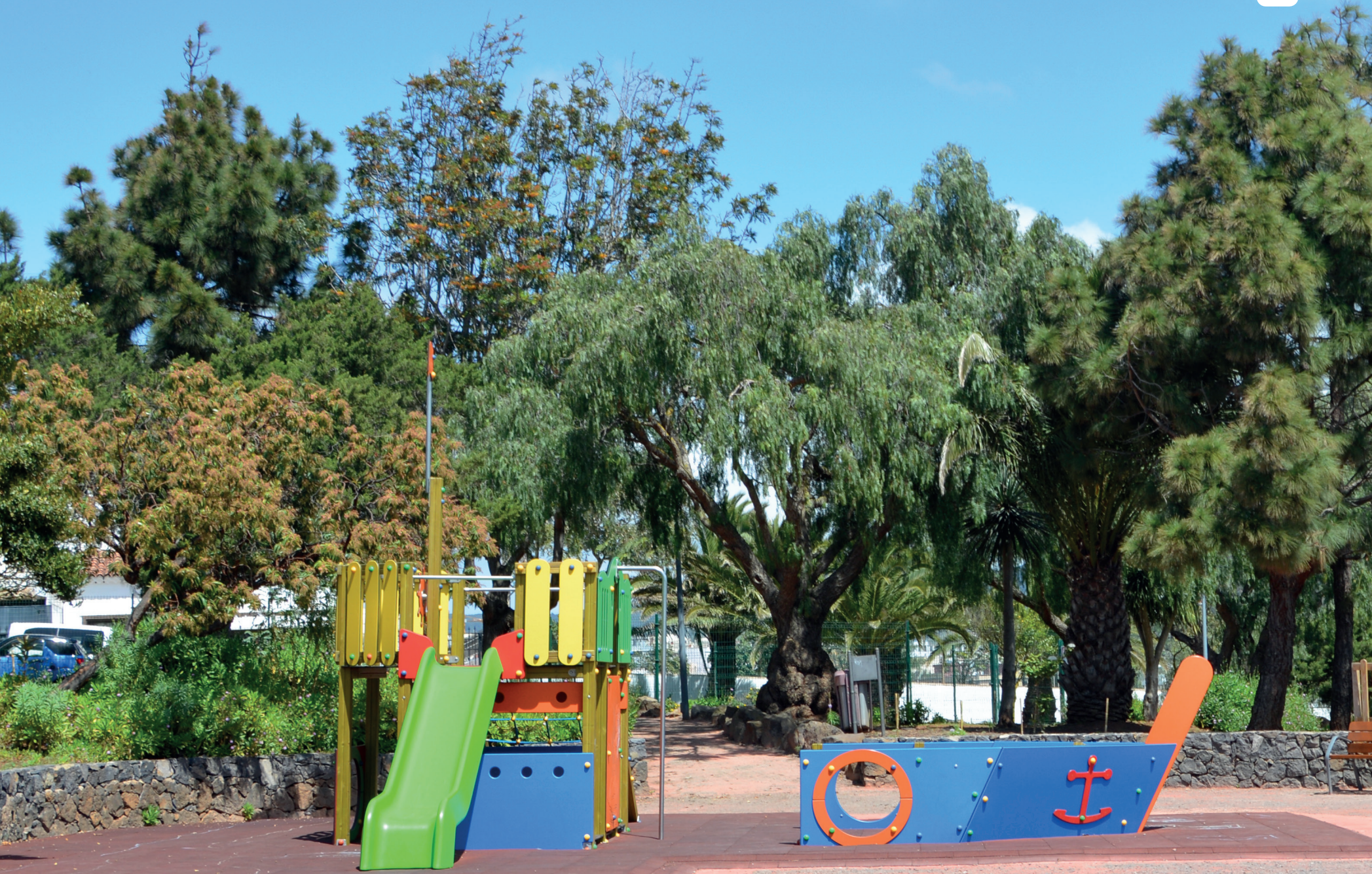




\section{Iniciativas desarrolladas}

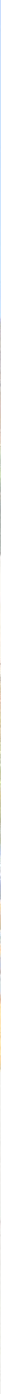


En los relatos obtenidos del Proceso de Audición se identificaron diferentes iniciativas para hacer frente a la COVID-19 que se desarrollaron durante el primer año de propagación del virus. En este apartado se hace un análisis de aquellas que han sido documentadas a través de la escucha a la comunidad, siendo posible que se hayan dado más iniciativas que no han sido contempladas aquí. El análisis incluye iniciativas impulsadas de manera original desde el municipio lagunero, entre los meses de febrero de 2020 y 2021, durante la aparición y desarrollo de la pandemia, no habiéndose producido si la COVID-19 no hubiera existido.

Las iniciativas se han clasificado según la tipología de las personas y entidades promotoras, según sea ciudadanía, recursos técnicos o las administraciones públicas las que las promuevan de manera genuina y en primera instancia, con independencia de que con posterioridad se hayan sumado otros protagonistas y resulten iniciativas en las que participan o implican a más de uno. En los siguientes apartados se hace un análisis, según este criterio de protagonistas promotores, de las iniciativas que se han identificado en el municipio. En el anexo II, se recoge el "Banco de Iniciativas Ciudadanas para hacer frente a la COVID-19", en el que se detalla con mayor profundidad y en concreto las iniciativas ciudadanas.

Aparte, y de forma general, se aprecian dos características comunes a las iniciativas que se desarrollaron en el municipio con independencia de sus personas y entidades promotoras.
1) Las iniciativas se focalizaron en mayor medida en la adaptación de protocolos y procedimientos de proyectos, programas y servicios ya existentes, antes que en la generación de nuevos.

2) Las iniciativas de carácter individual, de respuesta inmediata para resolver una necesidad básica, primaron sobre las iniciativas que implican un grado mayor de organización de grupos de personas o una estructura para su desarrollo que se mantuviera en el tiempo. 


\begin{abstract}
"Ahora mismo, la Asociación Vecinal se centra no tanto en las reivindicaciones de infraestructuras, como sí lo hace en la ayuda y cooperación entre la propia vecindad, en lo que tiene que ver con el reparto de alimentos y satisfacer primeras necesidades"
\end{abstract}

\section{Ciudadanía}

Las iniciativas ciudadanas pusieron de relieve un ejercicio de solidaridad entre vecinos y vecinas, entre estos y los comercios y empresas, entre éstas y las instituciones y administraciones públicas, que no era conocido por la comunidad lagunera. Se destaca que muchas de estas iniciativas fueron individuales, de personas puerta con puerta, de comercios con sus vecinos y vecinas habituales, entre otras fórmulas, siempre necesarias, pero de carácter espontáneo y terminaba una vez se solucionaba o atendía la situación que las había originado.

\section{"Dispusimos de un remanente económico en la asociación y decidimos invertir en las necesidades que Cáritas nos iba planteando, así como otras entidades o proyectos similares. Además, desde el sector de la agricultura también se han hecho donaciones de trajes y mascarillas que se usan en la agricultura al Centro de Salud de Tejina. También hemos donado hidrogel a los colegios, así como otro tipo de material de protección al Centro de Mayores. Creo que estas iniciativas colaborativas deberían mantenerse en el futuro"}

Asociación Cultural, distrito 5

Sin embargo, aunque menos, se desarrollaron iniciativas que tratando de lograr o conseguir similares objetivos, se alargaron en el tiempo e implicaron a muchas personas al mismo tiempo. Generaron, además, una organización que se mantiene hasta hoy en día en bastantes casos, y que, asimismo, requirieron un esfuerzo encomiable por parte de las personas y entidades que las promovieron. Iniciativas de distinta naturaleza y alcance, pero que permitieron disponer de muchas manos tendidas en momentos de extrema dificultad e incertidumbre.
Asociación Vecinal, distrito 4

Se han identificado 18 iniciativas ciudadanas y se pueden organizar en cinco categorías: (1) provisión y logística, (2) animación, (3) formación, (4) embellecimiento y (5) relaciones.

Las iniciativas ciudadanas de provisión y logística se centraron en servicios de distribución de productos alimenticios, medicamentos y otros bienes de subsistencia y/o materiales de prevención de contagios entre las diferentes personas y entidades. Las iniciativas de animación abarcaron desde la animación sociocultural, deportiva y comercial, orientada al entretenimiento, hasta la promoción de la salud y/o el fomento del consumo en el comercio local. Las iniciativas de formación comprendieron actividades de capacitación orientadas a la adquisición de competencias y destrezas, en especial, en el uso de la tecnología de la información y la comunicación. Las iniciativas de embellecimiento trataron de acondicionar y mejorar los espacios públicos o de uso común en el entorno de los barrios. Y por último, las iniciativas de relaciones tuvieron como objetivo el desarrollo de actividades de mejora de las relaciones y la convivencia entre las personas de una misma comunidad.

Cinco grupos de categorías que dieron una respuesta y cobertura solidaria a los diferentes retos que la COVID-19 planteó a la comunidad tras su aparición, que se sumaron a aquellas otras que eran impulsadas por los recursos técnicos y profesionales, por las propias administraciones públicas, pero, en este caso, surgidas de manera original desde la ciudadanía del municipio. 


\section{"Las personas con discapacidad se han visto muy aisladas, la Fundación \\ creó un grupo de voluntariado; éste se encargaba de llamarles, hacerles seguimiento y ayudarles con una escucha activa y amable en los días que duró el confinamiento"}

\section{Recursos técnicos}

Los recursos técnicos vinculados con el desarrollo de los servicios de carácter sanitarios, educativos, así como los conectados con la seguridad ciudadana, el empleo y los servicios sociales, tanto desde las entidades privadas como desde administraciones públicas, han experimentado cómo la COVID-19 ha afectado, de manera individual y colectiva, a las funciones y actividades que venían desarrollando antes de la situación de emergencia sanitaria. Desde el punto de vista general, se destacan los esfuerzos para habituarse a las nuevas medidas que han tenido que ser adoptadas, en especial, la digitalización de gran parte de los servicios que ofrecían, ya que la imposibilidad de relación directa o la no presencialidad ha hecho del contacto remoto una necesidad.

En este sentido y en su mayoría, se ha optado por plataformas digitales y medios telefónicos para llevar a cabo las actividades. Se ha visto reflejado, por ejemplo, en los Centros de Salud, que realizaron consultas por la vía telefónica, o en los Centros Educativos, que adaptaron sus clases presenciales a diferentes formas y medios telemáticos. A raíz de todo este proceso de telematización de medios y procedimientos, desde distintos centros y entidades, se han puesto en marcha actividades de formación en el uso de medios digitales y se han activado servicios de préstamo de dispositivos electrónicos.

Por otro lado, los recursos técnicos también relatan como iniciativa destacada la adaptación de los espacios, siguiendo las medidas de prevención de contagios indicadas por las autoridades sanitarias, como por ejemplo, ha sido la presencialidad adaptada, la creación de grupos burbuja, la adecuación de los espacios de trabajo, así como la señalización en diversas infraestructuras y establecimiento de medidas de prevención de contagios frente a la COVID-19.
Organización No Gubernamental, distrito 2

Otra consecuencia del impacto de la COVID-19 ha sido una diversificación de las funciones habituales, es decir, un proceso de adaptación con nuevas funciones o desarrollos, y en algunos casos, la reinvención total. Durante el confinamiento y la etapa posterior a éste, surgieron también nuevas iniciativas llevadas a cabo con el fin de ayudar a todas las personas que, por la situación de emergencia sanitaria, tuviesen dificultades o impedimentos, centrando las prioridades en atender y dar cobertura a necesidades básicas de la población. Y así, desde las entidades se crearon bancos de alimentos para los colectivos más vulnerables, se gestionaron bolsas de voluntariado, se recaudó dinero para las familias que lo necesitaban, se ofreció acogimiento para personas sin hogar, se proporcionó ayuda sanitaria cubriendo medicamentos $u$ ofreciendo mascarillas, entre otras actividades que, de manera normal, no desarrollaban o habitualmente eran realizadas por unas entidades en concreto. 
"La actividad "Plazas Vivas" ha ayudado un poco con el mantenimiento de las relaciones vecinales. También hemos disfrutado de la celebración del día de los finados acudiendo al teatro Leal a ver la obra Don Juan Tenorio y alguna otra actividad" Asociación de Mayores, distrito 4

\section{Administración}

Desde las administraciones públicas, las iniciativas se concentraron en la cobertura de necesidades básicas de la ciudadanía mediante ayudas económicas, en especial, con el propósito de responder rápido para cubrir todas las dificultades que se iban detectando en consonancia con las medidas adoptadas para evitar y prevenir contagios de la COVID-19. De manera relacionada, destaca el hecho de que también se destinaron muchos de los esfuerzos a ampliar los recursos ya existentes (albergues, tarjetas para la compra de alimentos, ayudas para el alquiler, entre otras similares), e incluso, a la gestión de los nuevos recursos que se generaron (Ingreso Canario de Emergencia) o servicios que se asumieron (dotación de mascarillas en los centros educativos).

"Creo que la mayor iniciativa en esta crisis fue el albergue para personas sin hogar durante el confinamiento"

\section{Organización No Gubernamental, distrito 3}

Desde la administración pública se han desarrollado otro tipo de iniciativas también, muy vinculadas con las obligaciones que conlleva su naturaleza y que han sido novedosas. Entre ellas, destaca la información y comunicación de medidas y normas ajustadas a la situación existente, o de manera más novedosa, información para la prevención y la promoción de la salud. Igual, se sucedieron iniciativas a raíz del periodo de confinamiento obligatorio, que se orientaron a mantener el contacto con la ciudadanía, en especial, con los colectivos más vulnerables y las personas mayores. $Y$ en virtud de que las medidas lo fueron permitiendo, también con la generación de alternativas de ocio y entretenimiento seguro, es decir, actividades en las que se garantizara la adopción de medidas y provisión de medios necesarios para la prevención de contagios.
Por último, al igual que con las iniciativas promovidas por los recursos técnicos, se orientaron recursos hacia la dotación de medios y dispositivos tecnológicos que permitieran superar la brecha digital, en especial, destinados a la educación del alumnado con dificultades en estas cuestiones. 


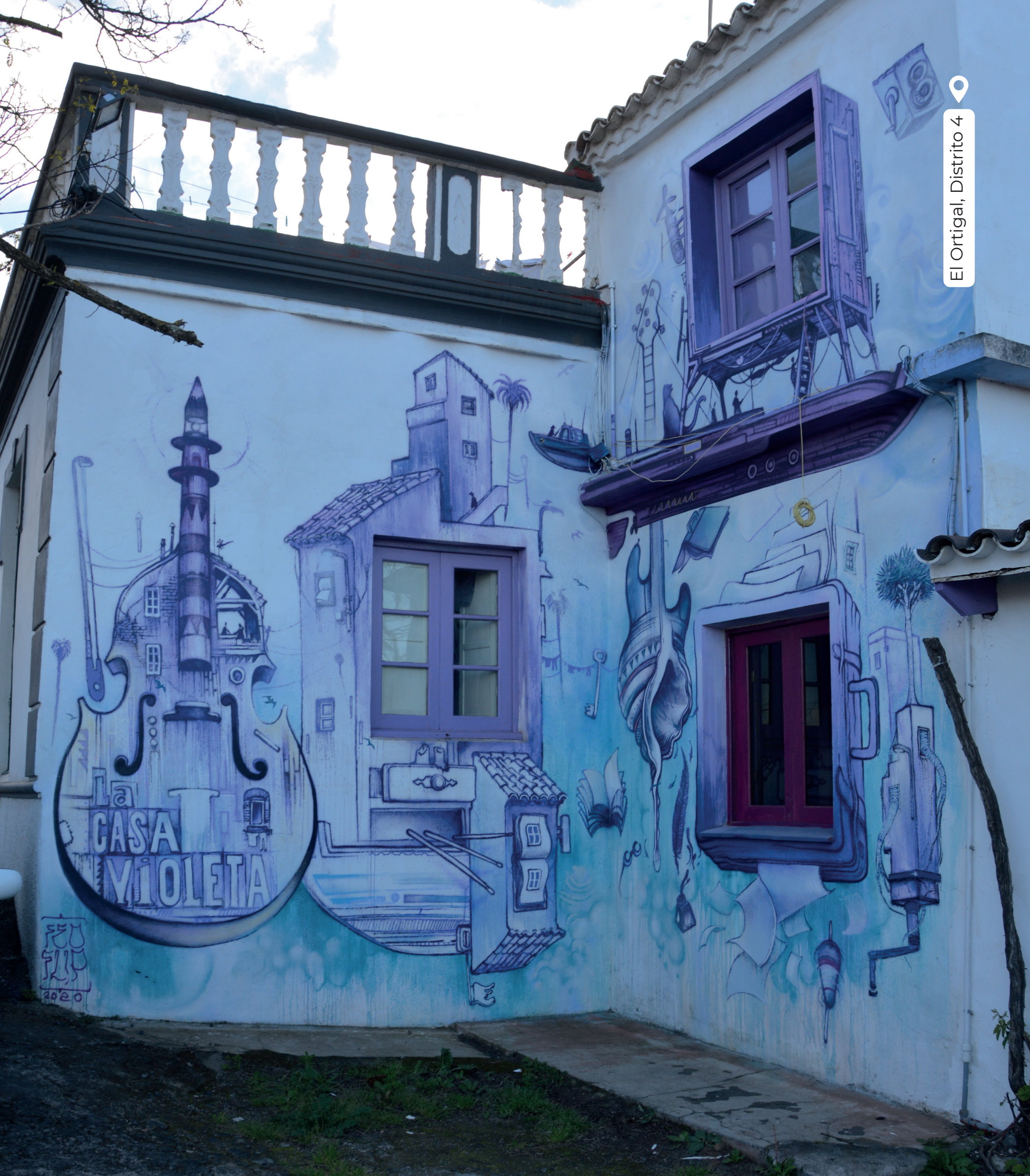


Las expectativas remiten a las percepciones que la comunidad tiene sobre su futuro en el municipio de San Cristóbal de La Laguna. Una expectativa no tiene por qué ser una situación o cuestión que termine sucediendo, pero en el momento presente, en el que se escucha a la persona, le hace pensar que sucederá. Las expectativas permiten concretar el grado de pesimismo u optimismo que la comunidad manifiesta en relación con el futuro que se vivirá; ponen el acento en las dimensiones que les preocupan o interesan.

Al igual que sucede con los impactos, las expectativas pueden ser negativas o positivas. De manera genérica, 41 personas de cada 100 compartió alguna expectativa sobre el futuro. $Y$, a diferencia de los impactos, las expectativas positivas, aunque por poco, superan a las negativas. Las expectativas, al igual que los impactos, recorren las diferentes dimensiones que se han propuesto en el análisis para tratar de comprender, de una manera amplia, el ámbito social en el que se desarrolla la comunidad y los sectores desde o sobre los que se organiza su acción. Tampoco todas las dimensiones están reflejadas en cada apartado, como se viene haciendo en los epígrafes anteriores, solo se contemplan las agregaciones mayores con el objetivo de identificar los relatos preferentes de la comunidad. En este sentido, en el apartado de expectativas, se han recogido aquellos aspectos que han estado presentes, como mínimo, en el 5\% de todas las escuchas realizadas.
Relación entre impactos negativos y positivos identificados en el proceso de audición (\%)
Presencia en las escuchas realizadas de impactos negativos y positivos durante el proceso de audición (\%).

$100 \%$

$75 \%$

$50 \%$

$25 \%$

$0 \%$

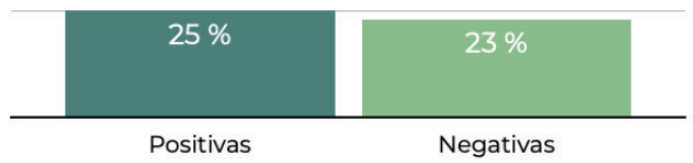




\section{Expectativas positivas}

Una de cada cuatro personas relata una expectativa en positivo en el municipio, aunque solo de manera significativa sobre dos ámbitos: la Sociedad y la Salud. En un análisis de detalle, todas las dimensiones que conllevan una mejora inmediata y plausible asociada a una relajación de las medidas o la desaparición de las mismas, sobre todo, en lo que respecta al uso y desplazamientos a los diferentes espacios a voluntad, así como las aglomeraciones y confluencia de personas en los mismos, tienen una tendencia positiva en relación con las expectativas. Ejemplo de esto, son los ámbitos del Ocio, el Deporte, la Cultura, y como es obvio, los Espacios públicos.

Relación de expectativas positivas según dimensiones identificadas en el proceso de audición (\%). (\%)

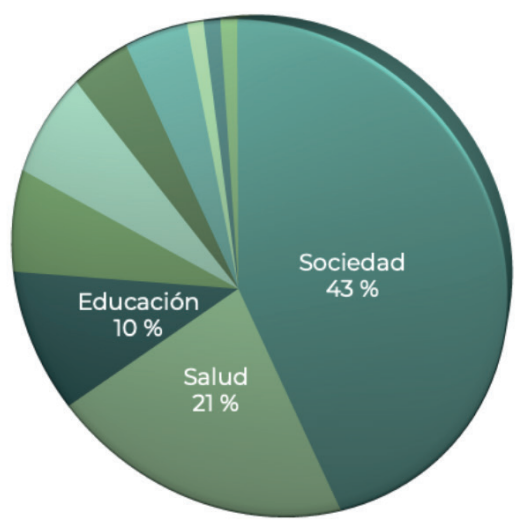

Presencia en las escuchas realizadas de expectativas positivas según dimensiones durante el proceso de audición (\%).

$100 \%$

$75 \%$

$50 \%$

$25 \%$

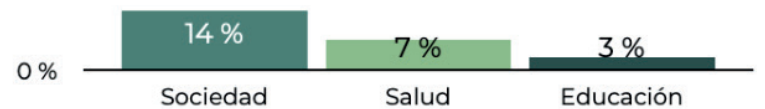


"Hay cuestiones que se van a quedar, será una nueva manera de vivir, de afrontar los problemas y de relacionarnos"

Administración Local, distrito 1
"En el futuro de la COVID-79, la población tiene expectativas de que se venza la pandemia y hay confianza en que la situación mejore. No solo por avances en la vacuna, sino de que aparezcan nuevos fármacos que ayuden a controlar la enfermedad o que las consecuencias no sean graves, asimilándose en un futuro a ser como una especie de gripe estacional, de modo que las expectativas futuras de la COVID-19 podrían ser que, sin desaparecer, no tenga consecuencias de crisis sanitaria ni social y pase por modular la enfermedad para que sean epidemias localizadas y en cortos periodos de tiempo"

Centro de Salud, distrito 1

\section{Sociedad}

Una de cada siete personas piensa que tras la situación de pandemia vivida en el municipio hay margen para que la sociedad mejore, en concreto y de manera mayoritaria, por la percepción de que se están sucediendo múltiples cambios en los estilos de vida que, sumado al proceso de adaptación a la nueva normalidad, provocará un día a día totalmente nuevo pero no por ello negativo. Incluso, en algunos relatos, se afirma que estos cambios han sido positivos y que han ayudado a la sociedad a avanzar, a ser más consciente de sus limitaciones, interpelando a las personas a implicarse en su mejora.

Cabe destacar la visión concreta en este ámbito de la ciudadanía, la cual mantiene esa expectativa positiva de los cambios que ocurrirán en la vida cotidiana, aunque manifiesta también su deseo de retomar, desde que se pueda, las actividades que de manera habitual se hacían. Unido a esto, las personas se muestran confiadas por la llegada de la vacuna y las posibilidades que ofrece para recuperar el ritmo de la sociedad con mayor facilidad.

\section{Salud}

Una de cada catorce personas relata una expectativa positiva para la comunidad en el ámbito de la Salud, muy en relación con los efectos saludables de la vacunación en la población, así como en su vínculo con los avances médicos que se han podido generar tras el reto para la salud a escala internacional derivado de la aparición del virus SARS-CoV-2. 


\section{Expectativas negativas}

Poco más de una persona de cada cinco comparte una expectativa negativa que podría afectar al municipio y a su comunidad. Igual que con las expectativas positivas, hay una concentración en dos ámbitos específicos: la Economía y la Sociedad. El análisis en detalle, permite observar que, en aquellas dimensiones en las que no hay una mejora inmediata y directa, derivada de una vuelta a la normalidad sin medidas sanitarias de prevención de contagio, las expectativas son negativas. En esta ocasión se hace referencia a la Economía y al Empleo. Además, influye en Servicios Sociales por su relación indirecta con las situaciones de precariedad y vulnerabilidad social que generarían la persistencia de una situación negativa en el empleo y en la economía.
"A nivel emocional también ha afectado en el barrio y creo que nos afectará para siempre, porque las distancias se mantendrán, pues se nos quedará grabado o al menos tardaremos mucho en volver a la normalidad anterior a la COVID-19. Ojalá que no sea así".

Asociación Vecinal, distrito 6

\section{Sociedad}

Una de cada diez personas ha relatado una expectativa negativa vinculada con la sociedad que podría darse en un futuro. Esta expectativa negativa se centra en el impacto que podría tener la forma en la que las personas se relacionen en los próximos años y que esto ocasione implicaciones emocionales, afectivas y psicológicas perjudiciales. Sobre todo, en cuanto a las personas más jóvenes y a las mayores preocupa que se normalice esa pérdida de contacto social que se ha vivido y que esto condicione el carácter de las personas jóvenes y/o genere secuelas en las personas mayores. También se reitera la idea de que, con el paso del tiempo, la comunidad podría perder cada vez más el interés por lo asociativo, así como la motivación a la hora de participar en actividades comunitarias.
Relación de expectativas positivas según dimensiones identificadas en el proceso de audición (\%). (\%)
Presencia en las escuchas realizadas de expectativas positivas según dimensiones durante el proceso de audición (\%).

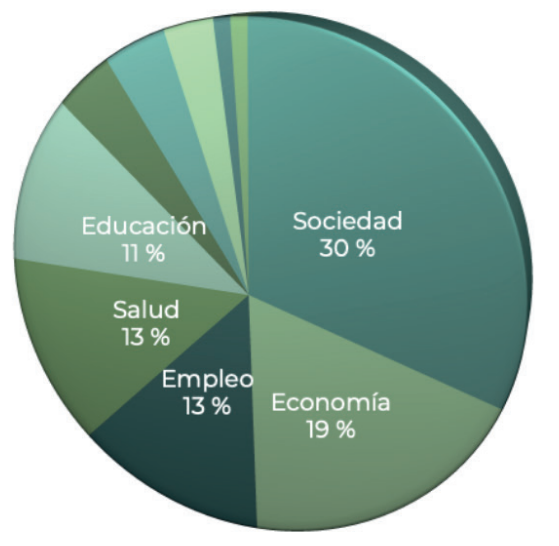

$100 \%$

$75 \%$

$50 \%$

$25 \%$

$10 \%$

$0 \%$

Sociedad Economía Empleo Salud Educación

Fuente: Proceso de Audición del Proyecto Comunidad. Elaboración propia 
"Es muy preocupante que a día de hoy se negocien los ERTES hasta, por ejemplo, el mes de mayo; porque no se sabe cuándo va a acabarse esto"

Asociación empresarial, distrito 3

\section{Economía}

Dos de cada treinta personas han manifestado su preocupación por algunas expectativas negativas que pueden darse en la Economía, a raíz de la situación vivida y de que ésta se mantenga en el tiempo. La primera y más reiterada es la dificultad de que las empresas puedan seguir haciendo frente a todos los gastos que están teniendo, acentuado por la pérdida de ingresos, y por tanto, que esto derive en su cierre. De igual modo, esta expectativa negativa no se limita al ámbito de las sociedades mercantiles, también se incluye a las personas autónomas del municipio.

\section{"Las PYMES están tratando de mantener sus negocios abiertos, pero ya las cargas y deudas no se lo permiten"}

Entidad religiosa, distrito 3

Aparte y en consecuencia, la expectativa que se manifiesta es que aumente la cantidad de personas en situación de ERTE, en el mejor de los casos, o en el peor de ellos, que se incremente el desempleo. Fruto de ambas situaciones, habría un impacto directo en las posibilidades de las familias y el consumo, dificultando más si cabe el mantenimiento de la economía local.
Estas expectativas negativas se han presentado por igual en los distritos 1 y 3 del municipio. Sin embargo, en el resto de distritos (2, 4, 5 y 6) no se han identificado expectativas negativas de Economía entre las personas participantes en el proceso de audición.

Por último, las expectativas negativas se han percibido por parte de los tres protagonistas del territorio: ciudadanía, recursos técnicos y profesionales y administración. Siendo en el caso de la ciudadanía referidos, en su mayoría, al cierre de las empresas, a la situación de los ERTES y a la imposibilidad de seguir manteniendo los modelos económicos actuales. En el caso de los recursos técnicos y profesionales, aluden a la aproximación de una crisis económica fuerte y a la incertidumbre y preocupación por la situación económica futura; igual que en el caso de la Administración, en el que además se añade la imposibilidad de seguir manteniendo los modelos económicos actuales. 


\section{Aprendizajes y conflictos}

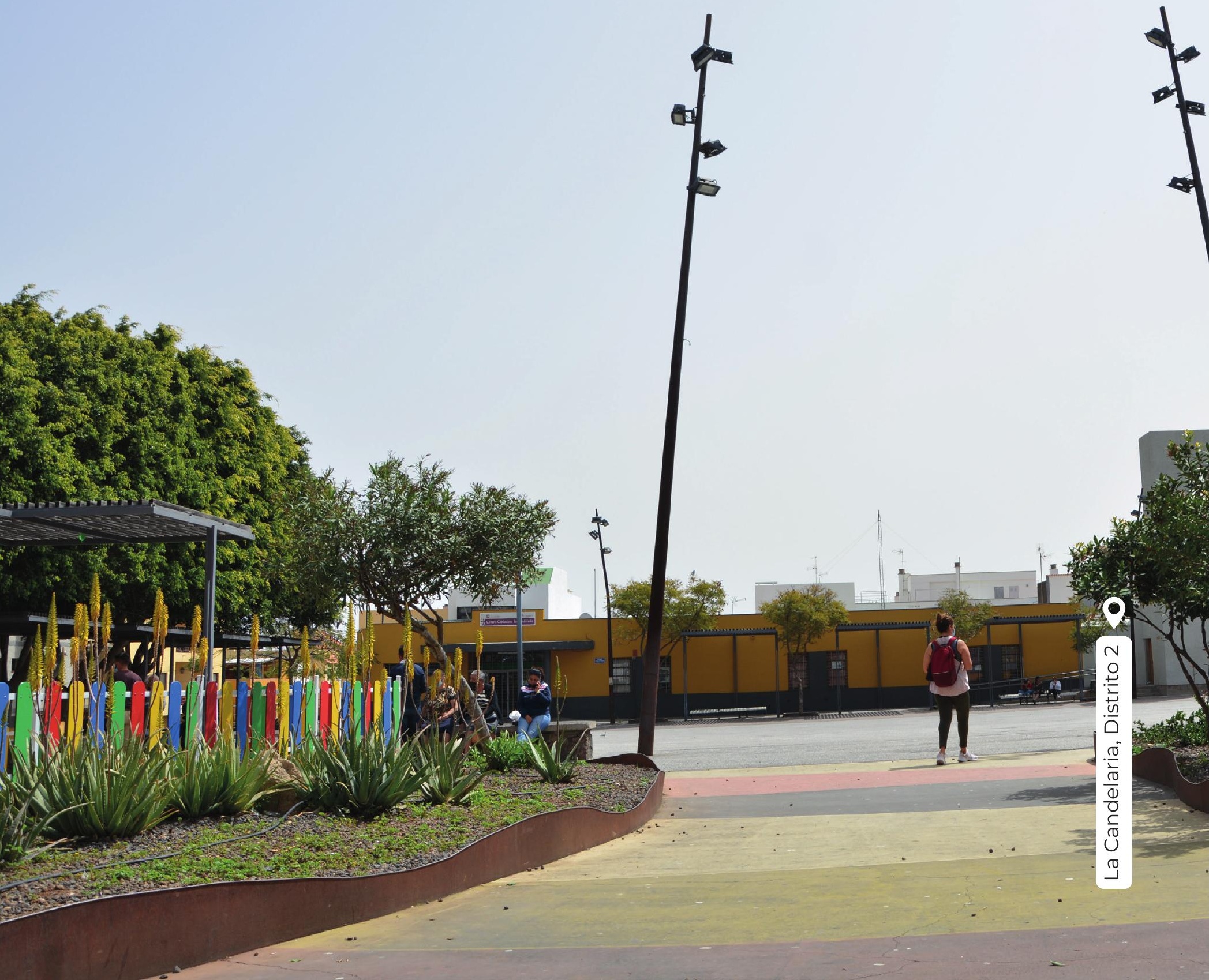


Un año desde la irrupción de la pandemia en el municipio deja tras de sí para la comunidad, entre otros aspectos, los impactos que se han vivido y las iniciativas que se han desarrollado. Impactos que han afectado o iniciativas que se han puesto en marcha por el conjunto de la comunidad, desde las personas más jóvenes hasta las de edad más avanzada, desde personas que han vivido otras crisis de salud pública, hasta aquellas para las que la irrupción de la COVID-19 ha sido su primera crisis sanitaria. Muchas experiencias vividas por la comunidad desde diferentes puntos de vista, que atesoran un valor importante si se es capaz de analizarlas.

En este apartado se propone identificar cuáles han sido los principales conflictos que se han producido desde la dimensión comunitaria. Entendiendo el conflicto como una situación real, vivida, bien definida, que implica a dos o más partes, en la que la persona que ha sido escuchada es una. Es importante compartir la idea de que un conflicto no es un problema en sí mismo, ni siquiera tiene por qué ser un impacto negativo. Un conflicto es algo que se ha solucionado o está pendiente de solucionar. Igual, y relacionado con los conflictos, se encuentran los aprendizajes. Un aprendizaje es algo que queda en la comunidad, algo que ha cambiado la forma de hacer o comprender una cuestión concreta, de normal, tras haber gestionado y resuelto un conflicto existente.

El análisis del binomio conflicto-aprendizaje complementa el análisis impacto-expectativa realizado en apartados anteriores. Pone el foco de atención sobre lo que queda en el presente para la comunidad, acerca de lo que se ha resuelto (aprendizaje) y lo que está pendiente de resolverse (conflicto).
Relación entre conflictos y aprendizajes identificados en el proceso de audición (\%)
Presencia en las escuchas realizadas de conflictos y aprendizajes durante el proceso de audición (\%).

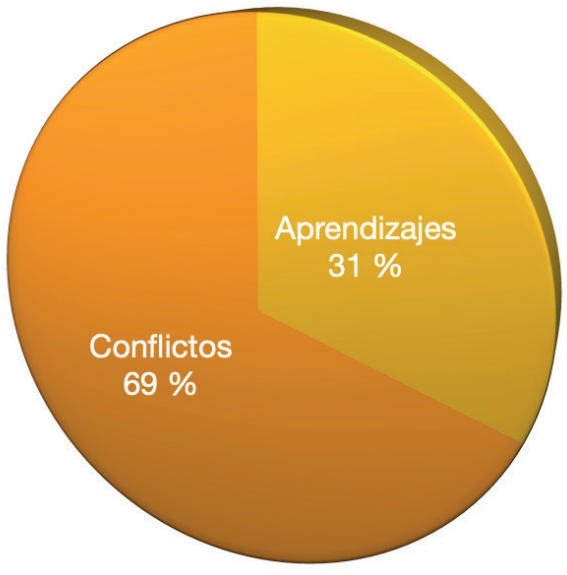

$100 \%$

$75 \%$

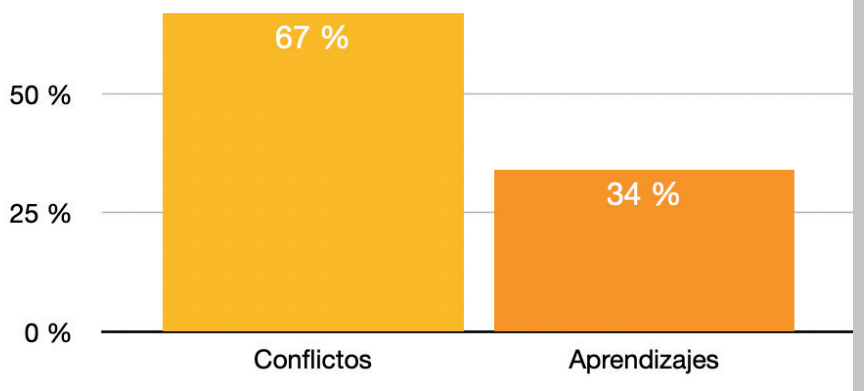

Fuente: Proceso de Audición del Proyecto Comunidad. Elaboración propia 
De hecho, para facilitar el análisis se propone hacer tres categorías, atendiendo a la capacidad que tienen o han tenido las personas que conforman la comunidad para resolver conflictos. Por un lado, está la categoría personal, que se refiere a un primer nivel, al de la persona y su entorno familiar más cercano, donde las personas tienen mayor capacidad para resolver conflictos. En un segundo nivel, se encuentra la categoría profesional, que se refiere al entorno laboral de la persona, donde ésta participa en un colectivo concreto pero dónde su capacidad de gestionar conflictos debe ser colegiada. Y, por último, la categoría social, un tercer nivel que hace referencia al entorno social en el que la persona se desenvuelve o del que se siente parte, en el que la capacidad de resolver conflictos existe, pero es menor; requiere de la implicación de un mayor número de personas de la comunidad.

Atendiendo a estas cuestiones, la comunidad de San Cristóbal de La Laguna relata un mayor número de conflictos activos que de aprendizajes realizados. Esta situación refleja que, en el momento en el que se ha realizado el Proceso de Audición, quedan conflictos por resolver. Y en consecuencia, aprendizajes que obtener de la irrupción de la pandemia y de la gestión que ha hecho la comunidad de la misma.

Otro aspecto relevante es que es la categoría social, la que se encuentra más alejada de la capacidad de gestión individual de las personas, es la que concentra el mayor número de conflictos. Un espacio que ha carecido de unidad y en el que se han concentrado la mayoría de las tensiones no resueltas de la comunidad.

En el caso de los aprendizajes, la mayoría, se ubican en la categoría profesional, un ámbito que, como se pudo observar en los impactos positivos y en las iniciativas que se desarrollaron, contaba con muchos aspectos favorables, a diferencia de otros, que se han consolidado durante el año de pandemia 


\section{Conflictos}

Los conflictos han primado sobre los aprendizajes. De cada 100 personas de la comunidad que han sido escuchadas, 66 han identificado conflictos que están activos, que persisten y que están pendientes de resolver. Como se mencionaba con anterioridad, los conflictos no tienen por qué ser negativos, pero sí se hace necesaria su gestión para que no terminen siéndolo. La convivencia se construye a partir de una intensificación de las relaciones entre las partes de una comunidad y estas relaciones no están exentas de conflictos. Gestionarlos y resolverlos de manera pacífica, lo que requiere de por sí que existan conflictos, es clave para poder tener una comunidad cohesionada en la que prime la convivencia.

A diferencia de los impactos-expectativas, en los conflictos-aprendizajes se analizarán las mismas dimensiones (personal, profesional y social). Aunque no todas tienen el mismo peso en los relatos escuchados. El conflicto social está presente en el 49\% de las escuchas realizadas, el profesional en el $34 \%$ y, solo con el $10 \%$, se encuentra el conflicto personal.

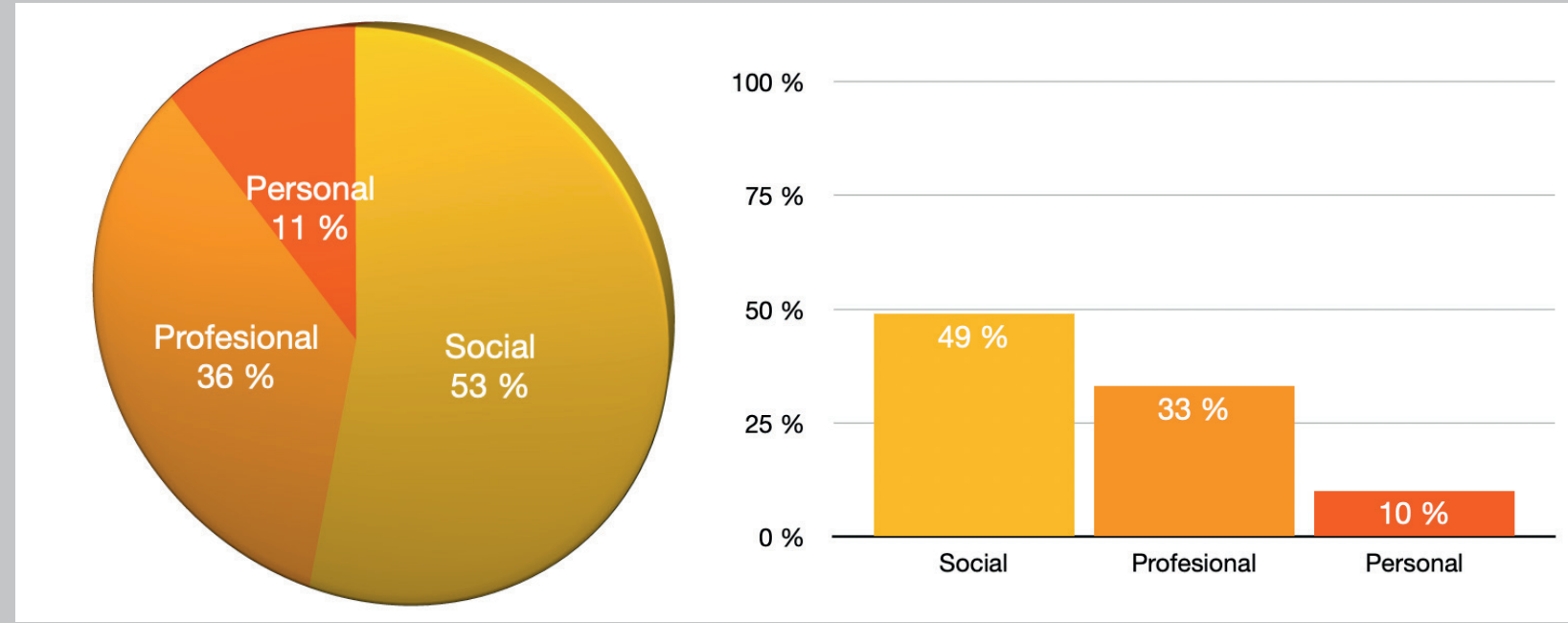

Fuente: Proceso de Audición del Proyecto Comunidad. Elaboración propia 
"La información dada a la ciudadanía debe ser clara y precisa. Pensamos que ha faltado información contrastada sobre el virus por parte de los expertos y al mismo tiempo ha habido una sobreinformación a través de los medios de comunicación que

ha generado una gran confusión"

\section{Conflicto social}

Una de cada dos personas expresa que está siendo parte de un conflicto social. La mayor preocupación a nivel social de las personas que han participado en el Proceso de Audición se centra en el incumplimiento de las medidas sanitarias adoptadas para evitar la propagación de la COVID-19, destacando aspectos como la no utilización de la mascarilla, el uso incorrecto del gel hidroalcohólico y no respetar las distancias de seguridad interpersonal.

\begin{abstract}
"Se ha perdido mucho la conciencia del peligro del virus, sin mascarillas o mal colocadas, reunidas más personas de las permitidas, etc. Por lo que causan preocupación, ya que no están siguiendo las medidas recomendadas o restringidas"
\end{abstract}

Asociación cultural, distrito 3

También se han registrado conflictos sociales que se entienden como incoherencias con respecto a las medidas sanitarias, en cuanto al acceso a determinados centros de compras, el control de aforos en espacios cerrados, entre otras. Se ha registrado un amplio descontento con la información que se ha recibido, considerando que ha sido insuficiente en algunos casos y excesiva en otros, siempre dependiendo del medio o el canal de información y/o comunicación que emplee la persona.
Asociación de mujeres, distrito 3

Durante el periodo de pandemia, y en especial en la fase de confinamiento, se ha propiciado el uso de los medios digitales. Esto ha dado lugar a otro de los conflictos que se ha escuchado con mayor frecuencia, la brecha digital, centrada tanto en la falta de conocimientos digitales, como en la ausencia de disponibilidad de dispositivos adecuados, e incluso, en la imposibilidad de contar con un proveedor de servicios a internet estable o que provea los servicios mínimos necesarios.

\section{"El confinamiento ha puesto a la luz que hay gente que no tiene ni conocimientos tecnológicos ni los dispositivos necesarios... cosa de la que no nos habíamos dado cuenta"}

Asociación de mujeres, distrito 3

Los conflictos sociales no se distribuyen de manera homogénea en el municipio. En los distritos 3 y 4, el incumplimiento de las medidas sanitarias adoptadas contra la COVID-19 no se ha presentado con tanta frecuencia como en el resto. Sin embargo, en el distrito 3, todo se relacionaba con la información insuficiente o excesiva, y en el distrito 4, con la brecha digital, han concentrado los conflictos sociales existentes. En el distrito 6, consideran que el único conflicto social que han tenido está relacionado con el incumplimiento de las medidas sanitarias que se adoptaron. 
"Cada centro tiene un coordinador COVID que se coordina con el Centro de Salud. Pero en esta situación, aunque tienes eso, muchas veces no se sabe cómo actuar, a quién avisar" Instituto de Enseñanza Secundaria, distrito 1

\section{Conflicto profesional}

Poco más de una persona de cada tres relata un conflicto relacionado con su profesión o en su ámbito profesional. La presencia de la COVID19 ha provocado que las profesionales se vean obligadas a realizar actividades o funciones que no estaban relacionadas con sus competencias o vinculadas a su ámbito de trabajo, como por ejemplo, controlar el cumplimiento de las medidas sanitarias en los centros educativos, o dadas las circunstancias, realizar sustituciones a compañeros y compañeras en otros puestos (comedor, otras áreas, etc.). Además, relatan que han tenido que adaptarse o cambiar su forma de trabajar para poder cumplir con las medidas establecidas, e incluso, para poder seguir realizando sus funciones desde casa a través del teletrabajo. Todas estas circunstancias han derivado en una sobrecarga laboral .

"La docencia se apoyó mucho en las familias, sin embargo, no evitó que tanto ellas como otros docentes trabajaran hasta 13 horas diarias"

Asociación cultural, distrito 1

Por otro lado, se ha registrado un descontento con las administraciones públicas acerca de cómo han actuado ante esta crisis. Las personas trabajadoras se han sentido muchas veces solas ante la situación de adversidad, con una falta de información, de instrucciones y de iniciativa. Consideran que la información que se ha recibido ha sido escasa como para poder cumplir de manera adecuada con las funciones de su puesto de trabajo, sin saber la metodología a seguir, o si, simplemente, lo estaban haciendo de la forma correcta.
Si nos centramos en el análisis según la tipología de sujeto, se pueden observar diferencias en cuanto a las variantes de conflicto registrado. Las ONGs que han participado en el proceso de audición han relatado conflictos en su lugar de trabajo, por tener que readaptar su forma de trabajar, lo que ha generado sobrecarga en el personal, y en algunos casos, tener que cumplir funciones diferentes a las suyas. Además, se registra la carencia de información para poder ejercer adecuadamente su labor (falta de protocolos, etc.)

En los centros públicos de Educación Infantil y Primaria, se registran con mayor frecuencia conflictos relacionados con la Administración, derivados de la falta de coordinación entre ésta y los centroWs, sumado a la dificultad a la hora de controlar el cumpliento de las normas por parte del alumnado y las familias. Además, debido al cumplimiento de funciones diferentes en el centro (sustituir compañeros en cuarentena porque no se cubre la vacante a tiempo) y al seguimiento del alumnado desde casa (durante y después del confinamiento), el personal docente se ha enfrentado a una sobrecarga de trabajo. 
"Me planteo dónde voy a tomarme un café, por ejemplo. Y si veo que en el local hay mucha gente, me agobio"

\section{Conflicto personal}

Solo una de cada diez personas manifiesta un conflicto personal durante el Proceso de Audición. Aún estando presentes, se demuestra que los conflictos no se ubican de manera preferente en el ámbito de la persona, que ha sabido gestionarlos, en buena medida, o que, simplemente, no han surgido. No obstante, los que se han identificado se relacionan de forma estrecha con la traslación de impactos negativos, que en el ámbito de la persona han supuesto un conflicto. Evidencia de esto es que la concentración de conflictos se halle en la disminución del contacto social, el estar lejos de la familia o no poder mostrar afecto a las personas apreciadas, como besos o abrazos.

\section{"He tenido que traer a mi abuela a casa para que no estuviera sola durante la cuarentena"}

Organización No Gubernamental, distrito 2

Otra traslación a la esfera personal también se hace desde el impacto social, donde las personas, esta vez de manera individual, relatan la incoherencia que les supone la aplicación de las medidas sanitarias establecidas, como la atención médica sólo por vía telefónica, frente a la convicción de que una atención presencial es mejor para realizar un buen diagnóstico; o el dilema que supone que las personas hagan deporte sin mascarilla por la calle, emitiendo aerosoles a su paso y, en especial, haciendo hincapié en la ansiedad que les supone el incumplimiento de las medidas por parte de otras personas. La pandemia ha supuesto un cambio de estilo de vida para muchas personas, teniendo que modificar sus rutinas y prioridades, las que estaban llevando hasta el momento en el que apareció la pandemia en su día a día. 


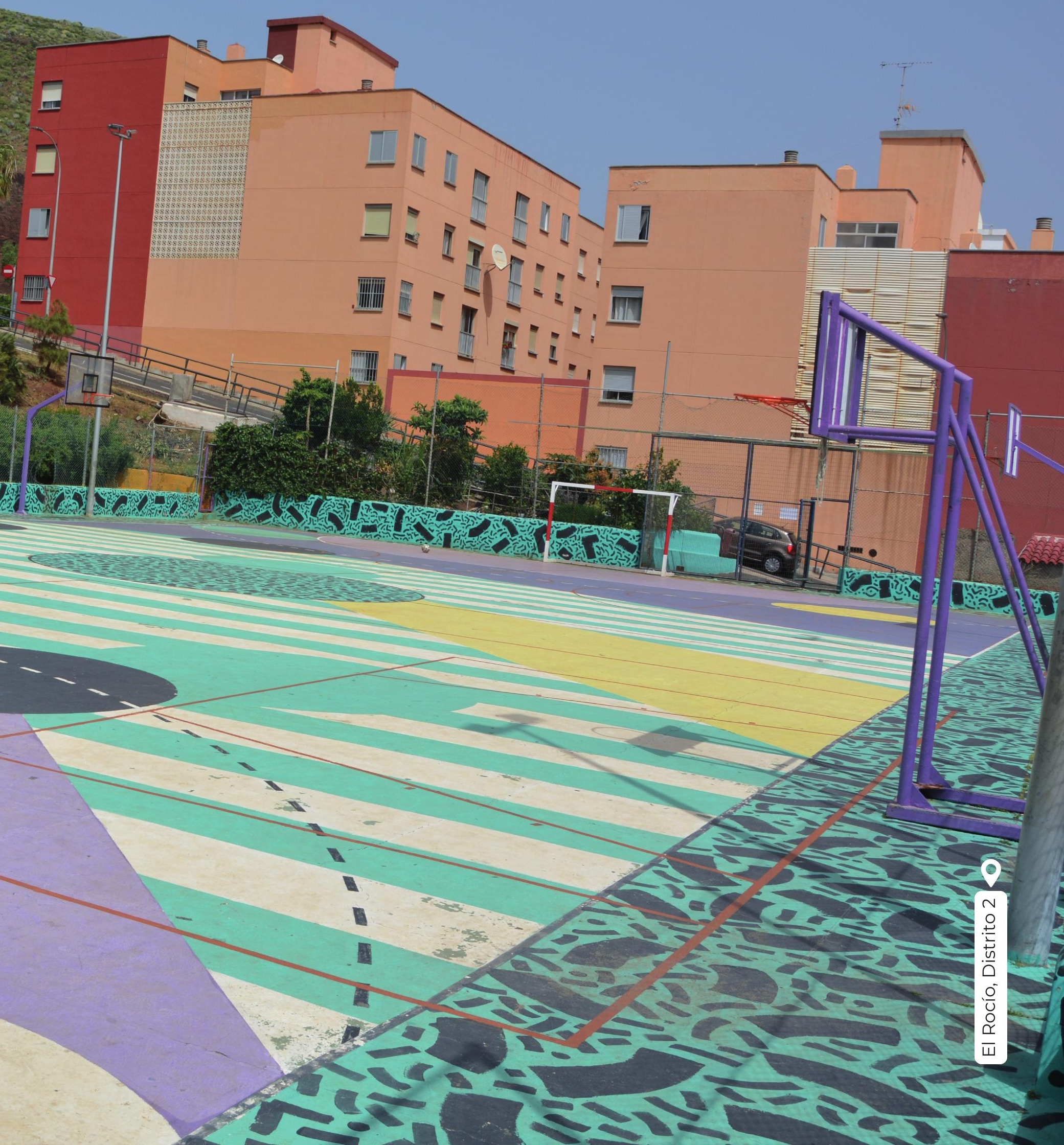




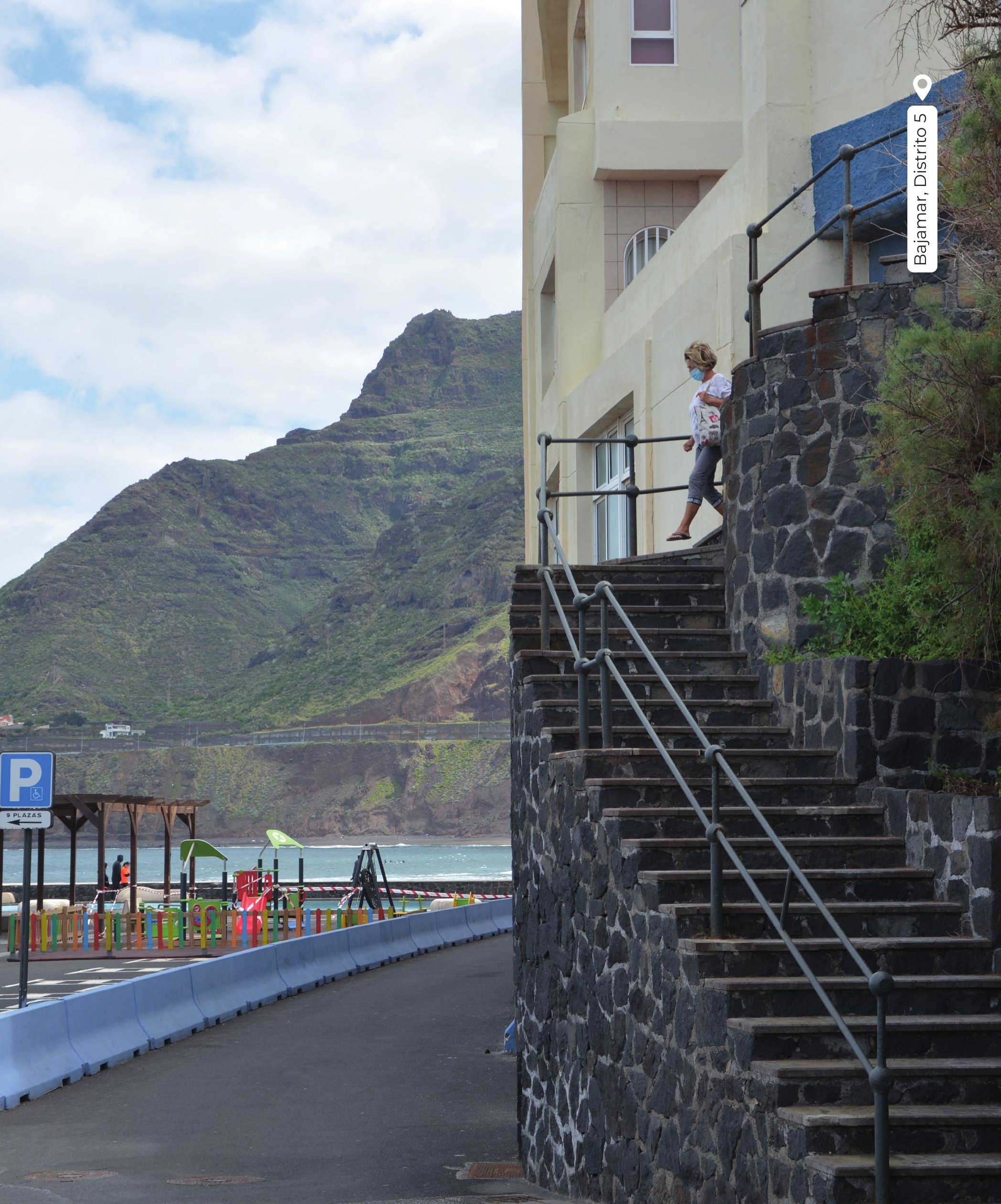




\section{Aprendizajes}

Los aprendizajes, aunque han existido, todavía quedan por generarse, más si cabe, conocidos los conflictos existentes en la comunidad. De cada 100 personas de la comunidad, sólo 34 manifiestan haber obtenido algún aprendizaje tras un año de pandemia. Los aprendizajes se irán adquiriendo en la medida en que se vayan gestionando de manera adecuada, y en el mejor de los casos, resolviendo los conflictos. A diferencia de estos, son los aprendizajes profesionales (19\%) los que más presentes están en los relatos de las personas escuchadas, en comparación con los aprendizajes sociales (17\%). Mientras, continúan siendo los aprendizajes en el ámbito personal los que menos se manifiestan, quizá, de manera respectiva, vinculado con la menor presencia de conflictos personales.

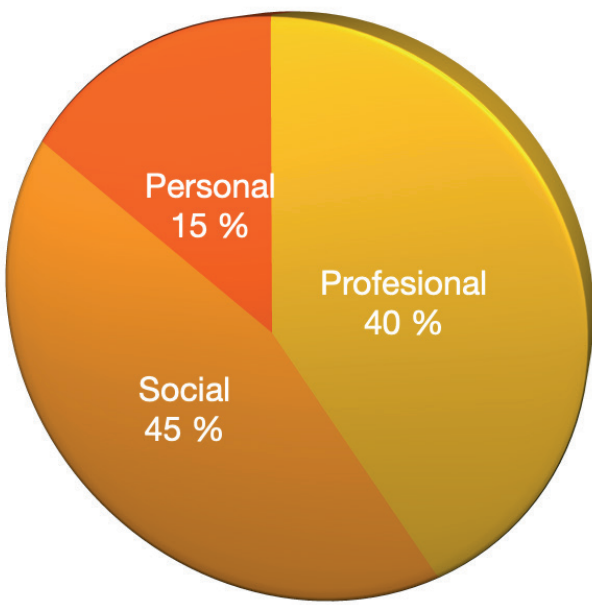

$100 \%$

$75 \%$

$50 \%$

$25 \%$

Fuente: Proceso de Audición del Proyecto Comunidad. Elaboración propia 
"Continuamos con los métodos empleados durante el confinamiento en la dinámica normal del colegio, debido a los beneficios que se obtienen de este método tanto para las familias como mejorando la labor del profesorado"

Centro de Educación Infantil y Primaria, distrito 1
"Las actividades de sensibilización en centros educativos y empresas eran presenciales, ahora todo se hace a través de la vía digital, aunque extrañamos la parte presencial reconocemos que este medio también es muy positivo"

Organización No Gubernamental, distrito 2

\section{Aprendizaje social}

Casi dos de cada diez personas relatan que han adquirido un aprendizaje en el ámbito profesional o en su desempeño laboral. Se ha constatado que las formas de trabajo que se conocían hasta ahora han cambiado y que, por lo tanto, pueden continuar cumpliendo las mismas funciones o alcanzando los mismos objetivos, en su mayoría, también desde sus casas. Esto ha fomentado que muchos y muchas profesionales hayan tenido que adaptar los procedimientos y la metodología de trabajo para poder continuar con su actividad, contactando con otras áreas, asumiendo otras funciones o reorganizando actividades. Una de las formas más utilizadas ha sido adaptar el contenido al formato digital, a través de diversas plataformas, apps y/o redes sociales.

El aprendizaje ha variado según la tipología de sujeto que ha participado. Las ONGs, centros educativos, tanto de infantil y primaria como de secundaria, la Administración y sus recursos, han señalado que, debido al hecho de tener que modificar su metodología de trabajo y adaptar el contenido a esquemas digitales, han adquirido nuevas habilidades. Por otro lado, en especial las farmacias y las escuelas infantiles, tanto públicas como privadas, también han tenido que modificar su forma de trabajar y relatan,
Cerca de dos de cada diez personas también relatan un aprendizaje desde el ámbito social. Tras la irrupción de la pandemia, se ha aprendido la importancia de vivir en comunidad y que somos más fuertes unidas, que no se puede avanzar en la vida ni construir comunidad de manera individual. Se ha aprendido que no se puede vivir ignorando lo que le pasa a la persona de al lado, ya que es importante poder tender la mano cuando se necesite. Pasar por una situación como la provocada por la COVID-19 ha ayudado para que se valore más a las personas, el afecto humano y las relaciones. Además ha sido importante el trabajo en red, para conocer poder ayudar entre todos y todas.

\section{"La ciudadanía organizada es la mayor esperanza; y con un gran nivel de resiliencia y aguante"}

Administración Local, distrito 1 lo que se está haciendo en el municipio y así 
"Me quedaría con la lección que muchos

de ellos nos han dado, que no solo es la

vía digital, sino también la humana, el

apoyarse unos a otros, el no abandonarse"

Escuela Infantil, distrito 1

\section{Aprendizaje personal}

Casi una de cada veinte personas manifiesta un aprendizaje en el ámbito personal. En este caso, la escasez de aprendizajes se debe más a la ausencia de conflictos personales, que a la falta de gestionar o resolver los que existen. Teniendo en cuenta esto, la presencia de la COVID-19 en el municipio ha propiciado aprendizajes personales en la comunidad. De manera especial, el hecho de tener que enfrentarse a una nueva forma de vida durante el confinamiento, ha fomentado la capacidad de reinvención y la creatividad para modificar sus rutinas o hábitos de vida, para buscar soluciones y poder continuar con los mismos, por ejemplo, aprendiendo a usar tecnologías que antes no se conocían. Ahora se valora más a las demás personas, las relaciones humanas y el valor de lo que se tiene. Para las personas de la comunidad que les ha supuesto un aprendizaje, la pandemia les ha permitido que puedan realizar un ejercicio de introspección, pensar, reorganizar sus vidas y centrarse en lo importante.

"Cada centro tiene un coordinador COVID que se coordina con el Centro de Salud.

Pero en esta situación, aunque tienes eso, muchas veces no se sabe cómo actuar, a quién avisar"

Instituto de Enseñanza Secundaria, distrito 1 


\section{Propuestas de mejora}

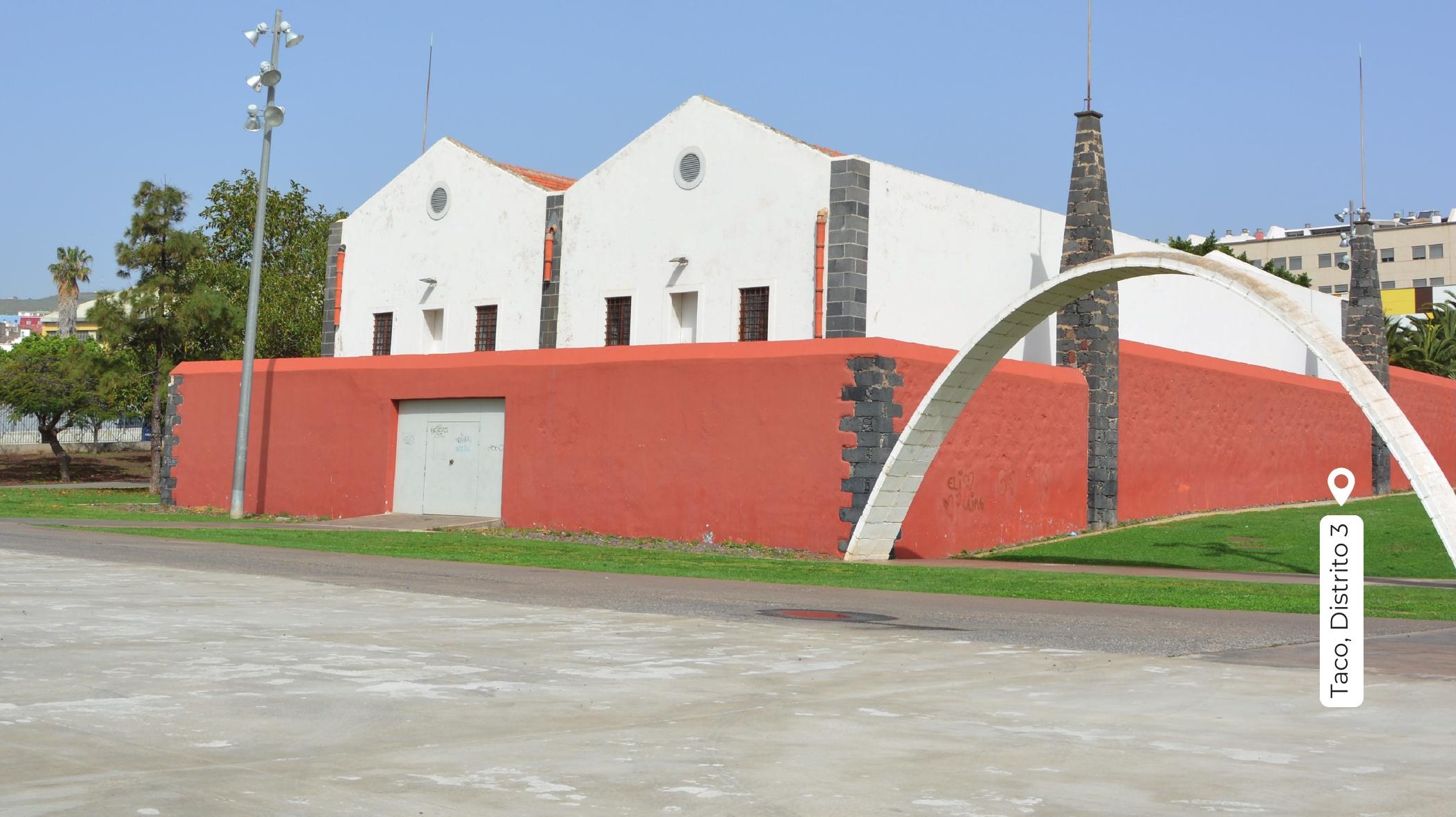


En el contexto del Proceso de Audición para la elaboración de la parte subjetiva de la Monografía Comunitaria "La COVID-19 en San Cristóbal de La Laguna: una mirada desde la comunidad", también se interpelaba a las personas escuchadas para que realizaran propuestas de mejora.

Las propuestas, al igual que el contenido de los relatos que las personas compartían, las realizaban con sus propios criterios de necesidad o prioridad. Solo se les formulaba una pregunta sobre qué consideraban que podía ayudar a mejorar la situación actual. Se identificaron 733 propuestas, repartidas entre las once dimensiones de análisis, en las que, aproximadamente una de cada tres, se relacionaron con la dimensión Sociedad.

A continuación se muestran las propuestas agregadas por dimensiones. $Y$ dentro de las mismas, se priorizan de mayor a menor según hayan aparecido iguales propuestas o muy similares en los relatos de diferentes personas.

Esta relación de propuestas es una devolución ordenada de información tras el proceso de audición, no se establece como medidas a realizar. Es importante recordar que el Proceso de Audición y la elaboración de la Monografía Comunitaria se ha extendido varios meses, y por tanto, las propuestas pueden hacer referencia a las necesidades que se creyeron necesarias en los momentos concretos en los que las personas las expresaron.
Relación de propuestas según dimensiones analizadas en el proceso de audición (\%)

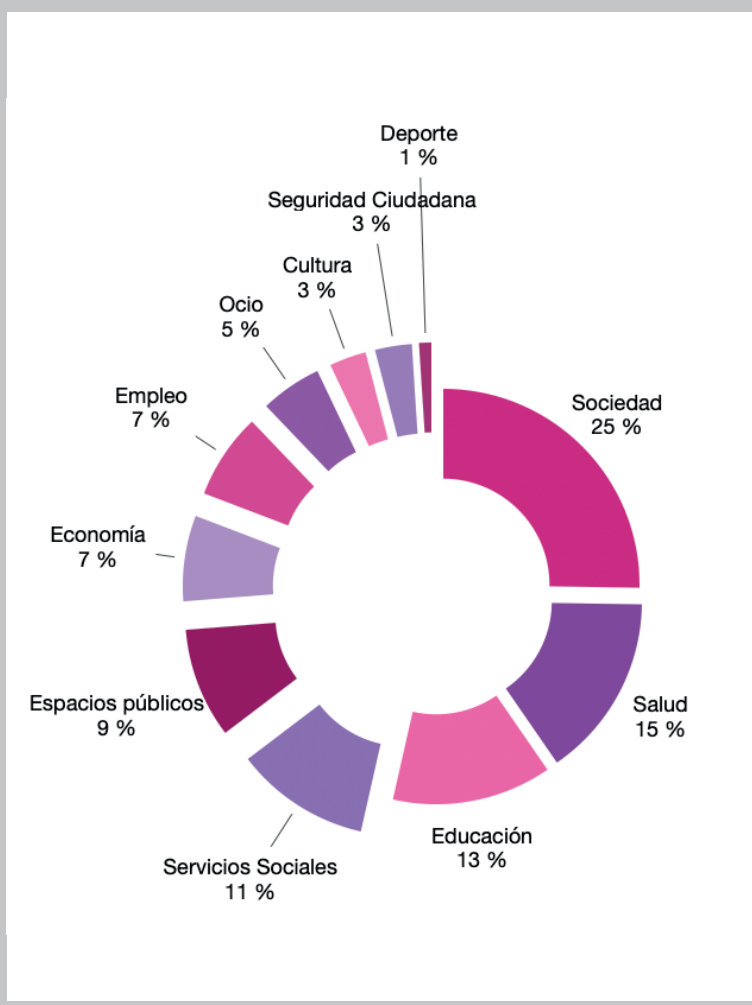

Fuente: Proceso de Audición del Proyecto Comunidad. Elaboración propia

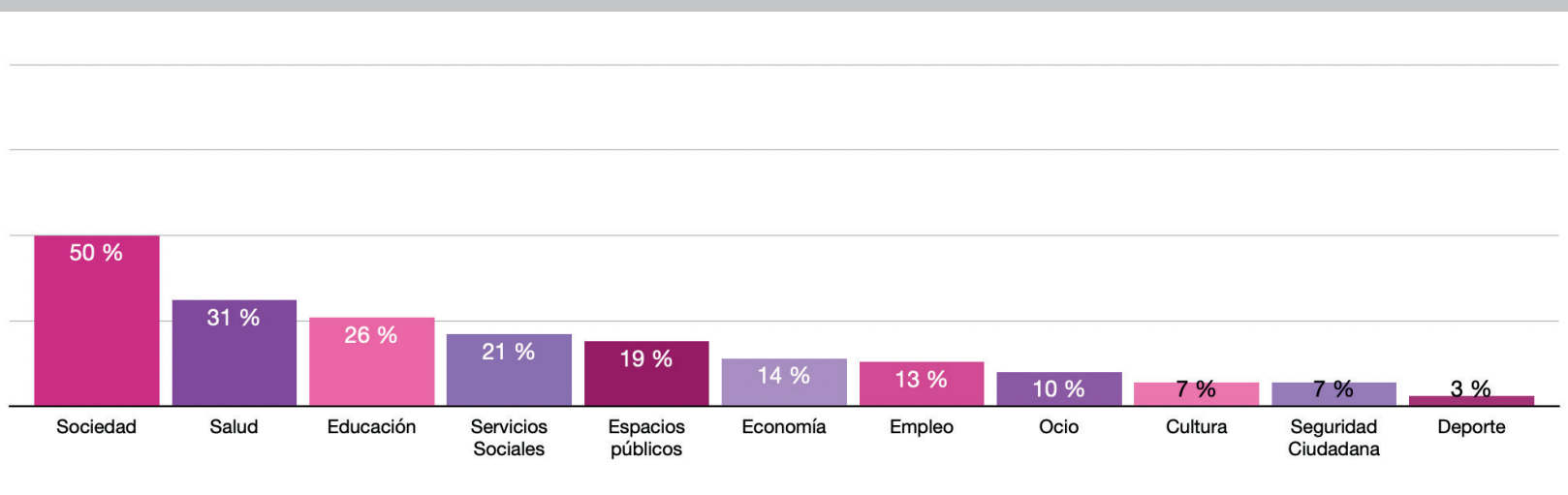

Fuente: Proceso de Audición del Proyecto Comunidad. Elaboración propia 
D.

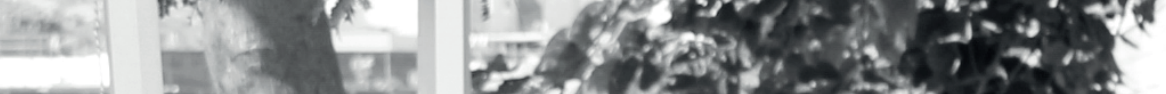

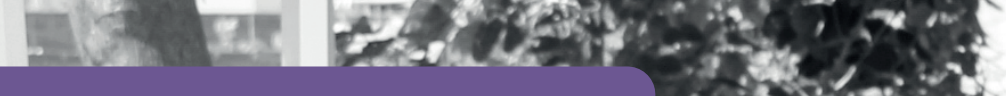

Sociedad

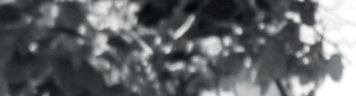

$7, \ldots, 0,1$

सी

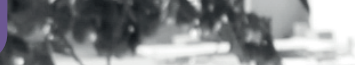
ins 1 is

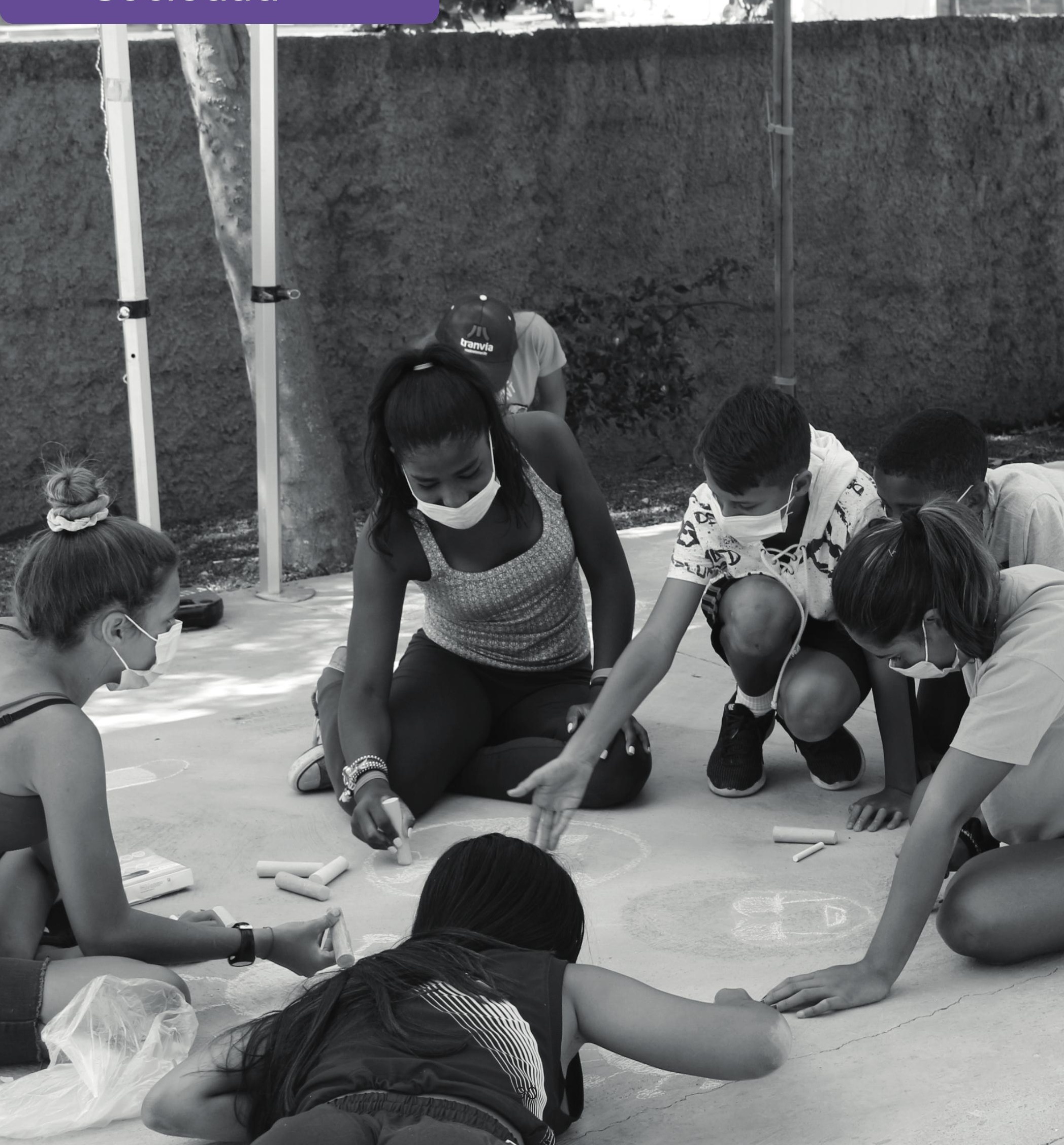


Formación de competencias digitales a la ciudadanía y a las entidades sociales para paliar la Brecha Digital.

2) Escuchar y crear foros de diálogo con los diferentes colectivos y agentes sociales del municipio de San Cristóbal de La Laguna antes de implementar medidas y diagnosticar lo vivido como sociedad.

\section{3) Ofrecer por parte del Ayuntamiento de} San Cristóbal de La Laguna información real y cercana a la ciudadanía, diversificando los canales de difusión.

\section{4) Crear programas de voluntariado,} grupos de apoyo comunitarios y servicios que mantengan los originados durante el confinamiento y se dediquen al acompañamiento y otros tipos de ayudas requeridas por la comunidad.

5) Aumentar las ayudas públicas y una mejora de la atención a la ciudadanía por parte de las administraciones públicas.

6) Desarrollo de programas que potencien el trabajo en red del tejido asociativo y su adaptación a las nuevas necesidades colectivas.

7) Fortalecer la comunicación y coordinación entre las instituciones públicas, sus intermediarios y la ciudadanía en general.

8) Fortalecer las redes de apoyo mutuo surgidas en el confinamiento.

9) Facilitar la gestión burocrática de entidades sociales y personas, reforzando la presencialidad y eliminando documentación.

10) Potenciar las asociaciones locales para crear una gran red de colaboración en cada barrio.
11) Atención a la parte psicosocial a través de proyectos sociales y estudios centrados en el empoderamiento, el autoconocimiento y las técnicas para afrontar situaciones de estrés.

12) Promover la formación en valores ciudadanos, empatía y acogida.

13) Apoyar la creación de proyectos y entidades dedicadas a evitar la "infoxicación" y la desinformación e intervenir para combatir los bulos.

14) Las administraciones públicas deben hacer más de lo que están haciendo, pasando de políticas asistencialistas a políticas sociales activas.

15) Creación de nuevos espacios de participación ciudadana en el ámbito virtual.

16) La implementación en los barrios desde el Ayuntamiento de San Cristóbal de La Laguna de recursos dirigidos a la eficiencia energética, como las energías renovables o la conciencia ambiental.

17) Acciones de sensibilización a la población joven en torno a las consecuencias de la COVID-19.

18) Ahondar más por parte del Ayuntamiento de San Cristóbal de La Laguna en la colaboración con la Universidad de La Laguna.

19) Elaboración de una aplicación que recoja y geolocalice experiencias sociales en el municipio de San Cristóbal de La Laguna.

20) El tratamiento de objetivos relacionados con la sostenibilidad del territorio frente a la COVID-19 en proyectos como Comunidad.

21) Un fichero de recursos sociales donde se especifique de forma clara la función de cada uno y poder ofrecer servicios de manera eficiente, organizada y dinámica. 


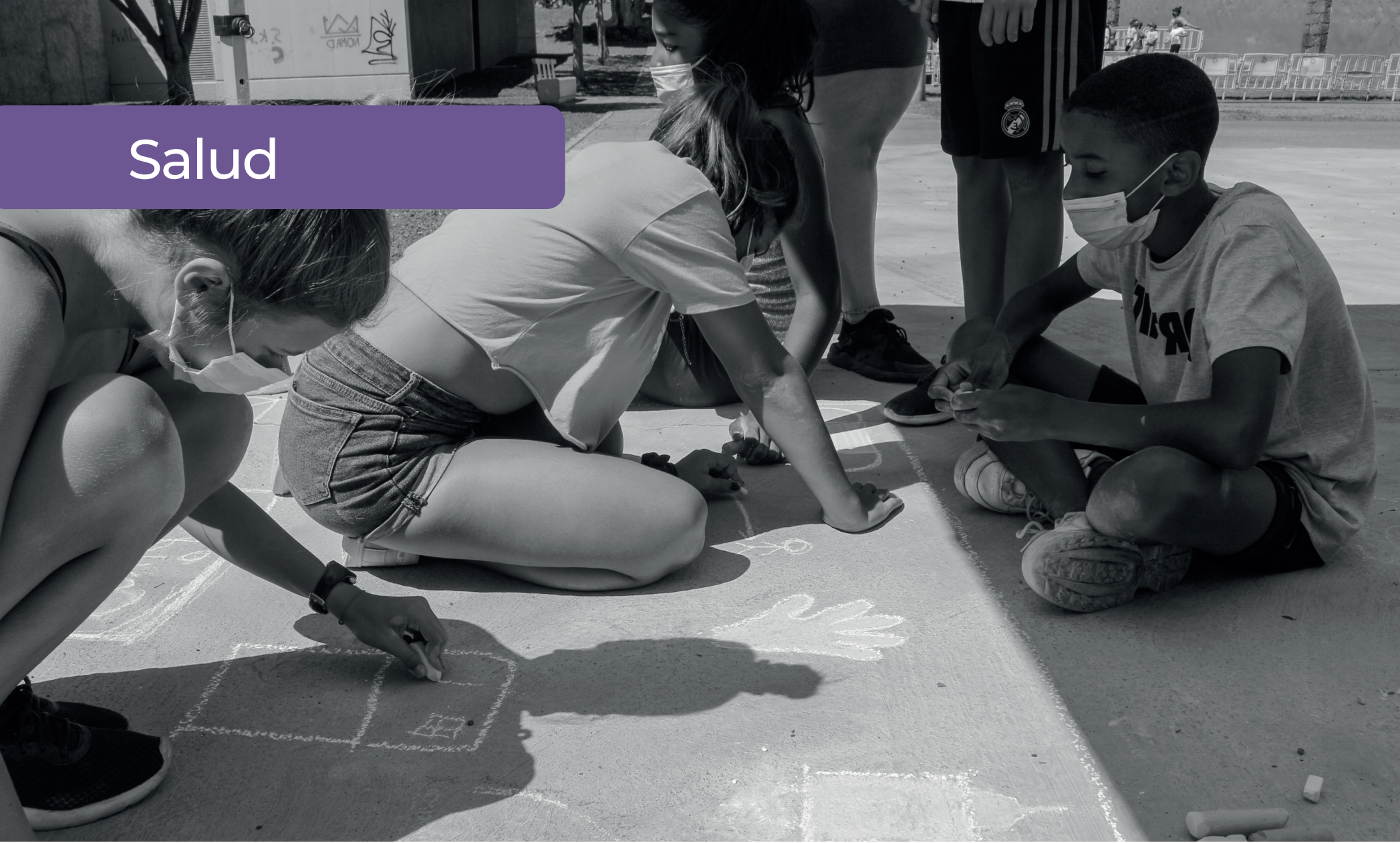

1) Aumentar la supervisión del cumplimiento de las medidas sanitarias, sobre todo cuando las personas se encuentran en cuarentena, por ejemplo, creando un grupo de personas que vaya por las zonas más concurridas de cada barrio.

2) Ofrecer información sanitaria relativa a la COVID-19 de forma clara y que llegue a toda la población, por ejemplo cómo actuar ante un caso de COVID-19 y cómo se puede prevenir.

3) Ofrecer apoyo psicológico a las familias.

4) Mejorar las campañas de prevención y mantenerlas en el tiempo.

5) Habilitar espacios al aire libre donde poder realizar actividades que promuevan tanto la salud, como el deporte o la cultura.
6) Contar con la figura fija de una persona sanitaria en los centros educativos, sobre todo para temas de COVID-19, higiene dental, educación sexual, alimentación saludable, etc.

7) Fomentar la comunicación y coordinación entre los Centros de Salud y los recursos sanitarios del municipio de San Cristóbal de La Laguna, los centros educativos, etc., para una mejor atención a la ciudadanía

8) Reforzar el personal en los Centros de Salud, incluyendo psicólogos y fisioterapéutas, pero sobre todo para acelerar el proceso de vacunación. 
9) Utilizar diferentes formas de transmitir información sanitaria a la ciudadanía, como por ejemplo, habilitar un canal de televisión $24 \mathrm{~h}$ sobre el tema, crear paneles o frases cortas y concisas con la información o poner anuncios de cómo se contagia la COVID-19, tal y como los de cáncer en las cajetillas de tabaco.

10) Mantener en el tiempo las citas telefónicas y la digitalización de los documentos en los Centros de Salud, como por ejemplo, las recetas.

11) Permitir a las farmacias realizar otras funciones, como transmitir información fiable - liberar la carga de trabajo de los Centros de Salud, con acciones como inyectar la insulina, vacunar contra la gripe o realizar la entrega de medicación a domicilio.

12) Favorecer que en las farmacias se puedan realizar pruebas de antígenos y adaptarlas para ello, como por ejemplo poner biombos para garantizar la privacidad de las personas.

13) Facilitar la creación de un teléfono al que las personas puedan Ilamar para consultar sus dudas sobre la situación sanitaria actual, o simplemente, hacer frente a su soledad, sobre todo pensando en las personas mayores.

14) Exigir certificado negativo de COVID-19 a turistas.

15) Mejorar la detección de la COVID-19 en los centros educativos, realizando test de antígenos cada dos semanas al profesorado y equiparlo con los medios de protección adecuados, facilitando pantallas de control de temperatura y mascarillas a los centros educativos, incluyendo mascarillas transparentes para el equipo TEA y logopedas.

16) Dotación de mascarillas a la población por parte de la administración pública sin coste alguno.

17) Realizar charlas y formación al alumnado de los centros educativos en materia de prevención de la COVID-19 y salud en general.
18) Reducir el coste del material de protección ante la COVID-19, como las mascarillas o destinar ayudas para ello.

19) Que la información sobre la COVID-19 sea transmitida a la ciudadanía por personal sanitario, por ejemplo acudiendo a plazas o sitios públicos accesibles a todos los colectivos.

20) Priorizar la atención presencial en los Centros de Salud.

21) Realizar cribados por barrios para facilitar el acceso de la ciudadanía, ya que muchas personas no disponen de medios de transporte para trasladarse, por ejemplo, montando una carpa en la plaza del barrio.

22) Concienciar a las familias de la importancia del cumplimiento de las medidas sanitarias decretadas para evitar el contagio de la COVID-19.

23) Aumentar la limpieza en los espacios públicos como plazas o calles muy transitadas.

24) Habilitar espacios donde los niños y niñas puedan relacionarse sin necesidad de usar la mascarilla.

25) Normas generales para todos los municipios.

26) Reforzar el personal en las Escuelas de Infantil.

27) Mantener el aforo limitado en las aulas de los centros educativos, teniendo en cuenta el personal que hay en dichos centros.

28) Mantener en el tiempo los cambios estructurales realizados en los Centros de Salud y hospitalarios, como las zonas de aislamiento, salidas independientes, pediatría alejada de zona de adultos, etc. 
29) Realizar confinamientos por municipios más afectados, de forma que se pueda evitar la masificación de personas en determinados comercios.

30) Fomentar el cumplimiento de las normas sanitarias por parte de toda la población para evitar la propagación de la COVID-19.

31) Elaborar un plan de atención a la persona mayor.

32) Fomentar el uso de la teleconsulta médica, para facilitar la identificación de los/as pacientes por parte del personal sanitario.

33) Concienciar sobre la racionalidad del uso de los servicios de salud y mejorar la independencia de la ciudadanía para valorar cuándo acudir al Centro de Salud.

34) Facilitar el acceso a la atención de salud mental, promoviendo que las citas sean rápidas y asequibles para toda la población.

35) Mantener en el tiempo las medidas sanitarias establecidas, ya que están contribuyendo a menores índices de gripe.

36) Establecer horarios en los que las personas pueden acudir a las farmacias para facilitar su atención.

37) Prohibir las mascarillas no homologadas.

38) Mejorar el servicio de atención telefónica de los Centros de Salud.

39) Asegurar la protección del personal sanitario en caso de volver a vivir una situación como la COVID-19.

40) Promocionar la seguridad sanitaria en el sector cultural.

41) Crear unas mascarillas más ergonómicas.
42) Facilitar la continuidad de la formación online a las personas de riesgo alto.

43) Limitar el aforo de aquellas calles que son más transitadas o tienen terrazas.

44) Poner carpas en las entradas de los Centros de Salud para que las personas tengan cobijo mientras esperan.

45) Hacer que las personas jóvenes que han incumplido las medidas sanitarias, cuiden de personas mayores o estén en urgencias viendo la afectación de la COVID-19.

46) Desinfección en todas las puertas de los Centros Educativos.

47) Instalar un consultorio en Bajamar, de esta forma se reducirá la carga de trabajo de los Centros de Salud próximos.

48) Llevar a las escuelas más formación sobre inteligencia emocional, eliminar el individualismo, trabajar en red.

49) Aumentar la cantidad de dispensadores de gel hidroalcohólico en las farmacias.

50) Trabajar la vulnerabilidad social que está generando la COVID-19. 


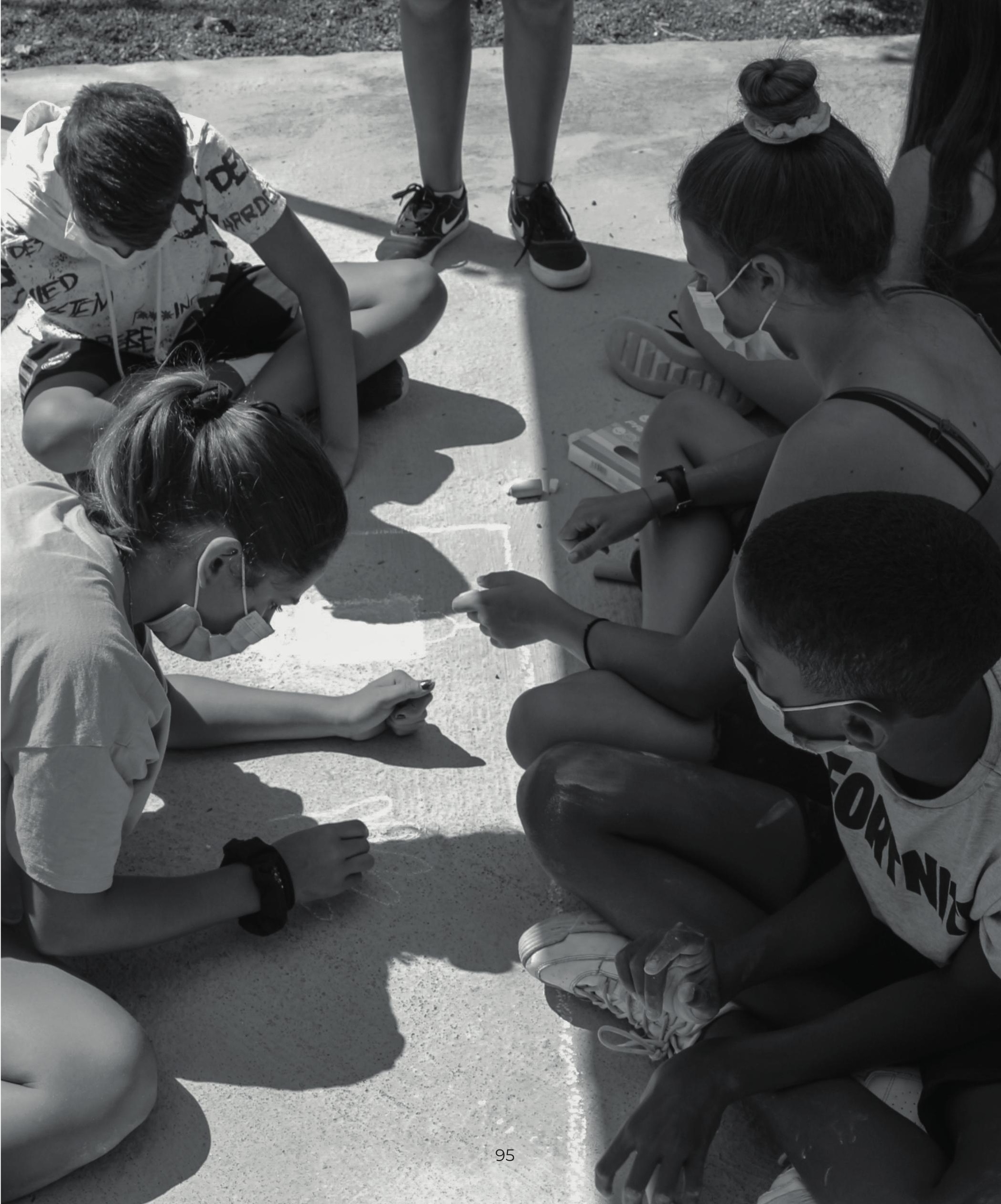


1) Formar en el uso de herramientas digitales a la comunidad educativa y afrontar la brecha digital.

2) Fortalecer la coordinación entre las administraciones públicas para que los recursos educativos lleguen de manera equitativa a todo el alumnado.

3) Reforzar el personal profesional no docente (psicología, trabajo social, sanitario, limpieza, etc.) de los Centros Educativos.

4) Ofrecer un servicio de apoyo emocional y psicológico, además de información sanitaria para el alumnado y sus familias.

5) Aumentar el control por parte de las administraciones sobre las medidas y suministros de materiales anticovid en los Centros Educativos.

6) Sensibilizar desde los institutos a las personas jóvenes sobre las consecuencias y el peligro real de la COVID-19.

7) Reducir los grupos de alumnado para ofrecerles un trato más individualizado y una mejor atención de sus necesidades.

8) Realizar talleres en los Centros Educativos sobre comportamiento cívico y medidas de protección sanitaria.

9) Aumentar la presencia del Ayuntamiento de San Cristóbal de La Laguna en los centros escolares públicos del municipio.

10) Establecer una comunicación más directa entre los organismos públicos (Consejerías de Sanidad y Educación, sobre todo) y los Centros Educativos.

11) Creación de aulas de naturaleza o huertos escolares para la educación ambiental de los niños y niñas.

12) Fomentar servicios de atención temprana y recepción del alumnado en los Centros Educativos
13) Apoyar a las AMPAS como enlace entre las familias y los Centros Educativos.

14) Reforzar el desarrollo de la inteligencia emocional y los valores éticos en los Centros Educativos.

15) Fortalecer la relación entre los Centros Educativos y la comunidad, implicando al alumnado en su entorno social.

16) Crear Escuelas Infantiles públicas en zonas del municipio de San Cristóbal de La Laguna que no disponen de ellas.

17) Promover la formación no formal adaptada a las necesidades de la población local.

18) Crear una plataforma online para los Centros Infantiles.

19) Ofrecer más ayudas económicas a las familias para que lleven a los niños y niñas a los Centros Infantiles.

20) Mantener abiertos los Centros Infantiles en vacaciones y en verano.

21) Insonorizar zonas de los Centros Educativos para ayudar al alumnado con Trastorno del Espectro Autista (TEA).

22) Favorecer la semipresencialidad en la Enseñanza Universitaria.

23) Escuchar a toda la comunidad universitaria antes de tomar decisiones.

24) Aumentar la financiación de la Universidad pública.

25) Utilizar al personal universitario para diagnosticar y proponer soluciones sociales. 
1) Reforzar el personal de los Servicios Sociales y desburocratizar el servicio de atención a la ciudadanía.

2) Aumentar el asesoramiento y la información por parte del Ayuntamiento de San Cristóbal de La Laguna en torno a la tramitación de ayudas sociales a las personas.

3) Crear redes de colaboración entre organizaciones, colectivos e instituciones públicas para atender las necesidades existentes a nivel local.

4) Servicio de atención personalizada a las personas mayores para la gestión online de ayudas y recursos administrativos.

5) Afianzar la comunicación entre las administraciones públicas de quienes dependen los colectivos vulnerables.

6) Invertir en más proyectos sociales que aporten ayudas y servicios sociales a la población.

7) Apostar por nuevos recursos de ayuda a domicilio.

8) Crear un programa de búsqueda de alternativas de alojamiento y alquiler de viviendas.

9) Aumentar las ayudas sociales y materiales públicos.

10) Programar formaciones desde las administraciones públicas sobre gestión de los recursos y de consumo eficiente para las familias que reciben ayudas económicas.

11) La Concejalía de Bienestar Social debe ofrecer la información transparentemente de las familias y personas que solicitan ayuda en el municipio de San Cristóbal de La Laguna.

12) Crear un equipo de voluntariado municipal de acompañamiento y ayuda a colectivos desfavorecidos y personas vulnerables.
13) Poner en marcha estrategias alternativas para la atención administrativa a la comunidad sorda.

14) Iniciar un diagnóstico social, contando con las experiencias de los trabajadores sociales, para planificar más eficientemente futuras mejoras de los Servicios Sociales.

15) Adaptar la revisión de la renta para recibir ayudas sociales a los meses anteriores a la solicitud, en vez de tener en cuenta la renta del año anterior.

16) Implementar más acciones de inclusión social, seguimiento y apoyo de colectivos con discapacidad y problemas de salud mental.

17) Servicio de acompañamiento telefónico y seguimiento a la ciudadanía de los barrios. 


\section{Espacios Públicos}

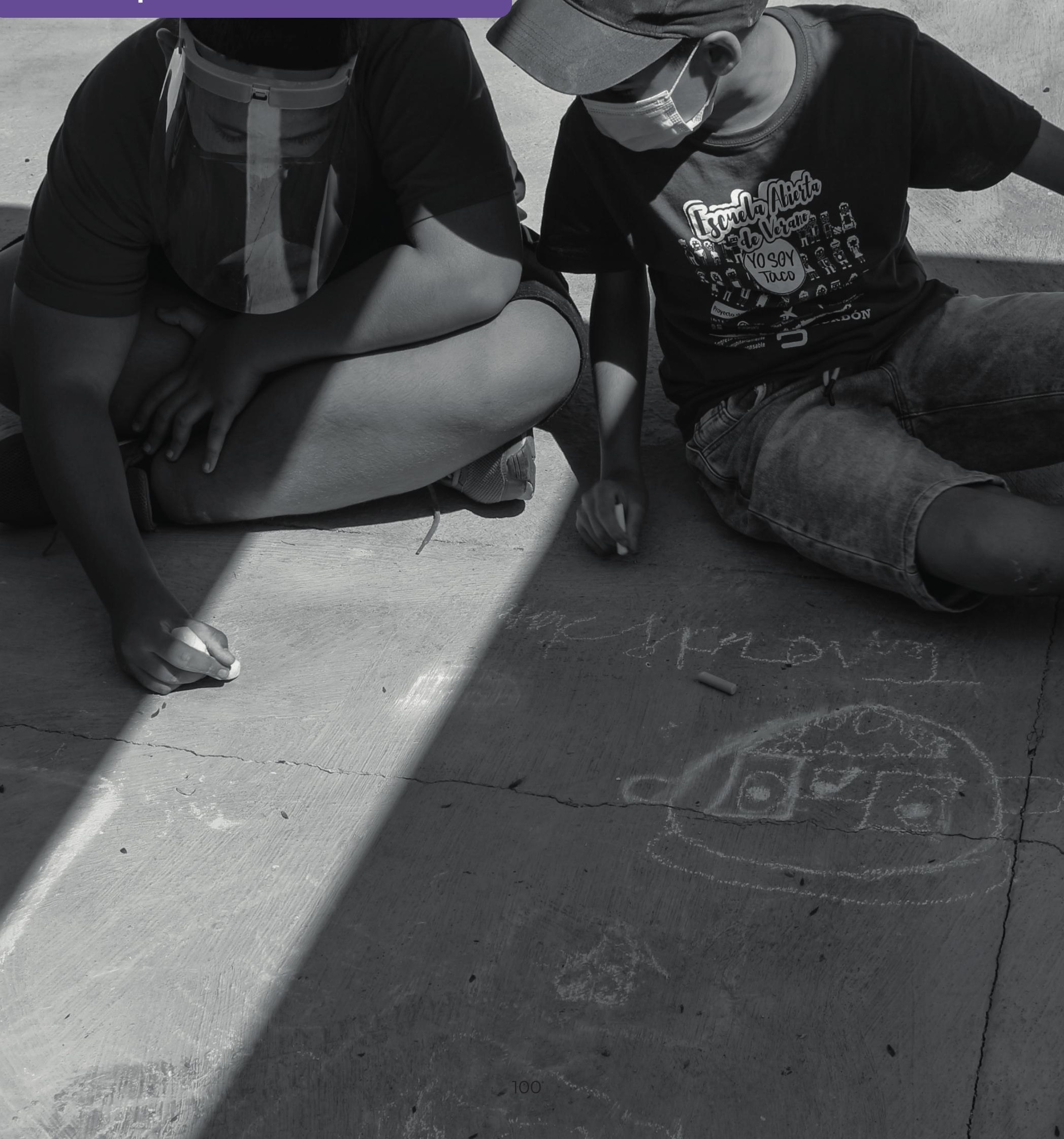


Reabrir los Centros Ciudadanos con horarios restringidos y limpieza intensiva.

2) Utilizar los Centros Ciudadanos como espacio de apoyo extraescolar y de acceso público a la tecnología digital.

3) Utilizar lugares públicos como los parques para comunicar acerca de la COVID-19.

4) Utilizar los Centros Ciudadanos como espacios de coworking para la ciudadanía y para gente emprendedora sin espacios de trabajo.

5) Adaptar azoteas de centros públicos y otros espacios abiertos para uso ciudadano.

6) Reacondicionar los carteles sobre medidas anti COVID que se encuentran en espacios públicos y actualizar su información constantemente.

7) Extender los espacios de Wifi gratuitos en los espacios públicos.

8) Reforzar el personal dinamizador de los Centros Ciudadanos.

9) Controlar el uso de los Centros Ciudadanosy mantenerlo con actividades a puerta cerrada.

10) Realizar un inventario de todos los materiales que hay en los Centros Ciudadanos y extender su uso a toda la ciudadanía interesada.

11) Utilizar los centros sanitarios públicos como lugares de reparto de material sanitario.
12) Aumentar el uso de las infraestructuras públicas como espacios de reunión vecinal.

13) Informar a la sociedad sobre la situación de los Centros Ciudadanos y su posibilidad de apertura

14) Extender las calles peatonales con un solo sentido para controlar el tránsito.

15) Mantener el nivel de limpieza y desinfección de los espacios públicos. 


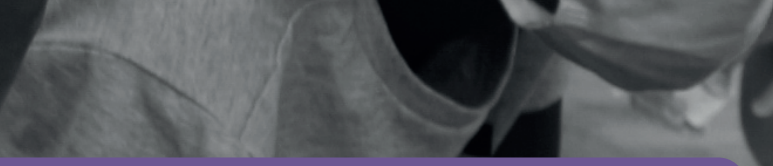

20

Economía

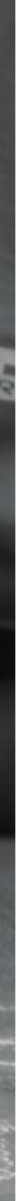
1. 301
in
1

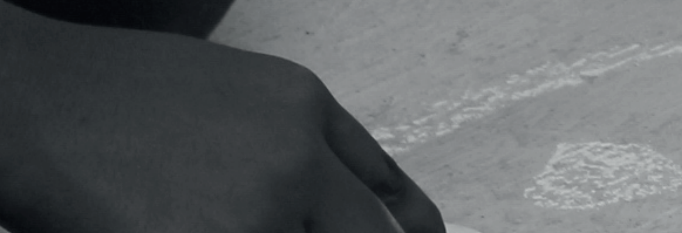


1) Adaptar las ayudas económicas a la realidad comercial de los barrios y pueblos y fomentar el comercio local.

2) Diversificar la economía, evitando centrarse en el turismo y el sector servicios.

3) Crear foros sociales y espacios de diálogo entre los comerciantes, la ciudadanía y las instituciones públicas para gestionar los presupuestos municipales.

4) Diseñar campañas publicitarias directas y dirigidas al consumo en el municipio desde plataformas del Ayuntamiento de San Cristóbal de La Laguna.

5) Iniciar un proceso de escucha por parte de las administraciones públicas con el pequeño comercio y profesionales de cada sector para conocer sus experiencias, soluciones e inconvenientes sufridos.

6) Promover la economía circular y reducir el consumo de recursos no sostenibles.

7) Quitar cargas fiscales municipales, regionales o estatales a las empresas y autónomos que siguen en funcionamiento.

8) Controlar a las grandes superficies y establecer un trato igualitario con el pequeño comercio.

9) Facilitar el establecimiento de terrazas al aire libre en el sector hostelero.

10) Establecer un seguimiento, desde las instituciones públicas, de la situación de los comercios para evitar su llegada a una situación de quiebra.

11) Favorecer la modernización tecnológica de los comercios.

12) Regulación por parte de las instituciones de los alquileres de los inmuebles del municipio de San Cristóbal de La Laguna.
13) Controlar el aumento de las franquicias en las zonas comerciales pequeñas.

14) Mayor cercanía de los agentes de empleo y desarrollo local con las empresas y los perfiles profesionales.

15) Aumentar las ayudas a la hostelería y al turismo.

16) Mapear las estrategias económicas, iniciativas empresariales y nuevos nichos de empleo como modelo de buenas prácticas.

17) Aumentar la financiación pública de proyectos con beneficios en aumento. 
1) Trabajar en la creación de más oportunidades de empleo además de la hostelería y el turismo, así como en la concienciación de la población sobre estos nuevos empleos y sobre qué formación deben tener para acceder a ellas.

2) Aumentar el número de contrataciones para profesionales de los Centros Educativos, incluso cuando haya pasado la crisis sanitaria. Es necesario incorporar nuevos perfiles como psicólogos, trabajadores sociales, educadores sociales y personal sanitario. También se necesitan refuerzos en puestos actuales, como el personal docente y el personal cuidador de comedor escolar.

3) Realizar pequeñas actividades con control sanitario para que se puedan generar empleos, como por ejemplo, pequeñas fiestas, actividades al aire libre relacionadas con cultura, música y deportes, que puedan suponer una fuente de empleo y que San Cristóbal de La Laguna puede ofrecer como ciudad cultural.

4) Ofrecer mayores bonificaciones a las empresas para la contratación de las personas jóvenes sin apenas experiencia profesional para poder mejorar su posibilidad de encontrar un empleo.

5) Bajar los tributos y flexibilizar pagos, logrando que el Ayuntamiento de San Cristóbal de La Laguna rebaje la presión fiscal a los pequeños negocios.

6) Ofrecer formación en el manejo de nuevas tecnologías, capacitar a las personas en cómo hacerse un correo electrónico, cómo acceder a la clave PIN, cómo escanear documentos, cómo realizar un currículo, etc.

7) Dar trabajo a las personas que están cobrando ayudas, ampliando un poco más el dinero de lo que perciben pero generando empleo.

8) Que las personas trabajadoras de la Agencia de Empleo y Desarrollo Local acudan más a la calle a visitar a las empresas y poder saber así qué perfiles profesionales se están demandando para establecer convenios con el sector empresarial.
9) Que se faciliten más licencias para adelantar los horarios de apertura de los locales nocturnos.

10) Habilitar un número telefónico para atender a las personas en cuanto a dudas del ERTE, situación de desempleo o cualquier otra cuestión relacionada.

11) Mantener la instalación de terrazas al aire libre, para que los empresarios puedan sacar a muchos trabajadores del ERTE y seguir manteniendo sus negocios.

12) Aprovechar la realización de muchos eventos en el municipio de San Cristóbal de La Laguna en streaming para profesionalizar esta labor, de forma que se contrate a personal para las grabaciones con profesionalidad y calidad en vez de ser grabados incluso con el móvil y con una calidad muy baja.

13) Desarrollo de un plan de ayudas a nuevas familias no acostumbradas al círculo de los Servicios Sociales.

14) Aumentar la sinergia entre la Universidad de La Laguna, el Ayuntamiento de San Cristóbal de La Laguna y las entidades del municipio para generar proyectos sociales y de empleo.

15) Generar formaciones en orientación laboral, en las cuales los sindicatos puedan colaborar, para que las personas trabajadoras sepan cuáles son sus derechos.

16) Elaborar una reforma laboral profunda que mejore la calidad del trabajo, aumente la tasa de natalidad y fomente la conciliación familiar. 



\section{Cultura}

1) Facilitar los Centros Ciudadanos y otros lugares públicos abiertos como sitios de ensayo y actuaciones para agrupaciones musicales y eventos culturales.

2) Apostar por eventos culturales seguros, proponiendo ferias donde se garantice la seguridad higiénico-sanitaria.

3) Crear un protocolo de seguridad con medidas anti COVID específico para los eventos musicales y culturales.

4) Incluir las dinámicas comunitarias al sector cultural.

5) Promover píldoras formativas y eventos culturales generados y gestionados por mujeres.

6) Protocolizar mediante normativas que regulen y faciliten el arte callejero.
7) Realizar un mapeo sobre los gustos musicales y culturales de la población para ofrecer una agenda cultural ajustada a la realidad y repartida de manera equitativa.

8) Contratar a empresas profesionales que aumenten la calidad de los eventos culturales en streaming y fortalecer dicho sector.

9) Aumentar la oferta de turismo cultural, vinculando el comercio con la cultura.

10) Favorecer la creación de centros de la cultura en todo el municipio de San Cristóbal de La Laguna.

11) Fomentar el conocimiento de la cultura local.

12) Llevar a cabo una digitalización de las actividades y archivos culturales. 


\section{Seguridad Ciudadana}

1) Reforzar la vigilancia en las calles y en los establecimientos del municipio de San Cristóbal de La Laguna para el buen cumplimiento de las medidas higiénico-sanitarias.

2) Realizar campañas de concienciación sobre la importancia de la seguridad ciudadana en tiempos de pandemia dirigidas a la ciudadanía.

3) Endurecer las multas a quienes no cumplen con las medidas anti COVID-19.

4) Mantener las recomendaciones ofrecidas por Protección Civil a través de la megafonía de los coches.

5) Instalar dependencias policiales permanentes en los barrios en zonas de posible acumulación de personas.
6.) Establecimiento de un servicio de asesoramiento legal dentro de la Policía donde la ciudadanía pueda aclarar diferentes aspectos sobre las medidas de seguridad y la normativa ciudadana.

7) Necesidad de un asesoramiento de prevención de riesgos laborales para la Policía del municipio.

8) Creación de un equipo multidisciplinar coordinado entre los inspectores autonómicos y municipales, la Policía Local y los Servicios Sociales.

9) Realización de cribados COVID-19 al personal policial local de manera mensual (1).

10) Crear un servicio de denuncia ciudadana anónima en torno al incumplimiento de las medidas anti COVID.

11) Emitir la normativa de restricciones y de seguridad ciudadana en formatos más sencillos y cortos que el Boletín Oficial de Canarias. 


\section{Deporte}
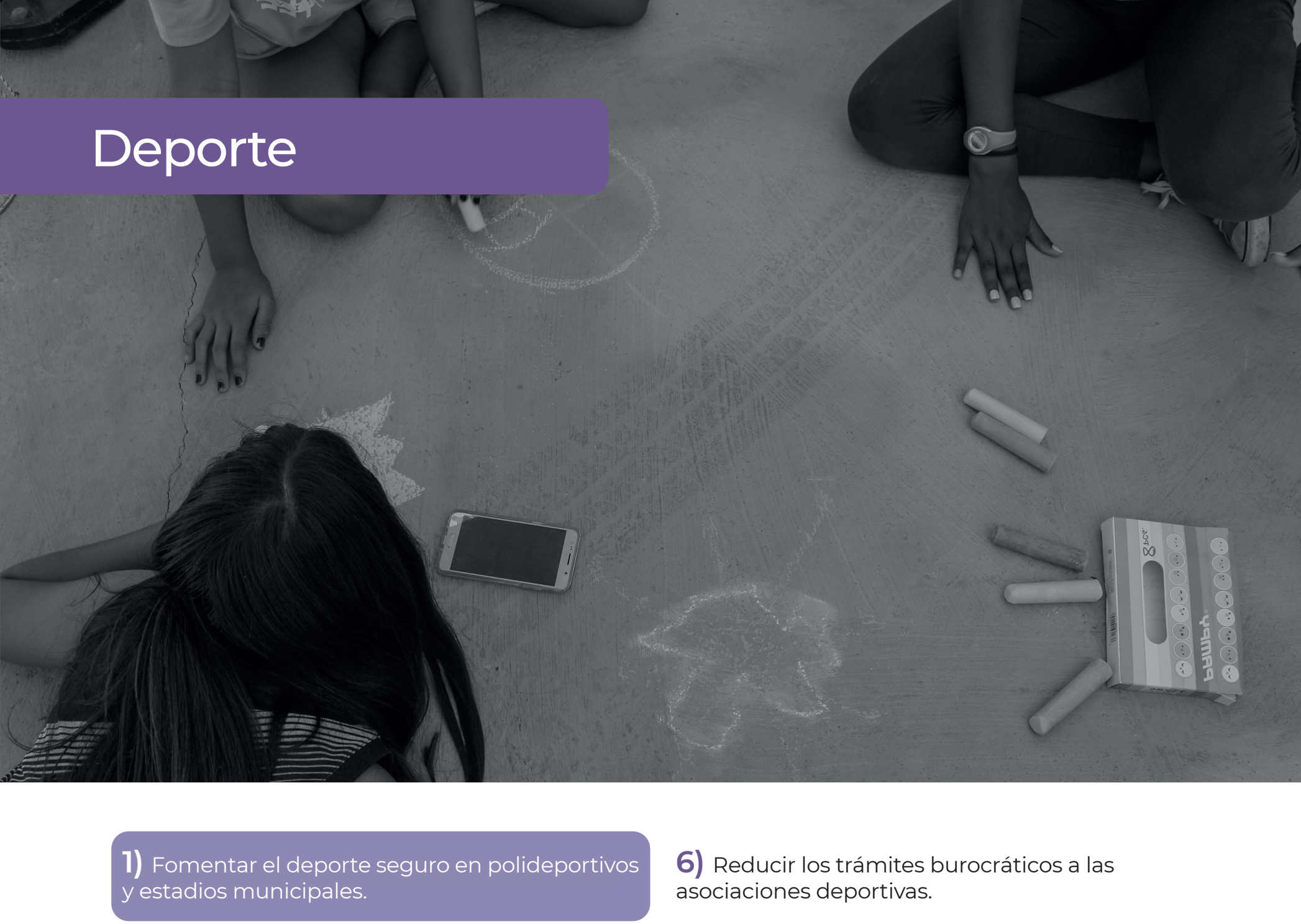

1) Fomentar el deporte seguro en polideportivos

2) Coordinación entre el Ayuntamiento de San Cristóbal de La Laguna y el Organismo Autónomo de Deportes para supervisar las medidas de seguridad e higiene en los campos de fútbol.

3) Crear normas públicas claras para el deporte al aire libre.

4) Mantener la limpieza y desinfección de espacios deportivos de manera periódica.

5) Implantar una buena red de carriles y aparcamientos de bicicletas en el municipio de San Cristóbal de La Laguna que fomente su uso como modo de transporte.
6) Reducir los trámites burocráticos a las asociaciones deportivas.

7) Repartir los espacios deportivos disponibles de manera equitativa.

8) Mejorar la coordinación entre las diferentes instituciones públicas a la hora de comunicar las medidas higiénico-sanitarias relacionadas con el deporte. 



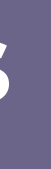 \\ Cont \\ Conclusi es}

Conclusiones

.

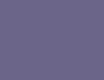

C)

(

P

.

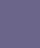

(1)

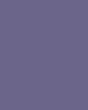

(

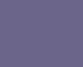

(

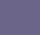



(3)

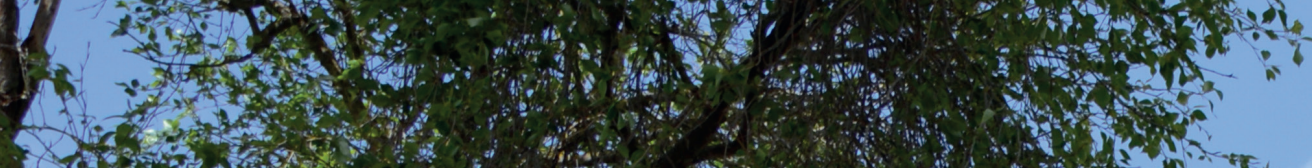

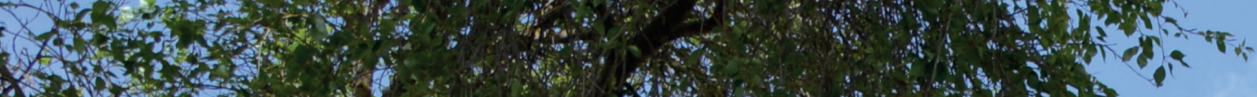
3.t.

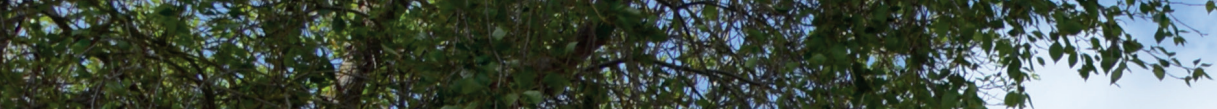

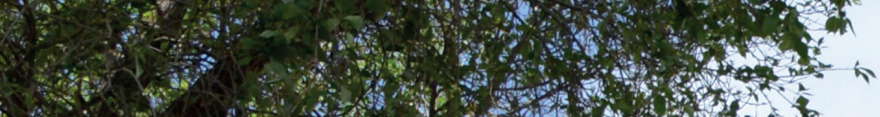

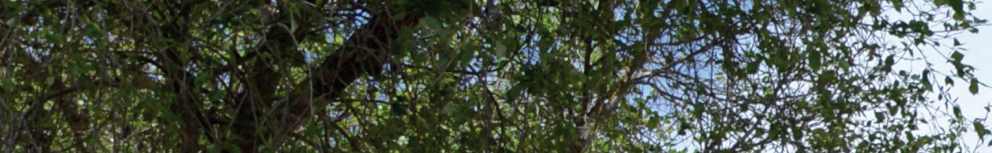

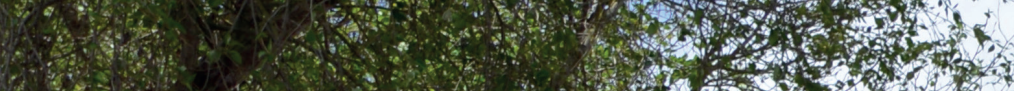

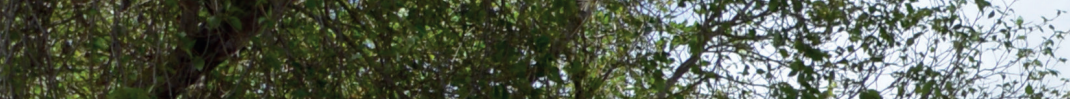

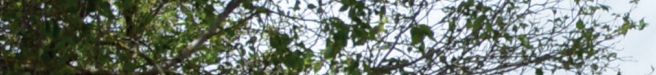

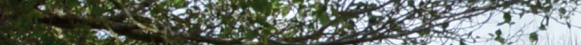

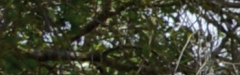

n.t.

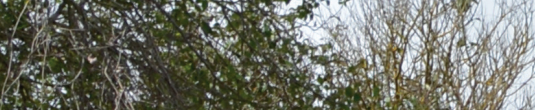

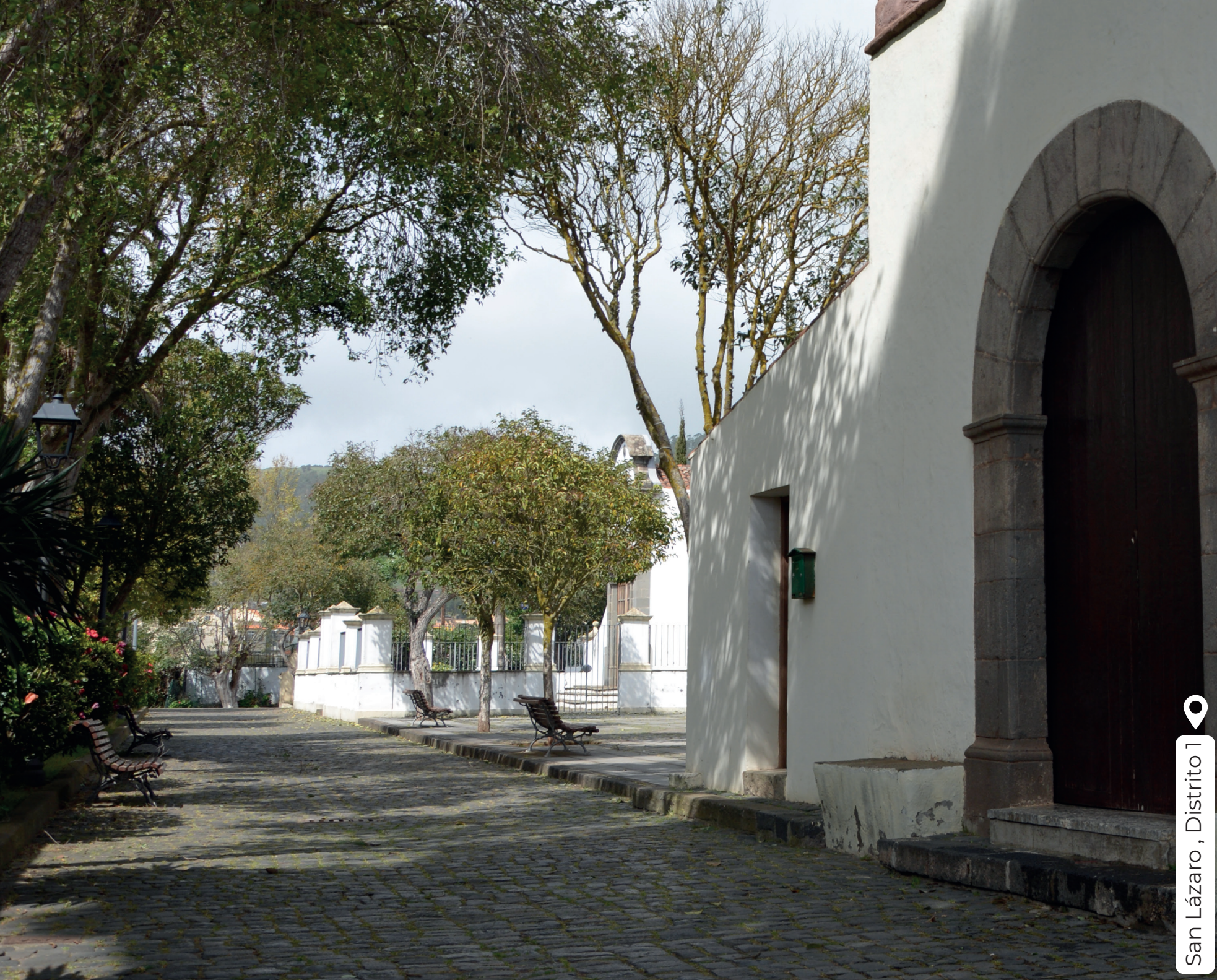


El desarrollo del Proceso de Audición vinculado con el Proyecto Comunidad y su resultado en forma de Monografía Comunitaria, titulada "La COVID-19 en San Cristóbal de La Laguna: una mirada desde la comunidad", ha constituido un ambicioso ejercicio de escucha a la comunidad lagunera que se ha resuelto con una importante participación de sus diferentes protagonistas (376 personas, 217 entidades escuchadas), recogiendo, en buena medida, las diferentes realidades socioterritoriales de un municipio extenso y heterogéneo. El enfoque metodológico aplicado, así como su continua revisión y adaptación a las circunstancias surgidas durante su elaboración, permiten aseverar que los resultados obtenidos son rigurosos y representativos de los discursos existentes. A ello se debe añadir la dedicación y competencia en su labor del amplio conjunto de personas implicadas, desde las que conformaron el equipo profesional, hasta las que se sumaron de manera voluntaria durante las distintas fases del proceso.

Un rigor que sustenta una investigación subjetiva y particular del equipo de trabajo, con enfoque comunitario, en base a la amplia esfera de análisis (impactos, expectativas, aprendizajes, conflictos, iniciativas y propuestas) ya mencionada en la introducción. Los datos de esta investigación, que son públicos, numerosos y diversamente ricos, pueden ser utilizados por organizaciones interesadas que puedan realizar nuevas explotaciones y/o abrir otras líneas de estudio que aporten más conocimiento sobre la etapa inédita que se ha vivido.

Cabe recordar que la finalidad de una Monografía Comunitaria es aportar un conocimiento compartido sobre una realidad determinada, en este caso, el impacto de la COVID-19 en San Cristóbal de La Laguna. Y de ahí, obtener una imagen más clara sobre lo que se considera el punto de vista y/o el interés general; mostrando de manera organizada aquello que está más presente en la mayor parte de las personas que estudian, trabajan o residen en el municipio y verbalizan en sus discursos.

Desde la perspectiva de los impactos, tras un año de permanencia de la pandemia causada por el virus SARS-CoV-2, se piensa más en el presente que en el futuro: los impactos pesan sobre las expectativas. La pérdida de las relaciones y sus múltiples implicaciones en la permanente construcción de la sociedad, se manifiesta como el mayor impacto de la COVID-19, seguido del binomio Salud-Economía, a pesar de ser éstos últimos los ámbitos que más han concentrado y polarizado los diferentes modelos de gestión de la pandemia. Atendiendo a las dimensiones analizadas, surgen diversos escenarios posibles 
según la correlación encontrada entre los impactos positivos y negativos. Un impacto negativo alto y un escaso impacto positivo, como es el caso de las dimensiones Economía, Ocio y Espacios públicos, sugiere la necesidad de una mejor respuesta por parte de la comunidad. Mientras que en otras dimensiones como la Sociedad, aún a pesar de concentrar los mayores impactos negativos, registra también los mayores impactos positivos, es decir, la comunidad parece haberse resarcido, no sin dificultades, de parte de los problemas que la asediaron durante los primeros momentos de la pandemia.

Desde la perspectiva de las iniciativas desarrolladas, éstas se focalizaron en mayor medida en la adaptación de protocolos y procedimientos para el desarrollo de proyectos, programas y servicios ya existentes, más que en la generación de nuevas iniciativas. No obstante, aquellas iniciativas que se llevaron a cabo de manera original para enfrentar la pandemia, se caracterizaron por ser, en su mayoría, de carácter individual y por ofrecer una respuesta inmediata a las necesidades más básicas. Las iniciativas que requirieron la conformación de una estructura para su realización e implicaron la organización de un grupo más amplio de personas no fueron las más habituales, y además, las que surgieron no se mantuvieron en el tiempo.

Desde la perspectiva de las expectativas a futuro, predominan ligeramente las positivas frente a las negativas. Las expectativas a futuro son más positivas si hacen referencia a aquellas dimensiones sociales que conllevan efectos inmediatos, porque su vuelta a la cotidianeidad se vincula con la relajación o desaparición de las medidas sanitarias de prevención de contagios (Ocio, Cultura, Deporte, Espacios públicos, Sociedad, Educación, Salud). Sin embargo, las expectativas son más negativas en aquellas dimensiones en las que la recuperación de la situación prepandémica conlleva más tiempo, y además, de manera presumible, será necesaria la concurrencia de más aspectos que únicamente la vuelta a la normalidad (Economía y Empleo).

Desde la perspectiva de los conflictos, cabe destacar que aún quedan conflictos por resolver y corresponden, en su mayoría, a la esfera de lo social. Una esfera que requiere de la complicidad de muchas personas de la comunidad para resolverlos, pero, en especial, de las administraciones públicas, como garantes del interés general y de la preservación de los derechos fundamentales de la ciudadanía. Con todo, el impacto en las personas ha estado contenido por la capacidad de respuesta de la comunidad, en especial de los servicios públicos (educación, servicios sociales, salud, seguridad ciudadana, etc.). Nunca han sido suficientes para ofrecer una alternativa adecuada a todas las situaciones de vulnerabilidad que se han generado, pero han sido capaces de evitar situaciones extremas, por lo menos, hasta el momento. 
Las personas profesionales de la educación, la sanidad, los servicios sociales y la seguridad ciudadana, con la complicidad de las entidades e integrantes de la comunidad, han soportado y gestionado de manera positiva el envite que supuso la irrupción inesperada de la COVID-19. A pesar de encontrarse bastantes dificultades en un primer momento, resolvieron muchos de los conflictos que se generaron, obteniendo valiosos aprendizajes que les han permitido gestionar adecuadamente la compleja situación que se ha producido a medida que pasaba el tiempo.

La principal damnificada de la COVID-19 es la sociedad y las relaciones entre sus componentes, particularmente durante el confinamiento domiciliario obligatorio. Pese al contexto general, se constatan ejemplos más específicos en los que los vínculos se han intensificado, aunque con menor capacidad de aportación a la dinámica general. Ejemplo de esta situación son los grupos a favor o en contra de la relajación de las decisiones sanitarias, del uso de espacios públicos, de las vacunas, de las medidas administrativas, entre otros, que dificultan la gestión y resolución de conflictos. Requieren además la concentración de esfuerzos en la generación de espacios de diálogo, que permitan identificar objetivos comunes y organizarse para conseguirlos.

Los conflictos sociales derivados de la instauración de medidas de prevención de contagios, implican a una parte de la comunidad que no las considera necesarias, mientras que otra parte se ve concernida por la falta de cumplimiento de los primeros. Esto es un ejemplo claro de que la gestión es mejorable, pues no supera la dualidad exceso-defecto y evidencia una falta de organización y jerarquía competencial. La gestión del conflicto se ha trasladado a la sociedad, en muchas ocasiones sin tener las herramientas ni la capacidad para abordarlo. Desde la perspectiva de los aprendizajes, se puede aprender de aquellos grupos que han gestionado sus conflictos de manera adecuada, y sobre todo, de los que han conseguido resolverlos. Ejemplos de esto han sido los/as profesionales de la Salud o de la Educación, las personas que se han ocupado de mantener la educación de sus hijos e hijas desde los domicilios, las personas que han cuidado de las más vulnerables, las personas que han preservado la paz social o las personas que han mantenido las relaciones con su entorno.

Las crisis suelen ofrecer contextos de oportunidad para la sociedad, siempre que las personas puedan ser capaces de aprender y replicar los elementos de más valor. Particularmente aquellos que se construyen de manera colectiva y desde una mirada positiva, y que, al mismo tiempo, se alejan de las prácticas que solo benefician intereses concretos e individuales. Es necesario entonces apreciar, e incluso sistematizar para inspirar y propagar, lo que se ha hecho bien para la comunidad y por la comunidad. E incluso, con la comunidad. 
Comunidad ha supuesto un importante esfuerzo colectivo para seguir construyendo comunidad incluso en una etapa de máxima incertidumbre y complejidad. Ahora cuando ya se constata una mejoría sustancial de la situación pandémica y se va retomando una cierta normalidad, constituye una oportunidad, y a la vez una ventaja competitiva, disponer de muchas de las claves de la experiencia colectiva compartida, sobre todo a través de la voz de sus protagonistas.

Es fundamental entonces su conocimiento y mayor difusión posible, para que la comunidad recuerde dicha experiencia, obtenga y aplique, si cabe, los aprendizajes obtenidos, particularmente aquellos que la fortalecen. Con ese objetivo se comenzó este trabajo, que asimismo persigue poner las bases para activar procesos comunitarios de largo recorrido, conscientes que acabarán conformando una sociedad mejor organizada y más resiliente a la adversidad; también más solidaria e incluyente, como corresponde por su trayectoria al municipio lagunero. 


\section{La COVID-19 en San Cristóbal de La Laguna:}

\section{Desde la perspectiva de los impactos}

Tras un año de permanencia de la COVID-19 se piensa más en el presente que en el futuro:

los impactos pesan sobre las expectativas.
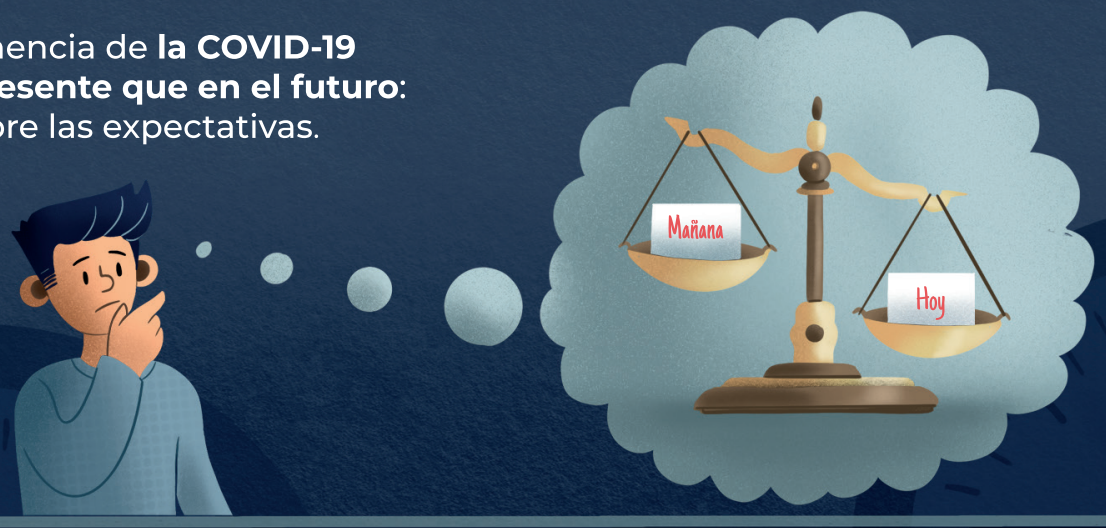

2 La pérdida de las relaciones y

$L$ sus múltiples implicaciones en la permanente construcción de la sociedad, se manifiesta como el mayor impacto de la COVID-19.
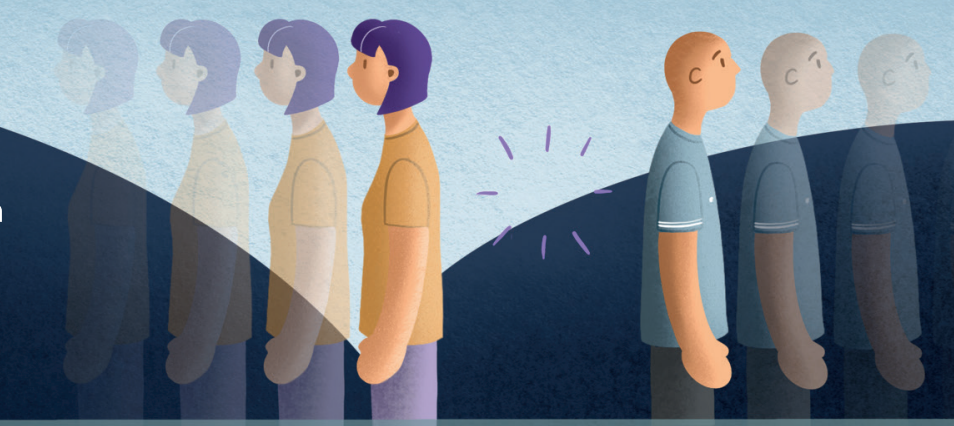

Entre los principales impactos negativos se encuentra la dicotomía Salud-Economía, reflejándose el discurso que ha concentrado y polarizado los diferentes modelos de gestión de la pandemia.

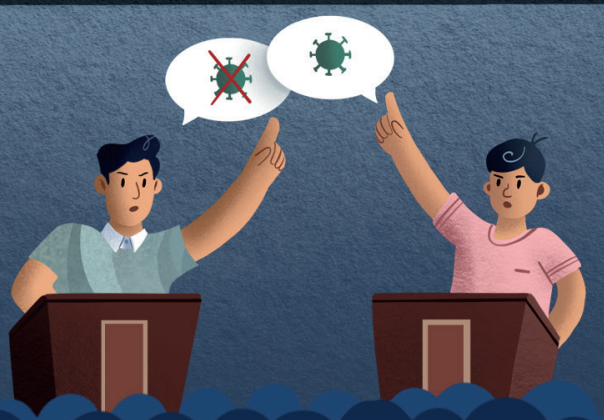

Atendiendo a las dimensiones, la correlación entre impactos positivos y negativos plantea los escenarios más complejos. Un impacto negativo alto y un escaso impacto positivo, como es el caso de la Economía, el Ocio y los Espacios públicos, muestra unas dimensiones que no han encontrado una mejor respuesta desde la comunidad.
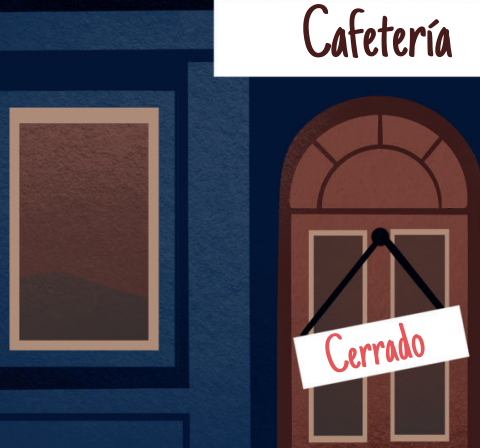


\section{Desde la perspectiva de las iniciativas desarrolladas}

Las iniciativas se focalizaron en mayor medida en la adaptación de protocolos y procedimientos para el desarrollo de proyectos, programas y servicios ya existentes, más que en la generación de nuevas iniciativas.

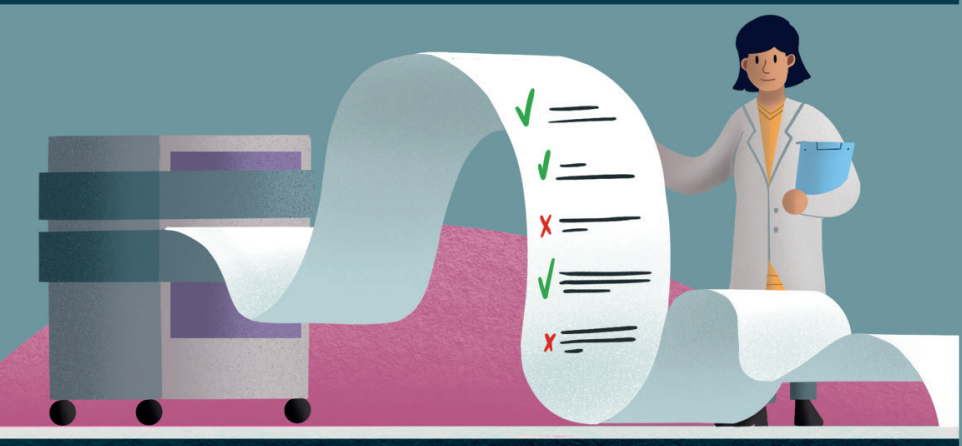

Las iniciativas de carácter individual y de respuesta inmediata para resolver necesidades básicas, destacaron sobre las iniciativas que implicaban un grado mayor de organización a partir de grupos de personas con una estructura para su desarrollo y que se mantuviera en el tiempo

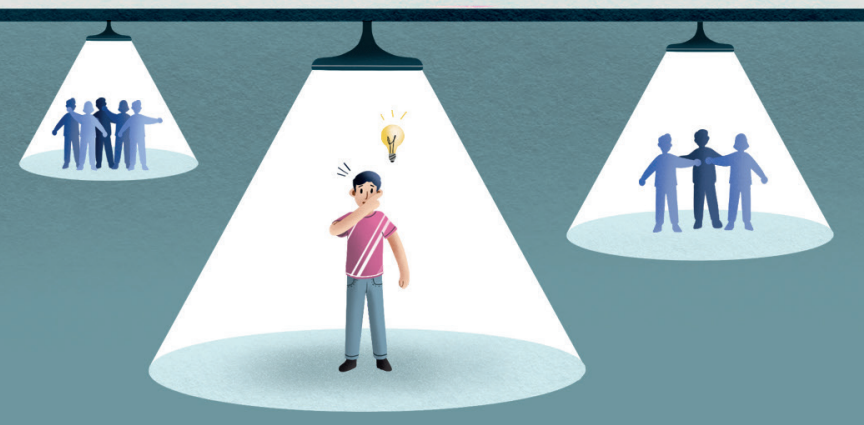

\section{Desde la perspectiva de las expectativas}

Las expectativas a futuro son más positivas si hacen referencia a aquellas dimensiones sociales que conllevan efectos inmediatos, porque su vuelta a la cotidianeidad se vincula con la relajación o desaparición de las medidas sanitarias de prevención de contagios (Ocio, Cultura, Deporte, Espacios públicos, Sociedad, Educación, Salud).

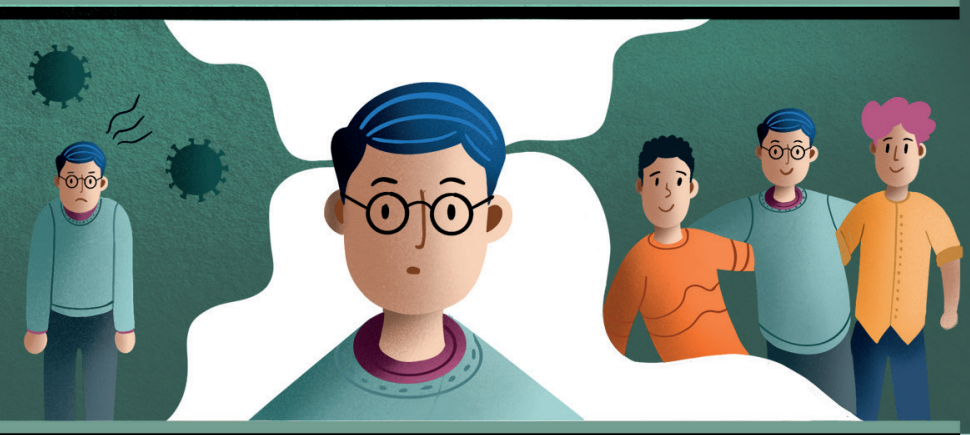

Las expectativas son más negativas en aquellas dimensiones en las que la recuperación de la situación prepandémica conlleva más tiempo, y además, de manera presumible, será necesaria la concurrencia de más aspectos que únicamente la vuelta a la normalidad (Economía y Empleo).

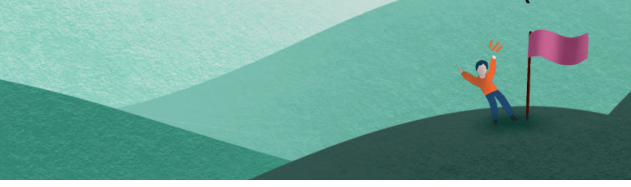




\section{Desde la perspectiva de los conflictos}

Quedan conflictos que resolver y corresponden al ámbito de lo social, que requiere de la complicidad de muchas personas de la comunidad para resolverlos, pero, en especial, de las administraciones públicas, como garantes del interés general y de la preservación de los derechos funda mentales de la ciudadanía.
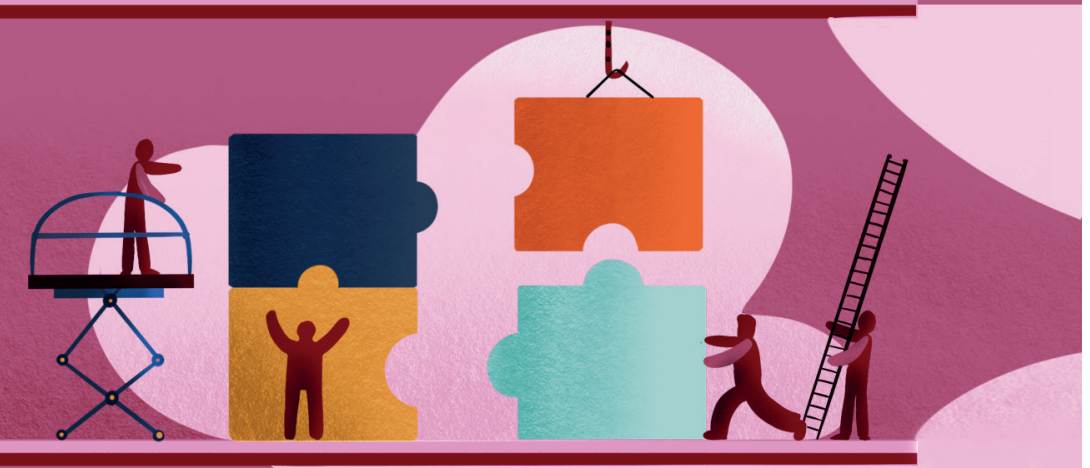

El impacto en las personas ha estado contenido por la capacidad de respuesta de la comunidad, en especial, de los servicios públicos (educación, servicios sociales, salud, seguridad ciudadana, etc.). Nunca han sido suficientes para dar una respuesta adecuada a todas las situaciones de vulnerabilidad que se han generado, pero han sido capaces de evitar, situaciones mucho peores.
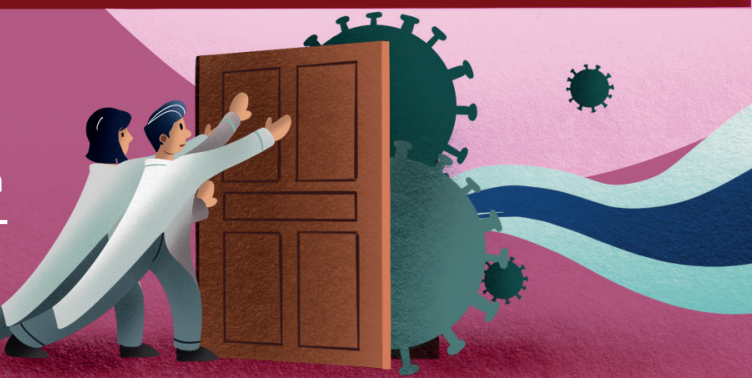

4

2 Las personas profesionales de la educación, la sanidad, los servicios sociales y la seguridad ciudadana, con la complicidad de las entidades y personas de la comunidad, han soportado y gestionado de manera positiva el envite que supuso la irrupción sobrevenida de la COVID-19.

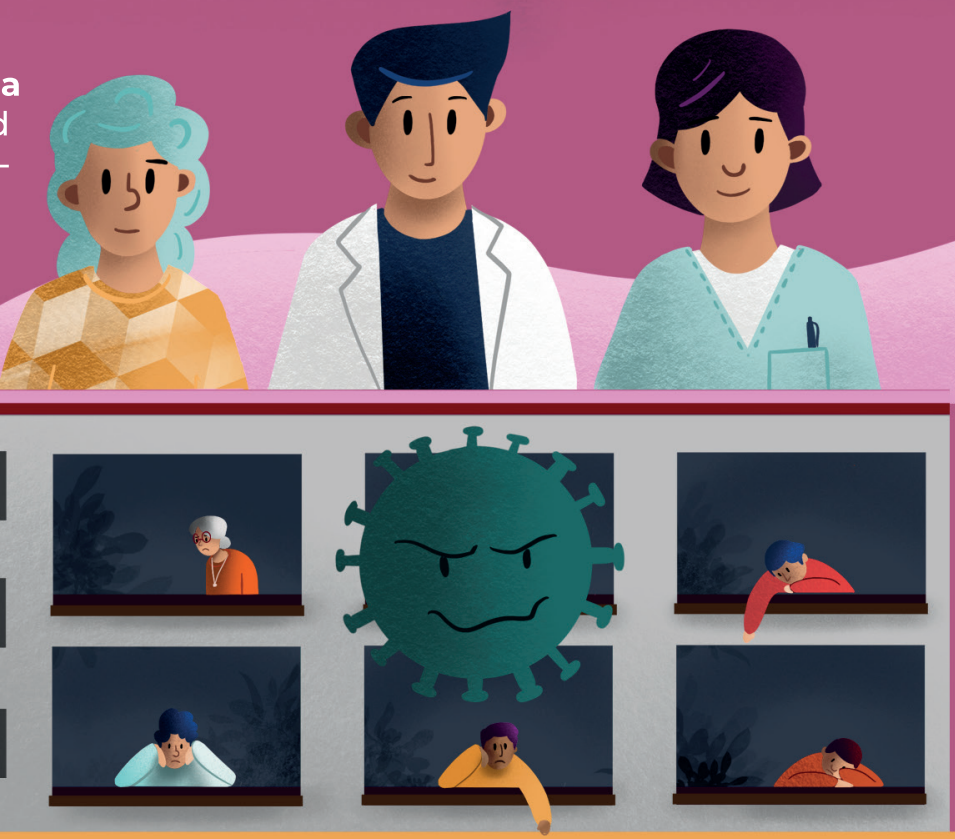

\section{Desde la perspectiva de los aprendizajes}

Se puede aprender de aquellos grupos que han gestionado sus conflictos de manera adecuada y han conseguido resolverlos en el mejor de los casos. Ejemplos han sido los profesionales de la Salud o de la Educación, las personas que se han ocupado de mantener la educación de sus hijos e hijas en los domicilios, las personas que han cuidado de las personas más vulnerables, las personas que han preservado la paz social o las personas que han mantenido las relaciones con su entorno, a pesar de la distancia.

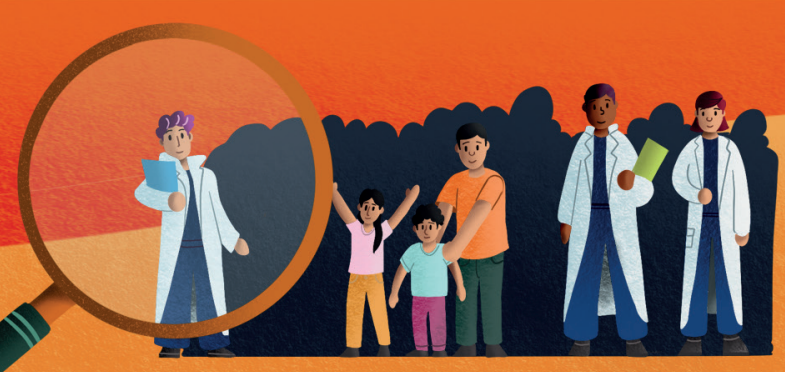


Comunidad ha supuesto un importante esfuerzo colectivo para seguir construyendo comunidad incluso en una etapa de máxima incertidumbre y complejidad. Ahora cuando ya se constata una mejoría sustancial de la situación pandémica y se va retomando una cierta normalidad, constituye una oportunidad, y a la vez una ventaja competitiva, disponer de muchas de las claves de la experiencia colectiva compartida, sobre todo a través de la voz de sus protagonistas.

Es fundamental entonces su conocimiento y mayor difusión posible, para que la comunidad recuerde dicha experiencia, obtenga y aplique, si cabe, los aprendizajes obtenidos, particularmente aquellos que la fortalecen. Con ese objetivo se comenzó este trabajo, que asimismo persigue poner las bases para activar procesos comunitarios de largo recorrido, conscientes que acabarán conformando una sociedad mejor organizada y más resiliente a la adversidad; también más solidaria e incluyente, como corresponde por su trayectoria al municipio lagunero. 


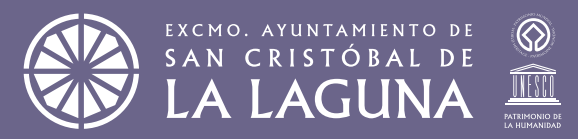
OMunidad
45 Universidad
CABHtDU 